\title{
O USO DA INTERNET POR DOCENTES DA ÁREA DE SAÚDE PÚBLICA NO BRASIL
}

\author{
ANGELA MARIA BELLONI CUENCA
}

Tese apresentada ao Programa de PósGraduação em Saúde Pública da Faculdade de Saúde Pública da Universidade de São Paulo para obtenção do título de Doutor em Saúde Pública

Área de concentração:

Saúde Materno-Infantil

Orientadora:

Profa. Dra. Ana Cristina D'Andretta Tanaka

São Paulo

2004 
Autorizo, exclusivamente para fins acadêmicos e científicos, a reprodução total ou parcial desta tese, por processos fotocopiadores.

Assinatura:

Data: 
Para Francisco e Teresinha, queridos pais, exemplos de vida que sempre procurei seguir.

Para Carina, Gustavo, Letícia - especialmente Wagner - e toda minha família, dos quais me privei de bons momentos de convívio durante o tempo dedicado a esta pesquisa. 


\section{AGRADEÇO ESPECIALMENTE}

A todos os docentes que, mesmo repletos de atividades, pacientemente, submeteramse a responder o questionário desta pesquisa. Sem tal ajuda essa tese seria inviável.

Ao apoio constante de toda a equipe da Biblioteca da Faculdade de Saúde Pública ao meu trabalho durante esses anos. Sou devedora a meus colegas que vem trabalhando comigo durante todos esse anos na Biblioteca.

A ajuda inestimável dos amigos que não se furtaram de gastar seu tempo comigo, durante o curso, nas diversas fases da tese e, principalmente na retaguarda de minhas atividades acadêmicas e da Biblioteca. Novamente, eu digo obrigado. Aqui estão os seus nomes:

Eidi Raquel Franco Abdalla

Lea Maria Belloni Jorge

Maria do Carmo Avamilano Alvarez

Maria Lúcia Evangelista de Faria Ferraz

Sonia Garcia Gomes Eleutério

Suely Assunção de Olim Santos

Teodora (Dora) Pinheiro

Especialmente, quero agradecer a uma equipe imbatível no quesito informática, sem a qual o questionário eletrônico e a tabulaçao dos dados seriam bem mais complicados... 
Daniel Marucci

Fernão Dias de Lima

Wagner Cuenca

Sou devedora a minhas amigas e colegas que me inspiraram e incentivaram minha carreira acadêmica e com as quais aprendi a maior parte do que eu sei sobre comunicação científica.

Profa. Dra. Daisy Pires Noronha

Profa. Dra. Maria Teresinha Dias de Andrade

A bibliotecária (e grande amiga) Jussara Long incansável na ajuda para coleta de dados e no otimismo que tem me ensinado.

A todos que, de alguma forma, me ajudaram com estímulo e amizade no decorrer desta fase da minha vida. 
In memorian

Profa. Dra. Keiko Ogura Buralli, minha primeira e enstusiasta orientadora do doutorado. 
“Um dos males destes tempos é a multiplicidade de livros (...) não conseguimos digerir a abundância de matéria inútil (...) que, todos os dias, é gerada e despejada no mundo."

(Depoimento de um estudioso, em 1613) 
Cuenca AMB. O uso da internet por docentes da área de saúde pública no Brasil. São Paulo; 2004. [Tese de Doutorado - Faculdade de Saúde Pública da USP]

\section{RESUMO}

Objetivo. O objetivo principal desta tese é conhecer a influência da internet nas atividades acadêmico-científicas da comunidade brasileira de docentes da área de saúde pública. Métodos. Estudo transversal, centrado na opinião do usuário sobre o uso e a influência da internet na prática de ensino e pesquisa no âmbito acadêmico. A população do estudo constitui-se de 237 docentes vinculados aos programas de pósgraduação em saúde pública, nos níveis mestrado e doutorado, das instituições brasileiras de ensino superior cadastradas no sistema CAPES (Fundação Coordenação de Aperfeiçoamento de Pessoal de Nível Superior) em 2001. Para a obtenção dos dados, optou-se pelo uso de questionário auto-aplicável preenchido via web e encaminhado via correio eletrônico, com internet disponibilizada em servidor UNIX. Para os que não responderam o instrumento eletrônico, foram enviados questionários impressos. Resultados. A taxa de retorno do questionário foi de $63,7 \%$. O uso da internet foi apontado por $94,9 \%$ dessa comunidade, sendo o correio eletrônico $(96,9 \%)$ e a web $(91,1 \%)$ os recursos mais utilizados. A influência mais marcante da internet foi na comunicação entre os docentes, principalmente para o desenvolvimento de pesquisas, propiciando mais colaboração com colegas de 
instituições nacionais e estrangeiras. Considerou-se que a atividade acadêmica de busca de informação bibliográfica e de textos completos foi muito beneficiada pela utilização da internet. Quanto à divulgação de resultados de pesquisa, ainda há predominância dos formatos impressos, principalmente em artigos de periódicos de circulação nacional. Os docentes que declararam não utilizar a internet justificaram o fato argumentando falta de motivação, expressada em questões de caráter subjetivo, como a resistência em usar novas tecnologias, a falta de tempo para usar a internet e a facilidade de conseguir de seus colegas o material de que precisam. Conclusões. Os dados mostram que a internet influenciou o trabalho dos docentes e afeta o ciclo da comunicação científica, principalmente na rapidez de recuperação de informações. Entre os docentes, há forte tendência em eleger a comunicação entre pesquisadores como a etapa que mais mudou desde o advento da internet no mundo acadêmicocientífico brasileiro.

Descritores: Saúde pública. Comunidade acadêmica. Programas de pós-graduação. Pesquisadores. Docentes. Redes eletrônicas. Tecnologia da informação. Universidades. World Wide Web. Correio eletrônico. Internet. 
Cuenca AMB. Internet use by professors of the public health area in Brazil. São Paulo; 2004. [Doctoral dissertation - Faculdade de Saúde Pública da USP]

\section{ABSTRACT}

Objective. The main objective of this study is to investigate the influence of the Internet on the academic-scientific activities of Brazilian professors of the public health area. Method. Transversal study centered on the user view about influences of the internet on the academic teaching and research. The study's core was constituted by 237 professors from public health post-graduation programmes of higher education institutions in Brazil, in master's and doctoral levels, registered in the CAPES System (Brazilian Ministry of Education's foundation for the qualification of higher education professors) in the year 2001. Data were collected by means of a self-applicable questionnaire that professors answered and sent through the web (by electronic mail), Internet access via a UNIX server. Those who did not answer the electronic instrument received printed questionnaires. Results. The return rate of the questionnaires was $63.7 \%$. The great majority of the population (94.9\%) answered that they use the Internet, the electronic mail (96.9\%) and the web (91.1\%) were the most used resources. The strongest influence of the Internet on scientific communication in the public health area concerns communication among professors, with the aim of developing research, enabling greater collaboration with colleagues both from Brazilian 
and foreign institutions. Searches for bibliographic references and for full texts were considered academic activities that benefited a lot from Internet use. As for release of research results, printed formats still prevail, mainly articles published in national circulation journals. The professors who stated that they do not use the Internet argued that the reason for this is lack of motivation, expressed through subjective questions, such as resistance to use new technologies, lack of time to use the Internet and facility of obtaining what they need from their colleagues. Conclusions. Data show that the Internet influenced the academic's work and has been affecting the cycle of scientific communication, mainly due to the high speed with which information can be recovered. Communication among researchers seems to be the stage that changed the most since the advent of the Internet in the Brazilian academic-scientific world.

Keywords: Public Health. Academic community. Post-graduation programmes. Researchers. Professors. Electronic networks. Information technology. Universities. World Wide Web. Electronic mail. Internet. 


\section{ÍNDICE}

1. INTRODUÇÃO 1

1.1 A tecnologia da informação na comunidade acadêmico-científica 3

1.2 Definindo a internet 8

$\begin{array}{ll}\text { 1.2.1 Números da internet no Brasil } & 14\end{array}$

$\begin{array}{ll}1.3 \text { A comunicação do conhecimento científico } & 16\end{array}$

1.3.1 Os intermediários na comunicação científica e a tecnologia da 20 informação: a editoria científica

1.3.2 Os intermediários na comunicação científica e a tecnologia da 23 informação: bibliotecas e sistemas de informação

1.4 A literatura científica sobre a internet 26

1.5 Sobre a proposta do presente estudo 29

2. OBJETIVOS 31

3. MÉTODOS 32

3.1 Universo de estudo 32

$\begin{array}{ll}3.2 \text { Coleta de dados } & 37\end{array}$

$\begin{array}{ll}\text { 3.2.1 Instrumento de coleta de dados } & 37\end{array}$

3.2.2 Procedimento de envio dos questionários 40

3.3 Análise estatística $\quad 42$

3.4 Questões éticas $\quad 42$

4. RESULTADOS E DISCUSSÃO 43

4.1 Quanto ao emprego do questionário via internet 43

4.1.1 Forma de envio dos questionários $\quad 45$

4.1.2 Escolha pelo impresso ou eletrônico $\quad 47$

4.2 Caracterização da população estudada 49

4.3 Uso da internet pela comunidade estudada 60

4.3.1 Uso dos recursos da internet 61

4.4 Não usuários da Internet da comunidade estudada 63

4.5 Fatores associados ao uso da internet 65

4.5.1 Uso da Internet e faixa etária e experiência acadêmica 65 
4.5.2 Uso da internet e área do conhecimento

67

4.5.3 Uso da Internet e regime de trabalho e distribuição do tempo para 69 atividades acadêmico-científicas

$\begin{array}{ll}\text { 4.6 A internet e a comunicação entre os docentes } & 71\end{array}$

4.7 Divulgação no processo da comunicação científica com a internet $\quad 74$

4.8 A web e a busca e obtenção da informação 77

4.9 Influência da internet nas atividades da pesquisa científica 82

4.10 Influência da internet nas atividades de ensino acadêmico 85

4.11 Barreiras e expectativas de uso da internet 88

4.12 Opiniões conclusivas dos docentes sobre a internet 100

5. CONCLUSÕES E CONSIDERAÇÕES FINAIS 108

6. REFERÊNCIAS 114

ANEXOS

Anexo 1 - Programas de Pós-Graduação em Saúde Coletiva, $\quad$ A1 credenciados na CAPES- 2001.

Anexo 2 - Questionário eletrônico (Disquete) A2

Anexo 3 - Questionário impresso $\quad$ A3

Anexo 4 - Titulação dos docentes dos Programas de Pós-Graduação em A12 Saúde Coletiva, 2002, no Mestrado

Anexo 5 - Titulação dos docentes dos Programas de Pós-Graduação em A13 Saúde Coletiva, 2002, no Doutorado

Anexo 6 - Especialidades temáticas, segundo a percepção do docente, $\quad$ A14 não incluídas no DeCS

Anexo 7 - Opiniões dos docentes sobre a internet 


\section{INTRODUÇÃO}

Pela primeira vez na história, milhões de pessoas têm acesso instantâneo a grandes quantidades de informações, de qualquer lugar e em qualquer horário. Cada vez mais a sociedade depende de sistemas automatizados para controle, armazenamento, distribuição e acesso a dados que são gerados por milhares de processos inerentes às atividades de praticamente todos os ramos do conhecimento, constituindo-se em desafio sem precedentes para os profissionais das tecnologias da informação. Nesse cenário, as redes eletrônicas, produtos das novas tecnologias da informação, são cada vez mais aprimoradas para suprir as demandas de transmissão e armazenamento de informações, sendo a internet seu principal produto. Esta tem sido apontada como o motivo principal dessa aceleração e crescimento da comunicação.

O fato é que a sociedade vive hoje com a instantaneidade das comunicações, com um mundo menor, com a substituição do papel pela virtualidade das publicações eletrônicas, situação cujo impacto somente será conhecido em algumas décadas. 
Os avanços tecnológicos na informática têm tido reflexos também no comportamento da comunidade científica quanto à produção do conhecimento, especialmente nas universidades, pioneiras na utilização de redes eletrônicas, gerando uma necessidade cada vez maior de atualização tecnológica (SIMON 1998). Essa necessidade afeta todos os envolvidos no processo de geração do conhecimento: quem usa, quem produz e quem trata a informação produzida.

O sistema de comunicação no mundo científico, parte integrante e indissociável do processo de produção da ciência, abrange todas as atividades associadas à produção, à disseminação e ao uso da informação, desde o momento em que o cientista concebe uma idéia para a sua pesquisa até aquele em que seus resultados são aceitos pela comunidade científica como um novo conhecimento (GARVEY 1979). Esse novo conhecimento científico, por sua vez, gera informação que, reunida, organizada e disseminada pelos sistemas de informação e bibliotecas, tem sua relevância julgada pelo público, que a utilizará para promover o desenvolvimento (BARRETO 1998). Esse ciclo que se perpetua é estabelecido entre o pesquisador que detém o saber acumulado, os intermediários (editoras, bibliotecários, cientistas da informação) que divulgam a informação e seu público, representado principalmente pelos pares e comunidades acadêmicas que são receptores e produtores da informação científica.

É indiscutível que a inserção das tecnologias da informação, em especial a internet, influenciam a comunicação científica, principalmente quanto ao tempo necessário para que seu ciclo se renove. Ou seja, entre a produção da informação e sua assimilação pelo pesquisador, o espaço de tempo pode tornar-se praticamente 
zero, quando, há até algum tempo, dava-se em cerca de dois ou três anos (MARCHIORI 2002, MEADOWS 1999).

Além do tempo, as novas tecnologias de informação modificam a forma como o pesquisador lê, escreve, pesquisa, apresenta seus trabalhos e obtém informações. Cabe ressaltar que as novas tecnologias da informação, principalmente as redes eletrônicas, não se restringem somente à idéia de uso de computadores e da telecomunicação, que convergem para uma base digital e possibilitam um mesmo canal de informação, mas às reais modificações que a tecnologia trouxe ao ambiente da informação: "um novo elaborar para o conhecimento, modificando suas configurações no tempo e no espaço". (BARRETO 2002, p.12).

Essas redes tornam visíveis as práticas particulares de cada área, com suas peculiaridades em relação aos padrões de comunicação que utilizam. Assim, os estudos sobre a comunicação por meio de redes eletrônicas podem comprovar todos esse fatos, além de verificar se a comunidade acadêmica está apta a usufruir desse novo modelo de comunicação virtual e determinar novos padrões de comunicação para as diversas áreas do conhecimento (HARRISON e STEPHEN, 1995).

\subsection{A tecnologia da informação na comunidade acadêmico-científica}

A atualização sobre novos conhecimentos é condição obrigatória para a comunidade acadêmico-científica desempenhar suas atividades de ensino e pesquisa. Dessa forma, as universidades têm sido as pioneiras e as maiores beneficiárias no uso das novas tecnologias da informação. Com a internet, bibliografias, bases de dados e textos completos tornaram-se mais acessíveis, permitindo à comunidade acadêmica 
uma atualização nunca antes pensada em termos de rapidez e eficiência no acesso e na obtenção de informação. A consulta pode ser feita em qualquer lugar, não mais somente nas bibliotecas, com acesso eqüitativo e simultâneo, em qualquer parte do mundo. Mais recentemente, artigos de vários periódicos especializados impressos têm similares eletrônicos na internet, beneficiando o pesquisador no árduo trabalho de localização e busca de artigos selecionados das bases de dados e bibliografias.

No ensino, a internet altera as modalidades de aprendizado, propiciando maior conhecimento da temática, mais eficiência no ensinar, maior comunicação entre docentes e melhor supervisão das atividades discentes (BRUCE 1995). As redes eletrônicas podem beneficiar a educação centrada no aprendiz, vislumbrando o ensino superior inserido em um sistema de abrangência mundial. Os professores, em vez de desenvolverem o conteúdo e transmiti-lo em sala de aula, poderão fazê-lo à longa distância, enfatizando suas habilidades de motivação e consultoria (CUNHA 2000). A internet pode oferecer novos métodos e ferramentas para um ensino mais amplo e melhor (FONTES 2001).

Nas atividades de pesquisa, a troca de informações pode ocorrer de forma virtual e em tempo real, permitindo discussões de resultados de pesquisa em vários locais e com mais colaboração de cientistas. O pesquisador engajado em redes e atualizado com as novas tecnologias tem mais facilidade de comunicação com seus pares, podendo participar de grupos nacionais e internacionais de pesquisa, além de ter a possibilidade de desenvolver um trabalho corporativo (CIANCONI 2001). Segundo CUNHA (2000), o pesquisador solitário do passado é substituído pelo grupo de pesquisa composto de especialistas de várias áreas do conhecimento. A rapidez na 
divulgação das pesquisas possibilita que o conhecimento circule de forma mais ágil e, da mesma forma, gere novas pesquisas (SOUZA 2003).

Em nota publicada na revista Nature, ALONSO e FERNANDEZ-JURIDIC (2002) atribuem a maior visibilidade da ciência brasileira à disponibilização de resultados de pesquisa em artigos na internet. Os autores divulgaram avaliação do impacto internacional de periódicos e concluíram que os fatores de impacto de cinco revistas brasileiras indexadas pelo ISI (Institute for Scientific Information) cresceram mais de 130\% desde sua inclusão na SciELO (Scientific Eletronic Library Online) [Biblioteca Científica Eletrônica em Linha]. A SciELO (www.scielo.br) disponibiliza gratuitamente textos completos de uma seleção de revistas científicas brasileiras, em diferentes áreas do conhecimento, visando à sua disseminação e à realização de uma base bibliográfica nacional para pesquisas bibliométricas e de impacto das citações (BIREME 2002). O projeto SciELO* foi desenvolvido no Brasil em 1997, mediante consórcio envolvendo a FAPESP (Fundação de Amparo à Pesquisa do Estado de São Paulo) e a BIREME (Centro Latino-Americano e do Caribe de Informação em Ciências da Saúde), e passou a contar, desde 2002, com o apoio do CNPq (Conselho Nacional de Desenvolvimento Científico e Tecnológico). Entre os demais produtos dessas parcerias, em 1999 também foi inaugurada a SciELO Saúde Pública, que cobre a área de saúde pública com periódicos da América Latina e Espanha.

É nesse contexto que se encontra o pesquisador brasileiro vinculado principalmente às universidades públicas. Estas, embora sejam pioneiras no uso das

\footnotetext{
*Informações sobre o Projeto SciELO obtidas no endereço http://www.scielo.org/model_pt.htm, disponível em maio de 2004.
} 
tecnologias de redes eletrônicas, detendo 91,3\% da produção científica do país (MEIS e col. 2003), ainda carecem de fortes investimentos para a criação e coordenação de redes eletrônicas de comunicação científica (ALONSO e FERNANDEZ-JURIDIC 2002).

No Brasil, onde a desigualdade entre ricos e pobres aumenta e os riscos da exclusão social são potencializados pelo distanciamento tecnológico da sociedade (CUNHA 2000), convive-se com o que há de mais sofisticado em termos de tecnologia, como acontece no ambiente das universidades, e, ao mesmo tempo, com situações de extrema exclusão digital, como ocorre no Estado do Maranhão, onde apenas 2,1\% da população possui computador. * Esse impacto dos investimentos em infra-estrutura tecnológica para acesso à informação é refletido no meio científico, em que a maior parte da produção concentra-se nas universidades da região Sudeste brasileira (MEIS e col. 2003).

Na questão dos investimentos dos países em tecnologia, CASTELLS (1999) alerta sobre o importante papel de cada sociedade para a forma pela qual se utiliza ou não a tecnologia. Para o autor, a tecnologia não determina a sociedade e nem a sociedade determina a tecnologia; porém, o modo como as sociedades dominam sua tecnologia molda o seu próprio modo de vida; as mudanças tecnológicas se tornam o ícone da capacidade de transformação das sociedades contemporâneas. Assim, afirma: “(...) a tecnologia (ou sua falta) incorpora a capacidade de transformação das sociedades, bem como os usos que as sociedades, em um processo conflituoso,

\footnotetext{
*Comitê Gestor da Internet no Brasil - composto por representantes dos vários Ministérios do Governo Brasileiro, do setor empresarial, da comunidade científica e tecnológica e do terceiro setor para coordenar e integrar as iniciativas de serviços da Internet no Brasil. Divulga números atualizados da rede no Brasil. [Informação obtida em http://www.cg.org.br, 16 fev 2004]
} 
decidem dar ao seu potencial tecnológico" (v.1, p.26). A grande ameaça da internet, como mídia aberta e descentralizada, é o aumento de grupos que criam suas próprias revistas, emissoras de rádios ou de televisão, sem pedir licença ao Estado; cada um pode dizer nela o que quiser, oferecer serviços, entre outros. A distância não é mais geográfica, e sim econômica, cultural e ideológica (MORAN 1997).

Dessa forma, os investimentos que os países fazem (ou farão) em tecnologia da informação estão intrinsecamente relacionados às suas pressões econômicas. Um computador ligado em rede custa muito mais que um livro, mas pode fornecer muito mais informações. O custo para manter redes eletrônicas e equipamentos para comunidades acadêmicas pode ser inviável para um país em desenvolvimento, fazendo com que seus pesquisadores sintam-se à margem da comunidade científica mundial (MEADOWS 1999).

Portanto, os países desenvolvidos, dependentes da informação para obter vantagem competitiva, devem promover a aceleração do desenvolvimento tecnológico, em permanente e veloz transformação. Os países em desenvolvimento que não alcançarem essa agilidade ficarão marginalizados. MEADOWS (1999) alerta para a preocupação de vários especialistas na era da informação: a divisão entre os "ricos em informação" e os "pobres em informação", ou seja, entre pesquisadores de instituições que têm bom acesso a internet e aqueles que não o têm (p.159).

Mesmo tendo sido anunciado que os gastos com serviços mundiais de armazenamento digital subiriam de 682 milhões de dólares em 2001 para 10,7 bilhões em 2005 (TERRA e GORDON 2002), sabe-se que muitos países não conseguiriam dotar seus pesquisadores de equipamentos adequados, tornando-os excluídos quanto 
ao acesso à informação de um modo que jamais seria possível com os meios impressos (MEADOWS 1999).

Mesmo inserido nesse contexto econômico e tecnológico, o pesquisador brasileiro nunca produziu tanto nem com tanta qualidade, mas sofre com as pressões para publicar em revistas de renome, fruto da cultura científica de países desenvolvidos, e com a queda do apoio governamental, praticamente a única fonte de financiamento para suas pesquisas (MEIS e col. 2003).

\subsection{Definindo a internet}

A tecnologia da informação tem seu maior produto na internet, considerada um poderoso instrumento de comunicação que diminui distâncias, interliga pesquisadores e permite que a informação produzida seja facilmente localizada em acervos das mais diversas áreas do conhecimento.

A internet é uma rede de computadores interligados por meio do padrão aberto (não depende de nenhum fabricante) TCP/IP (Transmission Control Protocol/ Internet Protocol). Compõe-se de diferentes recursos que possibilitam a comunicação e o envio de dados entre os computadores de uma rede. Esses recursos, os protocolos de aplicação, são conhecidos como ferramentas e serviços (FONTES 2001).

A internet foi instituída na década de 60 , como a primeira tentativa de se compartilhar recursos informacionais, inicialmente pelo Reino Unido (em 1968) e França, em 1969. Foi fundamentada e organizada pelo Departamento de Defesa dos Estados Unidos (US Defense Department's Advanced Research Projects Agency - 
ARPA), consolidando-se sob o nome de ARPANET. No início dos anos 80 a ARPANET foi testada pela primeira vez entre duas universidades americanas, inaugurando a BITNET (Because It's Time Network) e a era do correio eletrônico (FERREIRA 1995). Até o fim dos anos 80 expandiu-se para outros países, ainda para uso exclusivo da comunidade acadêmica. Na década de 90 foi se expandindo para fora do âmbito universitário, distribuindo-se pelo mundo todo em conjunto com a disseminação da microinformática (CASTELLANI 1998).

No Brasil, a implementação da internet teve inicio a partir de 1987. Em 1988, com apoio da FAPESP, as universidades paulistas passaram a comunicarem-se por meio da ANSP (Academic Network at São Paulo), para fins de pesquisa e, a partir de 1995, a internet foi aberta para exploração comercial (FONTES 2001).

Um dos recursos mais importantes e mais utilizados da internet é a troca de mensagens via correio eletrônico (e-mail), que pode ocorrer entre um e outro usuário e entre grupos de usuários, por meio da participação em listas ou grupos de discussões. Cada uma dessas alternativas possui programas próprios. Estima-se que, nos Estados Unidos, as pessoas enviem cerca de 1,5 bilhão de mensagens de e-mail por dia, gastando aproximadamente 108 minutos diários apenas gerenciando esse tipo de recurso da internet (TERRA e GORDON 2002). Esses números, comparados aos de correio postal, significam que, para cada correspondência impressa, são enviados cerca de 30 e-mails. *

\footnotetext{
*Wurman RS. Ansiedade de informação citada em reportagem na Folha de São Paulo, 3 jul. 2003.

Caderno Equilíbrio, p.8.
} 
As listas ou grupos de discussão funcionam como extensão do correio eletrônico, que podem ser utilizados para comunicação entre membros de um projeto ou de pessoas interessadas em temas específicos, podendo ser abertos ou restritos à participação de novos indivíduos (MACEDO e MODESTO 1999). Funcionam como murais eletrônicos ou fóruns de discussão, nos quais as pessoas disponibilizam para outras pessoas simultaneamente comunicações sobre um assunto de interesse comum (SILVA 1997). O gerenciamento desse tipo de recurso da internet é feito por programas específicos, que controlam o fluxo de distribuição de mensagens, admitindo ou cancelando assinaturas. Atuam como rápidos e eficientes canais de comunicação entre especialistas, permitindo colaboração entre pares, alcançando grande número de pessoas de forma praticamente instantânea (FONTES 2001).

SELWYN (2000), acompanhando durante dois anos um grupo de discussão composto por professores de escolas britânicas, verificou que esse fórum foi utilizado principalmente para troca de informações e que seu ponto negativo foi a falta de participação de todos. MOLYNEUX e WILLIAMS (1999) estimaram, em 1996, a existência de cerca de 20 mil grupos de discussão, sendo que, em 1999, seriam 25 mil, apontando para um crescente uso dessa ferramenta da internet.

Ainda referindo-se à comunicação entre os usuários da internet, está o recurso do bate-papo, mais conhecido como chat. Ele permite a criação de uma tela na qual um ou mais participantes podem digitar seus textos, estabelecendo um diálogo em tempo real. É o recurso mais informal da internet, disponível em "salas", como nas páginas da web, ou em programas específicos. No Brasil, uma das experiências com bate-papo no âmbito acadêmico é o "Ponto de Encontro", criado pelo Prossiga (CNPq 
- Comunicação e Informação para a Pesquisa) (www.prossiga.br), que reúne virtualmente pesquisadores para troca de idéias sobre projetos em andamento (FONTES 2001). O Programa Prossiga atualmente encontra-se em fase de revisão.

Outra possibilidade de uso da internet é a teleconferência, recurso utilizado no meio acadêmico-científico não só para reuniões, que podem ser programadas e realizadas à distância, como principalmente para o ensino, em complementação a aulas presenciais e palestras. No Brasil, esse recurso vem sendo paulatinamente inserido no meio acadêmico, principalmente por demandar fortes investimentos das instituições em tecnologia de redes eletrônicas e equipamentos, telecomunicações e recursos humanos.

Atualmente, a interface de hipermídia da internet mais conhecida é a web ou World Wide Web (Teia Global) - ou www - que, manipulada por programas especiais chamados browsers, caracteriza-se por ser uma coleção de documentos em hipertextos ligados entre si, criando um mundo de informações digitais que envolvem textos, imagens e sons. Os usuários, por meio de computadores conectados a servidores (hosts), navegam por sítios (sites) informacionais, interligados por vínculos (links) das páginas iniciais* (homepages) de outros sítios, ${ }^{* *}$ realizando a parte cliente do sistema cliente-servidor que compõe a internet. Dessa forma, a web permite o

\footnotetext{
“Páginas iniciais na web - página principal, de abertura de um site, e através da qual o programa navegador, uma vez indicado seu endereço (URL), tem acesso ao referido site (Dicionário Houaiss da Língua Portuguesa,2001).

" Site ou sítio na internet - local na internet identificado por um nome de domínio, constituido por uma ou mais páginas de hipertexto, que podem conter textos, gráficos e informações em multimidia. (Dicionário Houaiss da Língua Portuguesa,2001)
} 
deslocamento de um documento de um computador ao outro, por programas (softwares) denominados navegadores (NAHUZ 1999).

Um recurso embutido na web e que tem sido bastante utilizado pela comunidade acadêmica é a transferência de arquivos, conhecida como FTP (File Transference Protocol). Esse comando permite conexão de um computador a um servidor remoto no qual podem ser transferidos, recíproca e simultaneamente, textos, programas, sons, imagens e animações (MACEDO e MODESTO 1999, FONTES 2001). Por estar na web, o FTP tem seu uso facilitado, propiciando à comunidade acadêmica aplicação em várias de suas atividades, como as ligadas à administração acadêmica e à atualização de seus currículos, entre outras.

Cabe comentar, especificamente sobre a web, aspectos sobre seu crescimento e conseqüente disponibilidade de informações. De acordo com pesquisa realizada em junho de 1999 sobre o crescimento da internet no mundo, foi detectado que a rede contava com cerca de 2 bilhões de páginas na web, sendo criadas a cada dia uma média de 7 milhões de novas páginas (GARATTONI 2001). Outros dados, em meados de 2000 (TERRA e GORDON 2002), apontam para cerca de 550 bilhões de documentos na web e outros, ainda, para 800 milhões (FALCÃO 2000). De toda essa produção de páginas e conseqüente quantidade de informações, estudos confirmam que $83 \%$ desse conteúdo é de cunho comercial (LAWRENCE e GILES 1999).

O fato é que a internet tem propiciado grande facilidade na comunicação e também gerado problemas com o excesso de informações. Torna-se cada vez mais elevado o número de dados, muitas vezes irrelevantes, encontrados nas páginas da web. A esse respeito, REPMAN e CARLSON (1999 p.1), comparando a situação do 
usuário com a de um náufrago, comentam: “...água, água por todo lado, porém nenhuma gota para beber...".

Todo esse volume de informação na web tem sido considerado um dos principais problemas da internet, pois não existe um diretório universal de endereços que possa executar múltiplas e abrangentes buscas na web, fazendo com que o usuário não precise consultar mais de um sistema de busca, sem perder milhares de outras informações importantes (ARAUJO 1999/2000, CIANCONI 2001, LAWRENCE e GILES 1998, POWELL e FOX, 1998). Corroborando essa afirmação, o motor de busca HotBot recupera apenas 34\% das páginas indexáveis (MARCONDES e SAYÃO 2001); o AltaVista, apenas 28\%; o Excite, 14\%; o Infoseek, 10\%; sem contar que alguns sites podem negar a permissão de visita de um motor de busca. Atualmente, o motor de busca mais utilizado tem sido o Google, que indexa cerca de 4 trilhões de páginas, no maior banco de dados existente.*

Além dos motores de busca, algumas iniciativas foram criadas para tentar minimizar o problema de busca de informações na web, como as bibliotecas virtuais que coletam e classificam informações de sites, num tipo de ferramenta que recupera informações validadas da web. No Brasil, são conhecidas na área da saúde a Biblioteca Virtual em Sáude da BIREME, no seu componente LIS (Localizador de Informações em Saúde ${ }^{* \star}$ ), e Sites em Saúde Pública ${ }^{\star \star \star}$, além das bibliotecas virtuais

\footnotetext{
*Google Inc [http://www.google.com], consultado em abril 2004

** O LIS pode ser consultado na Biblioteca Virtual em Saúde, no endereço < http://www.bireme.br>

${ }^{* *}$ Sites em Saúde Pública pode ser consultado na Biblioteca Virtual em Saúde Pública, no endereço:

<http://www.saudepublica.bvs.br>
} 
temáticas do Prossiga/CNPq nas áreas de saúde reprodutiva ${ }^{* \star *}$ e de saúde mental $^{\star \star \star \star *}$.

Outro problema na web, apontado por diversos autores, é a quantidade de links irrelevantes (CIANCONI 2001, VOORBI, 1999) e inativos, provocados pela desatualização dos sites (CIANCONI 2001), fazendo com que não se possa garantir a permanência do texto na web (MARCHIORI 2002). KOEHLER (1999) estimou que $17,7 \%$ dos websites e $31,8 \%$ das páginas na web desaparecem em um ano, e 0,5\% em uma semana; outros 5\% desaparecem e voltam a aparecer em uma semana; $31 \%$ mudam de endereço, e $97 \%$ sofrem algum tipo de alteração no período de um ano. Devido a esses problemas defrontados diariamente, a comunidade acadêmica ainda não deposita total confiança nos meios eletrônicos para busca e disponibilização de informações científicas.

\subsubsection{Números da internet no Brasil}

As estatísticas sobre a internet no Brasil, fornecidas pelo Comitê Gestor da Internet no Brasil ${ }^{\star}$ (2004), mostram o país ocupando a $29^{a}$ posição entre as nações mais informatizadas do mundo, mais o primeiro lugar na América do Sul e o oitavo lugar no mundo quanto ao uso da internet. Em números mais significativos, com uma população de 167,7 milhões de habitantes, 12,46\% têm computador, e 8,31\% utilizam a internet (Fundação IBGE 2001).

\footnotetext{
${ }^{\star \star \star \star}$ Biblioteca Virtual em Saúde Reprodutiva: <http://www.prossiga.br/fsp_usp/saudereprodutiva>

${ }^{\star \star \star \star \star}$ Biblioteca Virtual em Saúde Mental: <http://www.prossiga.br/ee_usp/saudemental>

*Comitê Gestor da Internet no Brasil [Informação obtida em http://www.cg.org.br, 16 fev 2004]
} 
Números sobre a internet surgem quase diariamente, porém são, muitas vezes, desconexos. Por exemplo, o DataFolha, ${ }^{\star *}$ em 2001, anunciou que o Brasil abrigava cerca de 23 milhões de internautas (19\%), cifra que em junho de 2002, de acordo com o Comitê para a Democratização da Informática (CDI) presente no Brasil*, girava em torno de 20 milhões (12\% da população). Em 2004, o mesmo CDI registrava cerca de 31 milhões de usuários (18\% da população), com previsão de que, a cada quatro meses, mais de um milhão de pessoas passem a ter acesso a computadores com internet.

Outra estimativa sobre os internautas brasileiros foi apresentada em artigo sobre a Sociedade da Informação no Brasil (MIRANDA e col. 2000), apontando, em 2000, mais de 6 milhões de usuários da internet e prevendo que, nos próximos cinco anos, esse número se elevaria para os 30 milhões. Segundo CASTILHO FILHO (1998), a grande maioria dos brasileiros acessa a internet de sua própria casa (79\%), do trabalho (41\%) ou da escola (11\%).

\footnotetext{
* Informação obtida em pesquisa realizada pelo DataFolha publicada na Revista da Folha, em número especial de 27 de setembro de 2001, p.6, com o título "iBrands fotografa o mundo virtual".

*CDI - Comitê para a Democratização da Informática: organização não-governamental sem fins lucrativos que colabora na promoção da inclusão social de cegos, doentes mentais, presos, minorias étnicas e comunidades carentes, utilizando a tecnologia da informação como um instrumento para a construção e o exercício da cidadania [Informação obtida em www.cdi.org.br, em 16 fev 2004], presente em 23 cidades brasileiras e mais quatro outros países - Japão, México, Colômbia e Uruguai, tendo capacitado cerca de 48 mil brasileiros (FERREIRA 2003).
} 
Outro aspecto interessante ligado à internet é a distribuição dos chamados domínios da internet ${ }^{\star \star}$. Segundo o Comitê Gestor da Internet no Brasil, em 2004 foram registrados 612.645 domínios, sendo 91,2\% para fins comerciais (com.br). Os demais foram para órgãos governamentais (gov.br), com 0,13\%, e para educação (edu.br), usados pelas universidades, com apenas $0,35 \%{ }^{*}$.

Quanto à distribuição geográfica dos usuários da internet no Brasil, a maior concentração está na Região Sudeste (57\%). Estudos da Fundação Getúlio Vargas (2003) mostram que os Estados onde ocorre a maior taxa de inclusão digital são Distrito Federal (23,9\%), São Paulo (18,0\%) e Rio de Janeiro (18,0\%) (FGV 2003).

Ainda assim, esses números são considerados baixos. Apesar de investimentos do Governo Federal, como o Programa Sociedade da Informação, que almeja efetivar a construção de uma sociedade baseada no uso intensivo de informação, destituída de analfabetismo e que permita acesso do cidadão comum às novas tecnologias de informação (FERREIRA 2003), o Brasil apresenta Estados com índices muito baixos de inclusão digital, como o Maranhão, com apenas 2,1\% da população com computador. Seguem os Estados de Tocantins e Piauí, ambos com 2,8\% de incluídos digitais (FGV 2003).

\footnotetext{
** Domínio na internet - expressão que serve para localizar e identificar conjuntos de computadores na internet, concebido com o objetivo de facilitar a memorização dos endereços de computadores na internet. [Informação obtida em http://www.cg.org.br, 16 fev 2004]

* Informação obtida no site do Comitê Gestor da Internet no Brasil em http://www.cg.or.br, em fevereiro de 2004.
} 


\subsection{A comunicação do conhecimento científico}

A pesquisa se desenvolve com base em conhecimento acumulado, dado a público por meio de publicações e, também, de contatos informais entre os pesquisadores. Essa comunicação em ciência é fortemente influenciada pela internet. 
As publicações dos achados em ciência são consideradas os canais formais de comunicação científica ou de literatura e são representadas, principalmente, por artigos de periódicos e livros, que têm uma existência mais duradoura. Já a comunicação informal entre os pesquisadores é caracterizada pela comunicação oral e destituída de formalização, como cartas, preprints e comunicações em congressos, entre outras (GARVEY 1979, MEADOWS 1999). Alguns autores incluem, entre esses dois canais básicos, a existência de uma forma de comunicação científica semiformal, na qual os resultados de pesquisa são apresentados numa forma híbrida: oral, com as discussões que provocam, e escrita, com características formais, como os preprints, prepapers, cartas aos editores e as comunicações em congressos, que podem vir a ser editados ou não (CHRISTÓVÃO 1979).

Com a internet, os conceitos de formal e informal vêm se modificando e, no ambiente eletrônico, estão representados principalmente pela disponibilização de textos na web e pela troca de informações via correio eletrônico, chats, listas e grupos de discussão. Nesse meio eletrônico, os pesquisadores podem submeter a seus pares preprints, papers, letters, entre outros, antes de sua veiculação, ou mesmo disponibilizá-los em periódicos eletrônicos como publicação formal.

$\mathrm{Na}$ comunicação informal entre os pesquisadores, algumas alterações provocadas pela internet já podem ser notadas, como a substituição de cartas e contatos pessoais por mensagens eletrônicas, e conversas por chats, grupos, listas de discussão e reuniões científicas por meio de teleconferências. Alguns autores enfatizam como alteração mais significativa da internet a substituição do chamado colégio invisível tradicional pelo correio eletrônico (HURD 2000) e pelos grupos e listas 
de discussão (MEADOWS 1999), desempenhando papel importante na troca de informação entre os pesquisadores, transformando-se em colégio invisível eletrônico (HURD 2000).

O correio eletrônico tornou-se um importante elo entre os pesquisadores, pois permite acesso fácil aos profissionais e especialistas, troca de experiências de modo rápido, ágil, informal, democrático e desvinculado de padrões hierárquicos (FERREIRA 1995). Pesquisadores jovens podem ter oportunidade de atuar com pesquisadores experientes, tornando a hierarquia da pesquisa menos acentuada graças a essa comunicação informal (MEADOWS 1999).

Na comunicação científica, o correio eletrônico é apontado em vários estudos (ANDRADE e col. 2003, CASTELLANI 1998, COBB e BAIRD 1999, FERREIRA 1995, LAZINGER e col. 1997, STUDT 1998 e 2000, SILVA 1997, entre outros) como o serviço mais popular da internet, por permitir de maneira simples a troca de mensagens favorecendo o compartilhamento de informações entre os pesquisadores (MACEDO e MODESTO 1999).

A comunicação informal, como acontece nas demais áreas do conhecimento, tem obtido espaço cada vez mais marcante entre os pesquisadores da área de saúde pública, conforme já detectado por NORONHA em 1996, o que se acentuou principalmente desde a década de 90 com o advento da internet nas atividades acadêmicas.

Nas atividades acadêmico-científicas, o correio eletrônico influencia nos padrões de trabalho acadêmico principalmente na elaboração de pesquisas e 
publicações conjuntas (BUDD e CONNAWAY 1997), propiciada pela inexistência de barreiras geográficas e pela participação interdisciplinar, conforme afirmações em LUBANSKI e MATTHEW, 1998 (p.9): “(..) coordeno pesquisa com co-autores via correio eletrônico (...) tive publicação conjunta com colegas que jamais vi.”

$\mathrm{Na}$ publicação dos resultados da pesquisa científica, importante etapa do processo da comunicação científica, o artigo de periódico é o mais representativo canal formal de publicação, sendo considerado um dos veículos de mais credibilidade no meio acadêmico-científico. Além do artigo de periódico, também são considerados canais importantes para a divulgação da ciência documentos como livros, capítulos de livros, teses, dissertações e trabalhos publicados em anais de congressos, entre outros.

Com as novas tecnologias da informação e a internet, os periódicos científicos e os demais tipos de publicações têm sido disponibilizados também por meio eletrônico, principalmente na forma on-line, mantendo ou não seu correspondente impresso. Os pesquisadores convivem simultaneamente com ambos os formatos; enquanto o impresso os beneficia com sua forma linear de leitura, que Ihes facilita a assimilação de idéias, o outro pode Ihes possibilitar interatividade e consulta mútua a inúmeros outros documentos, imagens e sons (MARCHIORI 2002). 


\subsubsection{Os intermediários na comunicação científica e a tecnologia da} informação - a editoria científica

A transição do impresso para o eletrônico na comunicação científica tem sido muito facilitada graças ao importante papel dos editores e profissionais da informação que têm a difícil tarefa de organizar a transferência de informações (MEADOWS 1999). Os profissionais da informação são os que tratam e armazenam o material oriundo das editoras, de modo que possam ser acessíveis aos pesquisadores. Os editores científicos incumbem-se de receber os textos, selecioná-los, prepará-los para publicação e assim divulgar os resultados da ciência.

Com a inserção das tecnologias da informação na editoração dos textos científicos, autores, editores e profissionais da informação passaram a conviver com softwares e as mais diversas linguagens que facilitam a elaboração de textos e que também podem receber imagens e sons, entre outros recursos multimídia (MARCHIORI 2002). Os controles de manuscritos e relatorias nas editoras científicas foram mais facilitados pelos e.prints (softwares ligados a bancos de dados), que possibilitam entrada de dados, recuperação, manutenção de correspondência, saída de relatórios, controle de fluxo, gerenciamento de manuscritos e acompanhamento do processo de avaliação, entre outros (HURD 2000, MARCHIORI 2002).

Recentemente foi divulgado que cientistas norte-americanos anunciaram uma editora científica virtual sem fins lucrativos, a Public Library of Science (www.publiclibraryofscience.org), que pretende lançar títulos eletrônicos gratuitamente via internet para competir com grandes revistas do setor, como a Science e a Nature 
(FAPESP 2003). No Brasil, iniciativa do Projeto SciELO tem objetivo similar, ou seja, beneficiar a inserção da literatura científica brasileira no cenário nacional e internacional.

Da mesma forma, inciativas como as do IBICT (Instituto Brasileiro de Informação em Ciência e Tecnologia) (www.ibict.gov.br), com o projeto Biblioteca Digital Brasileira, são tentativas de possibilitar à comunidade brasileira da área de ciência e tecnologia a publicação de seus trabalhos de forma rotineira, diretamente na rede (MARCONDES e SAYÃO 2001). A disponibilização de documentos inéditos, na íntegra, de acesso universal e gratuito, já é uma tendência na concepção das bibliotecas virtuais, sendo uma delas dada a público em 2001: a Editora Eletrônica* de textos em saúde pública, projeto da Faculdade de Saúde Pública da USP em parceria com a BIREME.

Seguindo essas tendências, a novidade no meio científico é a disponibilização pelos autores de textos não revisados em websites, nos quais podem ser avaliados por seus pares, constituindo-se em um espaço virtual destinado à divulgação científica (MARCHIORI 2002). São os chamados open archives ${ }^{* \star}$ ou arquivos abertos. Entre outros, podem ser citados o da Elsevier Science - The Mathematics Preprint Server (www.mathpreprints.com); o Clinical Medical \& Health Research (clinmed.netprints.org), da British Medical Association Publishing Group e da Stanford

\footnotetext{
*Editora Eletrônica da Faculdade de Saúde Pública da USP, integrante da Biblioteca Virtual em Saúde Pública, desenvolvida em parceria com a BIREME, pode ser consultada no endereço http://www.bvs.sp.fsp.usp.br/tecom/index.html

** Open Archives - podem ser definidos como espaços virtuais destinados à divulgação de textos científicos, arbitrados ou não pelos pares (SENA 2000)
} 
University Library's High Wire; e o PubMed Central (http://www.pubmedcentral.nih.gov), serviço do National Center for Biotechnology Information, divisão da National Library of Medicine.

A comunicação eletrônica veio para ficar e tende a eliminar os intermediários. No processo da comunicação científica, a internet possibilita ao receptor da informação a participação direta no processo, ou seja, interagir com o autor sem intermediários. Com tais facilidades, não só a divulgação do conhecimento tende a tornar-se mais rápida, como o seu acesso e julgamento podem ser facilitados (TARGINO 1999/2000). O receptor passa a ser o juiz da relevância da informação acessada em tempo real, retroalimentando o ciclo da informação científica (BARRETO 1998).

Nesse cenário, não há dúvida de que a internet facilita a divulgação e promove mais visibilidade à ciência em âmbito mundial.

Torna-se difícil prever o futuro das publicações e do processo da comunicação científica na era das redes eletrônicas. O cientista deve lançar mão de todos os meios possíveis de divulgação da ciência, porque a comunicação eficiente e eficaz é parte fundamental do processo de pesquisa científica (MEADOWS 1999). Os resultados de pesquisa devem ser divulgados nos canais formais, impressos ou eletrônicos, e também nos diversos fóruns de comunicação científica informais, como congressos, palestras e reuniões científicas, na forma presencial ou via internet. Alguns autores orientam esse tipo de conduta afirmando que "(...) é possível reportar oralmente uma mesma pesquisa mais de uma vez, mas ela também pode aparecer em mais de um tipo de publicação" (MEADOWS 1999 p.164) e "(...) mediante uma sólida e 
imprescindível exposição de motivos aos editores para autorização de praxe" (TARGINO 1999/2000).

\subsubsection{Os intermediários na comunicação científica e a tecnologia da} informação - bibliotecas e sistemas de informação

Assim como os editores científicos, as bibliotecas e os sistemas de informação* passaram a ter papel fundamental na organização da informação no formato eletrônico, e deles depende a transferência da informação para o acesso público, influindo fortemente no processo da comunicação científica, especialmente no tempo entre a produção do conhecimento e sua assimilação pelo público.

As bibliotecas passaram a utilizar a tecnologia de redes eletrônicas fazendo com que os recursos que tradicionalmente usam pudessem ser adaptados para as novas formas de tratamento e busca da informação. Os fichários passaram a ser substituidos por catálogos de acesso público (OPAC's - On-line Public Access Catalogs). Os sistemas de informação fortaleceram o trabalho cooperativo via internet, possibilitando a catalogação e a indexação compartilhadas na web, pelas quais inúmeras bibliotecas, a partir de um único registro, podem agregar-lhe valor, de acordo com a necessidade de seu usuário.

\footnotetext{
*Sistemas de informação referem-se aos chamados sistemas de informação científica que são constituídos por bases de dados bibliográficas, resultantes do controle e registro da literatura científica produzida em nível institucional, nacional, regional ou temático. Com a internet podem expandir-se para bases de textos completos, que permitem acesso direto aos documentos recuperados (CASTRO 2003 p.59)
} 
De forma simultânea, os bibliotecários podem consultar listagens de assuntos como o MeSH (Medical Subject Headings) ou o DeCS (Descritores em Ciências da Saúde) e acessar inúmeras bases de dados de acervos. É o caso do OCLC (Ohio Colleges Library Center), que agrega acervos de 21 mil bibliotecas, em 62 países, compartilhando um banco com cerca de 30 milhões de registros. *

No Brasil, a Universidade de São Paulo foi pioneira, na década de 90, na disponibilização de catálogos on-line, como o Banco de Dados Bibliográfico Dedalus. Atualmente esse banco é integrado aos da UNESP e UNICAMP, formando o Portal CRUESP, com acesso universal aos acervos de 82 bibliotecas das três universidades paulistas. Esse catálogo on-line compartilha registros de 2,5 milhões de livros, 230 mil teses e 86 mil títulos de periódicos, além de 700 mil materiais especiais. **

Assim, os acadêmicos podem contar com bibliotecas que disponibilizam serviços remotos, via websites ou correio eletrônico. Essas tendências apontam para o surgimento, principalmente em países mais desenvolvidos, dos serviços de referência virtual (BUSHALLOW-WILBUR e col. 1996) realizados em tempo real. No Brasil, algumas experiências em bibliotecas acadêmicas já são relatadas. Na área da saúde, a Biblioteca da Faculdade de Saúde Pública da USP instituiu, em 1998, um serviço de referência virtual (CUENCA e col. 2003), no qual a comunidade acadêmica pode obter respostas a questões bibliográficas através dos serviços on-line e do correio eletrônico. Mais recentemente, com a proliferação das bibliotecas virtuais na área da saúde, esse

\footnotetext{
*Folder OLCL 2002

** Informação obtida no Folder CRUESP 2003 e Portal CRUESP <http://www.cruesp.bc.unicamp.br>
} 
tipo de serviço, que independe da ida do usuário a uma biblioteca real, é disponibilizado a toda população.

Os sistemas de informação e várias bibliotecas passaram também a atuar no desenho e na construção de interfaces gráficas para websites, intranets, portais e bases de dados, provocando mudanças no comportamento da comunidade científica quanto ao uso da tecnologia para o acesso à informação. Isto possibilita integração entre profissionais bibliotecários, analistas de sistemas, programadores e webdesigners, que passaram a compor as equipes que criam, organizam, administram e mantêm os serviços e produtos dos portais e websites. Em vários casos, essas equipes contam com o apoio de pesquisadores como forma de garantia de adequação dos serviços prestados e de qualidade dos conteúdos.

Outro aspecto importante de atuação das bibliotecas e dos sistemas de informação tem sido a capacitação da comunidade acadêmica para o uso da internet. Vários pesquisadores começaram a usar computadores pela necessidade de busca da informação e pela participação em treinamentos para uso das bases de dados nas bibliotecas (CUENCA 1999), e, a partir de uma experiência positiva com uso dessas tecnologias, a tendência de uso futuro sem resistência à máquina tende a se instalar (COFFIN e MacINTYRE 1999).

Alguns estudos relatam a experiência de programas educativos em bibliotecas acadêmicas, destinados a tornar seus usuários auto-suficientes na busca da informação através de bases de dados. Este é um dos desafios das bibliotecas na era das redes eletrônicas: capacitar seu usuário para qualquer tecnologia disponibilizada. Em artigos publicados sobre uso de bases de dados pela comunidade acadêmica 
brasileira na área da saúde, CUENCA e col. (1999) chamam a atenção para a importância de oferecer programas de capacitação e treinamentos, em níveis diferenciados, de acordo com a necessidade de informação de cada usuário.

Pode-se afirmar que a evolução das bibliotecas tradicionais para o mundo virtual é um fato atrelado à própria evolução da internet (ARAUJO 1999/2000). Nesse processo, as bibliotecas virtuais continuarão fundamentais no processo da comunicação científica, já que a informação que é produzida em formato impresso se tornará cada vez mais disponível em meio digital (DINIZ 1999). Alguns autores já consideram a possibilidade de que as bibliotecas virtuais de periódicos científicos sejam importantes para o crescimento do impacto internacional das publicações (ALONSO e FERNANDEZ-JURIDIC 2002).

\subsection{A literatura científica sobre a internet}

A literatura publicada sobre a internet nas comunidades acadêmico-científicas passa a se destacar com mais freqüência na década de 90, embora desde o final da década de 70 e início dos anos 80 já se observassem, nos países desenvolvidos, estudos sobre as novas tecnologias da informação, inclusive das redes eletrônicas. Em um dos primeiros estudos realizados, SCHAUDER (1994) destaca que apenas uma pequena parcela da comunidade científica do Reino Unido, Estados Unidos e Austrália era usuária de redes eletrônicas, apontando para a pouca influência dessas redes na comunicação científica. A partir de então, os estudos tornaram-se mais freqüentes, investigando a influência da internet em comunidades científicas, inclusive na área de saúde pública, e apontando para uso intensivo de seus recursos, principalmente o 
correio eletrônico e a web (APPLEBEE e col. 1997, APPLEBEE e col. 2000, BRUCE 1995, BRUCE 1998, BRUCE 1999, BUDD e CONNAWAY 1997, HOLLANDER e MARTIN 1999, JORDAAN e JONES 1999, JACOBS 1998, KORNER e col. 2003, LAZINGER e col. 1997, LUBANSKI e MATTHEW 1998; VOORBIJ 1999, WALSH e col. 2000, entre outros). Outros trabalhos, como o artigo de revisão sobre a internet por MOLYNEUX e WILLIAMS (1999), apontam vários aspectos pouco abordados na literatura, como o uso de grupos e listas de discussão.

No Brasil, algumas pesquisas estão sendo desenvolvidas sobre o tema e tidas como importantes para o mapeamento da evolução do uso da internet nas comunidades acadêmicas de diferentes áreas.

A internet tem sido, sobretudo, objeto de estudo de dissertações e teses produzidas no Brasil, cujos resultados, muitas vezes, nem chegam a ser divulgados em uma publicação formal (STUMPF 1997). Um dos primeiros estudos acadêmicos foi o de FIGUEIRA NETTO em 1994, no qual pesquisadores brasileiros usuários da então rede acadêmica BITNET, no país e no exterior, afirmaram ser a comunicação informal o maior benefício dessas redes. Na mesma linha, FERREIRA, em 1995, evidenciou as necessidades de informação de uma comunidade universitária do campo da física com vistas à compreensão do papel das redes eletrônicas em suas atividades acadêmicas e concluiu que as redes trouxeram nova dimensão à comunicação científica, facilitando a comunicação entre os pesquisadores.

Desde 1997, os estudos acadêmicos sobre a internet tornam-se mais presentes na literatura, como o de SILVA (1997), que, ao analisar os reflexos da implantação da tecnologia da informação na busca e na troca de informações entre os pesquisadores 
da área de engenharia, encontrou maior uso do correio eletrônico pela maioria da comunidade estudada, e CASTILHO FILHO (1998), que avaliou casos de empresas brasileiras, apontando para maior uso da web. Em 1997, CASTELLANI analisou o uso da internet em comunidades acadêmicas de áreas distintas: ciências exatas e humanas, advogando a favor da tecnologia como instrumento de ajuda para as atividades desenvolvidas no meio acadêmico. Além desses estudos, pode ser citada a tese de BOTELHO (1997) sobre o impacto da internet na comunicação informal de docentes de pós-graduação, pela qual concluiu que, embora menos da metade da comunidade da área de administração utilizasse a internet, seus membros consideravam o correio eletrônico um forte substituto da comunicação científica formal.

Além das teses e dissertações, destacam-se alguns artigos publicados no Brasil sobre a internet. Na área de saúde pública, ITURRI, em 1998, discorreu sobre os benefícios e as desconfianças do pesquisador da área de saúde pública quanto ao uso da internet, apontando, entre outras considerações, a resistência ao aprendizado das novas tecnologias, a dificuldade em compartilhar recursos e informações na própria instituição ou fora dela e a percepção de que a tecnologia reduz pessoal e tende a desumanizar a sociedade. Já ANDRADE e col., em 2003, em artigo sobre o uso das novas tecnologias de informação pelos docentes de instituição acadêmica da área, verificaram que a grande maioria utiliza os recursos de informática disponíveis, sendo que cerca de $50 \%$ deles no ambiente de trabalho, apontando o maior uso para o correio eletrônico e para a consulta a bases de dados via web. Em uma das considerações finais desse estudo, os autores destacaram que a comunidade acadêmica na área de saúde pública necessita da ajuda de bibliotecários para o uso 
das novas tecnologias da informação, considerando o treinamento a forma mais eficaz para auxiliar o docente no uso das tecnologias.

\subsection{Sobre a proposta do presente estudo}

Considera-se que um estudo realizado sobre as influências da internet na comunidade de docentes dos programas de pós-graduação stricto sensu, da área de saúde pública, possa contribuir não só para os próprios programas como também para as respectivas instituições, servindo como subsídio no planejamento de ações que insiram cada vez mais a comunidade científica e acadêmica brasileira no ambiente tecnológico e que venham a beneficiar o desenvolvimento e aprimoramento da pesquisa nessa área.

A comunidade de docentes da área de saúde pública, assim como nas demais áreas do conhecimento, representa um elo significativo no ciclo da comunicação científica porque produz conhecimento e forma pesquisadores. Essa comunidade gera e transmite o conhecimento; portanto, pode contribuir com opiniões importantes sobre a inserção das novas tecnologias em suas atividades de ensino e pesquisa, que podem subsidiar investimentos na área e novos estudos sobre o assunto.

As novas tecnologias da informação inseridas em comunidades acadêmicas carecem de mais estudos, identificando-se as peculiaridades de cada área do conhecimento em relação aos padrões de comunicação científica existentes. Assim, pode-se verificar se as comunidades acadêmicas estão prontas para usufruir desse 
novo modelo de comunicação virtual e quais padrões devem ser adotados para a área em questão (HARRISON e STEPHEN 1995). O docente, como parte determinante de todos os sistemas de informações, merece especial atenção quanto a suas características pessoais e necessidades e pontos de vista em relação ao uso da internet (MEADOWS 1999).

O propósito do presente estudo é principalmente entender o que ocorre com o uso da internet no ambiente acadêmico da área de saúde pública. O conhecimento de atitudes e práticas relativas ao uso da tecnologia da informação pelo docente pode dar a conhecer como essa comunidade absorve a tecnologia para o desenvolvimento de atividades acadêmico-científicas. Estudos dessa natureza podem também contribuir para detectar os problemas na relação usuário-tecnologia-informação, para que as instituições aprimorem a infra-estrutura de redes eletrônicas e de equipamentos e propiciem a capacitação de seu corpo docente para o uso efetivo da internet. Ou seja, contribuir para aprimorar os serviços de informação e comunicação prestados aos docentes no âmbito das instituições brasileiras, além de contribuir para a expansão do conhecimento sobre a comunicação científica no Brasil. 


\section{OBJETIVOS}

\section{Objetivo geral}

Conhecer a influência da internet nas atividades acadêmico-científicas da comunidade brasileira de docentes da área de saúde pública.

\section{Objetivos específicos}

Caracterizar o docente que atua nos programas brasileiros de pós-graduação em saúde pública em nível de mestrado e doutorado e o uso que faz da internet.

Identificar as alterações provocadas pelo o uso da internet nas atividades de pesquisa e ensino.

Identificar barreiras e expectativas quanto ao uso da internet no desenvolvimento de atividades acadêmico-científicas. 


\section{MÉTODOS}

\subsection{Universo de estudo}

Realizou-se estudo transversal, de natureza descritiva, com a população de docentes dos Programas de Pós-Graduação da Área de Saúde Coletiva, das instituições públicas brasileiras de ensino superior, cadastradas, em 2001, no Sistema DataCAPES* e que oferecem ambos os níveis de formação, mestrado e doutorado. Com essa delimitação, pretendeu-se obter uma população homogênea atuante na formação de novos pesquisadores. Partiu-se da premissa de que esse docente está profissionalmente em plena atuação em sua carreira universitária e, provavelmente, com forte envolvimento no uso da internet em suas atividades acadêmico-científicas.

Cabe, nesta etapa do presente trabalho, ressaltar que a Saúde Pública é campo de conhecimento científico que se ocupa da investigação com o precípuo objetivo de melhorar as condições de saúde da população. A pesquisa científica em saúde pública tem como objetivo o bem estar da população, interagindo, para esse fim, com inúmeros ramos do saber, caracterizando-se fortemente como campo multi e interdisciplinar.

\footnotetext{
*Banco de Dados Coleta (DataCAPES) que contém o módulo Estatísticas da Pós-Graduação, instrumento de avaliação dos programas de pós-graduação do país. Disponível no endereço eletrônico http://www.capes.gov.br. Especificamente os dados foram extraídos do item Perfil da Pós-Graduação, no Cadastro de Docentes, 2001.
} 
Visa a identificar novos problemas e a buscar soluções de aplicação dos conhecimentos adquiridos para a melhoria de saúde da população, incluindo seus aspectos sociais, e cabe aos órgãos governamentais resolvê-los à luz desses conhecimentos (ANDRADE 1992). No Brasil, a expressão saúde pública dá margem a discussões quanto a sua definição e tem sido veiculada, muitas vezes, de modo equivalente, como Saúde Coletiva, Medicina Social, Medicina Preventiva, Medicina Comunitária, entre outras. As diferentes conotações empregadas para a saúde pública ainda estão em discussão no âmbito acadêmico-científico, presente em vasta literatura publicada a respeito.

A CAPES (Coordenação de Aperfeiçoamento de Pessoal de Nível Superior) adota o termo saúde coletiva para denominar uma das áreas que compõem a chamada Grande Área de Ciências da Saúde. Nota-se que a denominação dos programas de pós-graduação da Área de Saúde Coletiva da CAPES reflete a conotação que cada instituição atribui à área de saúde pública.

Assim, foram identificados 24 Programas de Pós-Graduação em Saúde Coletiva no Brasil (ANEXO 1). Em 2001, eles representavam 4,6\% dos 503 programas da Grande Área de Ciências da Saúde, de acordo com as categorias da CAPES. A denominação dos 24 Programas e respectivos números totais são descritos a seguir: Programa de Pós-Graduação em Saúde Coletiva (dez), Programa de Pós-Graduação em Saúde Pública (seis), Programa de Pós-Graduação em Epidemiologia (três), Programa de Pós-Graduação em Saúde e Ambiente (dois), Programa de PósGraduação em Medicina Preventiva (um), Programa de Pós-Graduação em Saúde da Mulher e da Criança (um) e Programa de Pós-Graduação em Saúde na Comunidade 
(um). Segundo os relatórios da CAPES, esses programas representavam, em 2001, $6 \%$ dos cursos em nível de mestrado e 13\% em doutorado realizados no Brasil. Em 2001, os Programas em Saúde Coletiva absorveram 1.115 alunos de mestrado e 715 alunos de doutorado (CAPES 2002).

Desses 24 Programas, conforme pode ser verificado na Tabela 1, nove ofereciam ambos os níveis, mestrado e doutorado, todos sob a responsabilidade de instituições públicas.

Tabela 1 - Número de docentes incluídos nos Programas de Pós-Graduação, níveis de mestrado e doutorado, da Área Saúde Coletiva, cadastrados no sistema DataCAPES, no Brasil em 2001, segundo as instituições responsáveis.

\begin{tabular}{|c|c|c|c|c|}
\hline $\begin{array}{l}\text { Programas de Pós- } \\
\text { Graduação em }\end{array}$ & IES - Instituição de Ensino Superior & Nível & UF & $\begin{array}{l}\text { No. de } \\
\text { docentes }\end{array}$ \\
\hline \multirow[t]{2}{*}{ Epidemiologia } & UFRGS - Univ. Federal do Rio Grande do Sul & Mestrado & RS & 23 \\
\hline & & Doutorado & & \\
\hline \multirow[t]{2}{*}{ Epidemiologia } & UFPEL - Universidade Federal de Pelotas & Mestrado & RS & 11 \\
\hline & & Doutorado & & \\
\hline \multirow[t]{2}{*}{ Medicina Preventiva } & USP - Faculdade de Medicina & Mestrado & SP & 20 \\
\hline & & Doutorado & & \\
\hline \multirow[t]{2}{*}{ Saúde Coletiva } & UERJ - Instituto de Medicina Social & Mestrado & RJ & 36 \\
\hline & & Doutorado & & \\
\hline \multirow[t]{2}{*}{ Saúde Coletiva } & UNICAMP - Faculdade de Ciências Médicas & Mestrado & SP & 32 \\
\hline & & Doutorado & & \\
\hline \multirow[t]{2}{*}{ Saúde Coletiva } & UFBA - Instituto de Saúde Coletiva & Mestrado & BA & 24 \\
\hline & & Doutorado & & \\
\hline \multirow{2}{*}{$\begin{array}{l}\text { Saúde da Mulher e } \\
\text { da Criança }\end{array}$} & FIOCRUZ - Instituto Fernandes Figueira & Mestrado & RJ & 17 \\
\hline & & Doutorado & & \\
\hline \multirow[t]{2}{*}{ Saúde Pública } & USP - Faculdade de Saúde Pública & Mestrado & SP & 162 \\
\hline & & Doutorado & & \\
\hline \multirow[t]{2}{*}{ Saúde Pública } & FIOCRUZ - Escola Nacional de Saúde Pública & Mestrado & $\mathrm{RJ}$ & 110 \\
\hline & & Doutorado & & \\
\hline TOTAL & 9 Programas & & & 436 \\
\hline
\end{tabular}

Fonte: CAPES 2001a. 
Esses nove Programas de Pós-Graduação são vinculados a sete universidades e um a órgão do governo da área da saúde, a saber: Universidade de São Paulo (USP), com a Faculdade de Saúde Pública (FSP) e a Faculdade de Medicina (FM); Universidade Federal da Bahia (UFBa), com o Instituto de Saúde Coletiva (ISC); Universidade Estadual do Rio de Janeiro (UERJ), com o Instituto de Medicina Social (IMS); Universidade de Campinas (UNICAMP), com a Faculdade de Ciências Médicas (FCM); Universidade Federal do Rio Grande do Sul (UFRGS); Universidade Federal de Pelotas (UFPel); e Fundação Oswaldo Cruz (FIOCRUZ), com a Escola Nacional de Saúde Pública (ENSP) e o Instituto Fernandes Figueira (IFF). Esses Programas, oferecidos em sua maioria na região Sudeste (66,7\%), congregaram, em 2001, 436 docentes, que serviriam como base para o presente estudo (Tabela 1).

Para a identificação dos nomes dos docentes foi utilizado o Cadastro de Docentes da CAPES (2001b). Já para a localização dos endereços eletrônicos ou postais dos docentes identificados, foram utilizadas as seguintes fontes: Diretório dos Grupos de Pesquisa no Brasil (CNPq) em sua versão disponível em 2001; currículo do pesquisador oferecido pela Plataforma Lattes (Currículo Lattes) do CNPq; e consulta aos websites e às secretarias de pós-graduação das instituições envolvidas no estudo.

Dos 436 nomes de docentes identificados, não foram incluídos 64 : sete $(1,6 \%)$ nomes apareceram duplicados, e 57 (13,1\%) docentes foram excluídos por vários motivos, como aposentadoria, falecimento, afastamento e não localização de fonte para contato. Com isso, o universo de estudo foi composto por 372 docentes efetivamente contactados posteriormente (Tabela 2). 
Tabela 2 - Número de docentes identificados, em 2001, no Cadastro de Docentes da CAPES dos Programas de Pós-Graduação em Saúde Coletiva, número de docentes não localizados e número de docentes contactados, de acordo com a instituição a qual se vinculam.

\begin{tabular}{ccccccccccc}
\hline $\begin{array}{c}\text { Número de } \\
\text { Docentes }\end{array}$ & FSP & ENSP & UERJ & UNICAMP & UFBA & UFRGS & FM & IFF & UFPEL & TOTAL \\
\cline { 2 - 11 }$y$ & 162 & 110 & 36 & 32 & 24 & 23 & 20 & 17 & 11 & 436 \\
\hline Identificados & 39 & 23 & - & 1 & - & - & 1 & - & - & 64 \\
Não incluídos* & 39 & & & & & & & & \\
$\begin{array}{c}\text { Contactados } \\
\text { para participar } \\
\text { do estudo }\end{array}$ & 123 & 87 & 36 & 31 & 24 & 23 & 19 & 17 & 11 & 372 \\
\hline
\end{tabular}

*7 nomes duplicados; 57 docentes não pertencentes aos Programas

Vale destacar que houve certa dificuldade para o levantamento de dados no processo de identificação da população estudada e para a obtenção dos endereços dos docentes. Pôde-se observar certa discrepância entre os dados informados pelo Sistema CAPES, pelo Diretório dos Grupos de Pesquisa no Brasil (CNPq) em suas versões disponíveis em 2001, e o currículo do pesquisador, disponível pela Plataforma Lattes (Currículo Lattes) do CNPq. Além disso, confrontado essas informações com os dados dos websites das instituições envolvidas, observou-se que algumas delas não apresentavam informações atualizadas. Ou seja, há necessidade de padronização e atualização dos dados nas diferentes fontes de identificação de docentes no Brasil, principalmente em se tratando de informações on-line e de disponibilização pública, importantes para ser utilizadas em pesquisas, avaliações e serviços. 


\subsection{Coleta dos dados}

A coleta de dados foi realizada por meio de questionário auto-aplicável encaminhado por meio de correio eletrônico a cada um dos docentes selecionados.

Para evitar problemas de vírus, o questionário pôde ser preenchido e devolvido pelo docente via web, com internet disponibilizada em servidor UNIX, imune a vírus, não havendo necessidade, para o docente, de abrir arquivo algum em seu computador.

Para garantir a participação dos docentes eventualmente não-usuários da internet e atender àqueles que não puderam responder o questionário eletrônico, foram enviados questionários impressos por via postal.

\subsubsection{Instrumento de coleta de dados}

Para a elaboração do questionário, foram consultados trabalhos que pudessem subsidiar o conteúdo e a forma de distribuição das questões. Assim, dentre outros, fundamentaram a elaboração do instrumento de coleta de dados para a presente pesquisa os artigos de ANDRADE e col. (2000), sobre uso de novas tecnologias de informação em comunidade de docentes de instituição acadêmica brasileira na área de saúde pública; estudo de VOOBIJ, sobre o uso da web para a busca da informação científica em comunidades acadêmicas da Holanda; e artigo de BUDD e CONNAWAY (1997), sobre hábitos e atitudes referentes ao uso de redes eletrônicas acadêmicas nos Estados Unidos, além de artigos nos quais WANG (1999) utiliza o questionário eletrônico para obter dados de uso da internet na área de ciência da informação, e de ZHANG (1999), que aplicou questionário via web para caracterizar o uso de recursos eletrônicos para fins acadêmicos. 


\section{a) Questionário eletrônico}

O questionário eletrônico foi desenvolvido em padrão HTML (HyperText Markup Language) para web. O programa NetObjects Fusion 4.0 da Lotus, gerador de HTML, foi usado para que fossem criados códigos que permitissem controle das respostas a cada submissão. Também foi utilizado um programa baseado em linguagem ASP (Active Server Pages) para construção e desenvolvimento de aplicativos para páginas na web (ANEXO 2 DISQUETE), para que, quando o docente enviasse o questionário, o programa verificasse os erros no preenchimento. Os dados obtidos foram armazenados no Microsoft Excel, em servidor web, gerando banco de dados. Esse banco possibilita consulta por meio de qualquer item indexado, além de permitir apresentação dos dados na forma de tabelas e gráficos.

O questionário foi estruturado em quatro módulos, contendo questões fechadas e abertas, relacionados a seguir:

Módulo I - Características da população estudada. Destinado a identificar as características sociodemográficas e acadêmicas dos docentes estudados: faixa etária, formação na graduação e titulação acadêmica (mestrado e doutorado), áreas temáticas de atuação, vínculo institucional, regime de trabalho, tempo de atuação na pósgraduação e distribuição de tempo para as atividades acadêmicas. Os campos do questionário referentes à formação acadêmica (graduação, mestrado e doutorado) eram abertos para resposta livre do docente. Para a indicação de sua área temática de atuação, foi indicada ao docente a classificação do vocabulário DeCS (Descritores em Ciências da Saúde), desenvolvido pela BIREME, para a área de Saúde Pública (Categoria Saúde Pública - SP do DeCS), que engloba: Administração e Planejamento 
em Saúde, Epidemiologia e Bioestatística, Cuidados de Saúde, Nutrição, Desastres, Saúde Ambiental e Reforma do Setor Saúde.

Módulo II - Uso da internet. Destinado a identificar se os docentes fazem uso da internet, há quanto tempo a utilizam e com qual freqüência e quais recursos são mais demandados em suas atividades, como correio eletrônico (e-mail), www ou web, grupos e listas de discussão, salas de bate-papo ou chats, teleconferências e transferência de arquivos (FTP). Para cada um dos recursos, os docentes deveriam indicar se os utilizam, se os conhecem mas não os utilizam ou se os desconhecem. Nesse módulo, uma das questões abordou a percepção do docente quanto a seu nível de experiência no uso da internet. Também foram identificados os não-usuários da internet, os motivos que os levam a não utilizá-la e a possibilidade de vir a fazê-lo no futuro.

Módulo III - Uso da internet na pesquisa e no ensino. Destinado a identificar as influências da internet nas questões referentes ao desenvolvimento de suas atividades de pesquisas e de divulgação de seus estudos, bem como de suas atividades de ensino acadêmico-administrativas relativas ao ensino. Nesse módulo também foi identificada a existência de sites específicos para facilitar a comunicação das atividades de pesquisa e ensino desenvolvidas pelo docente. Esse módulo apresentou uma questão sobre o envolvimento do docente em atividades referentes à tecnologia do ensino à distância.

Módulo IV - Barreiras e expectativas quanto ao uso da internet. Visou a identificar os recursos tecnológicos disponíveis na instituição a qual o docente se vincula e quais as barreiras de infra-estrutura sistêmica e operacional encontradas para 
o uso da internet na sua instituição. Além disso, foram introduzidas questões para conhecer a opinião do docente e suas expectativas quanto ao futuro da internet como ferramenta para seu trabalho.

\section{b) Questionário impresso}

Para os docentes que não responderam o questionário eletrônico foi elaborado um modelo impresso que é uma cópia do eletrônico. Nesse questionário foi acrescentada uma questão para que o docente indicasse o motivo de ter utilizado o instrumento impresso. O questionário no formato impresso foi elaborado em programa da Microsoft Officer WORD 2000 (ANEXO 3). Os dados preenchidos pelo docente, nessa versão impressa, também foram inseridos no mesmo banco de dados criado para o questionário eletrônico, de forma a obter um único registro de todos os dados.

Cabe informar que o procedimento metodológico adotado para o presente estudo foi aprovado pelo Comitê de Ética em Pesquisa da Faculdade de Saúde Pública da Universidade de São Paulo, por ocasião da aprovação do projeto de pesquisa.

\subsubsection{Procedimento de envio dos questionários}

Do total de docentes selecionados (372), foram encontrados $359(96,5 \%)$ com endereços eletrônicos, para os quais foram encaminhados os questionários eletrônicos em março de 2002. Para os 13 (3,5\%) docentes cujos endereços eletrônicos não foram conseguidos, foram enviados na mesma época os questionários impressos, acompanhados de envelopes pré-selados para facilitar o envio da resposta.

Nas primeiras semanas após o envio, para os 359 e-mails enviados houve retorno de 149 questionários eletrônicos, ou seja, 41,5\%, e nenhum dos 13 impressos. 
Após 20 dias, foram enviados questionários no formato impresso a todos os 210 docentes que não responderam o eletrônico. Assim, o total de questionários impressos passou a ser de 223, sendo 13 na primeira remessa e 210, na segunda.

Dessa forma, dos 372 docentes selecionados, $237(63,7 \%)$ responderam ao questionário, sendo 149 (62,9\%) no formato eletrônico e 88 (37,1\%), no impresso, num período total de três meses de coleta de dados. A distribuição dos questionários enviados e respondidos encontra-se na Tabela 3.

Tabela 3 - Número de questionários impressos e eletrônicos enviados e respondidos pela população selecionada, no período de fevereiro a maio de 2002.

\begin{tabular}{|c|c|c|c|c|c|c|}
\hline \multirow[t]{2}{*}{ Instituições } & \multirow[t]{2}{*}{$\begin{array}{l}\text { Questionários } \\
\text { enviados }\end{array}$} & \multicolumn{2}{|c|}{$\begin{array}{c}\text { Questionários } \\
\text { respondidos }\end{array}$} & \multicolumn{2}{|c|}{ Total } & \multirow[t]{2}{*}{$\begin{array}{c}\text { Representação } \\
\text { por Instituição }\end{array}$} \\
\hline & & Eletrônicos & Impressos & No. & $\%$ & \\
\hline USP - FSP & 124 & 73 & 19 & 92 & 38,8 & $74,2 \%$ \\
\hline FIOCRUZ - ENSP & 87 & 32 & 12 & 44 & 18,6 & $50,6 \%$ \\
\hline UERJ - IMS & 36 & 5 & 14 & 19 & 8,0 & $52,8 \%$ \\
\hline UNICAMP - FMC & 31 & 8 & 9 & 17 & 6,8 & $54,8 \%$ \\
\hline UFBA - ISC & 24 & 6 & 7 & 13 & 5,5 & $54,2 \%$ \\
\hline UFRGS & 23 & 6 & 11 & 17 & 8,0 & $73,9 \%$ \\
\hline USP - FM & 19 & 11 & 8 & 19 & 8,0 & $100 \%$ \\
\hline FIOCRUZ -IFF & 17 & 3 & 7 & 10 & 4,2 & $58,8 \%$ \\
\hline UFPEL & 11 & 5 & 1 & 6 & 2,5 & $54,5 \%$ \\
\hline TOTAL & 372 & 149 & 88 & 237 & 100 & $63,7 \%$ \\
\hline
\end{tabular}


Verifica-se, na Tabela 3, que houve representação de mais da metade de cada comunidade docente das instituições abrangidas. A Faculdade de Medicina da USP teve a participação de todos os docentes identificados (100\%), seguida da Faculdade de Saúde Pública da USP e da Universidade Federal do Rio Grande do Sul, que tiveram representatividade de seus docentes de $74,2 \%$ e $73,9 \%$, respectivamente.

\subsection{Análise estatística}

A análise foi feita, descritivamente, por meio de proporções, médias e desviospadrão.

Foi feita a comparação entre o grupo de docentes que utiliza a internet e o grupo que não a usa, em relação a idade atual do docente, sua experiência na pósgraduação, área de conhecimento, regime de trabalho e porcentagem de tempo dedicado ao ensino e à pesquisa, utilizando o teste de associação pelo qui-quadrado.

\subsection{Questões éticas}

O procedimento metodológico adotado foi aprovado pelo Comitê de Ética em Pesquisa da Faculdade de Saúde Pública da Universidade de São Paulo, em 2001, por ocasião da aprovação do projeto da presente pesquisa. 


\section{RESULTADOS E DISCUSSÃO}

O presente estudo foi estruturado de forma a acrescentar algum conhecimento sobre o uso e as atitudes da comunidade acadêmica frente às novas tecnologias de informação. A seleção da população estudada recaiu nos docentes pesquisadores do campo da saúde pública que atuam, no Brasil, nos programas de pós-graduação de ambos os níveis, mestrado e doutorado.

O estudo realizado foi transversal, por se pretender conhecer as mudanças inseridas no meio acadêmico após cinco anos da introdução da internet e das novas tecnologias dela resultantes.

A contribuição deste estudo reside numa pequena parte do universo de necessidades de estudos sobre a internet e na sistematização de informações sobre o uso da rede internacional de computadores especificamente na comunidade acadêmica e na área do conhecimento de saúde pública no contexto brasileiro.

\subsection{Emprego do questionário via internet}

Observou-se que o método de coleta de dados por meio de questionário eletrônico respondido via web tende a obter o mesmo sucesso que o formato impresso. 
Nas primeiras semanas após o envio dos questionários, houve retorno de $41,5 \%$ aos questionários eletrônicos e nenhuma resposta ao impresso. Esse resultado está próximo dos índices encontrados na literatura levantada sobre instrumentos eletrônicos de coleta de dados para pesquisa. Vários trabalhos demonstram que o uso de questionários via internet têm índices de respostas semelhantes ao instrumento impresso (APPLEBEE 1997, LEIBSCHER e col. 1997, WEINGART e ANDERSON 2000, ZHANG 1999, ZHANG 2000). Em estudo específico sobre tempo e taxas de resposta de inquéritos eletrônicos, SHANNON e BRADSHAW (2002) encontraram taxa de retorno de $41 \%$ e também citaram estudo de metanálise sobre pesquisas com uso de questionários eletrônicos revelando taxa de retorno mais baixa $(39,6 \%)$ do que a média divulgada.

Sobre o tempo de resposta, ZHANG $(1999,2000)$ obteve mais retorno do instrumento via web do que do impresso nos primeiros dias subseqüentes ao envio, resultado corroborado pelo estudo de SHANNON e BRADSHAW (2000), com tempo de resposta muito mais rápido para o eletrônico. Nota-se que o respondente do meio eletrônico tende a fazê-lo de imediato; os que deixam para depois, dificilmente o fazem.

Dentre as vantagens do instrumento eletrônico, ABELS (1996) e SHANNON e BRADSHAW (2002) argumentam que essa forma, via e-mail, além de ser mais rápida, é menos dispendiosa que o serviço postal. Outra vantagem é não ficar restrita aos horários desses serviços. Os custos de elaboração e envio de questionários eletrônicos, se comparados com os aplicados à forma impressa, praticamente inexistem. No impresso estão envolvidas outras questões, como custos de impressão, 
papel, envelopes e postagem para o envio e a devolução pelo docente, além do tempo gasto para todo esse preparo.

A essas vantagens acrescenta-se o fato de o questionário eletrônico poder ter grande alcance geográfico, abrangendo muito mais respondentes (WANG 1999). No caso dos questionários elaborados em HTML para disponibilização na web, outro benefício é a possibilidade da criação de base de dados (PALMQUIST e KIM 1998), podendo ser respondido imediatamente via web-browsers (LUBANSKI e MATTHEW 1998).

A desvantagem do uso desse tipo de instrumento via web é excluir a população que não tem acesso a essa tecnologia. Nesse aspecto, vários estudos sobre uso de redes ainda adotam a forma impressa de questionário, como os de APPLEBEE e col (1997, 2000), que orientam o uso de instrumentos impressos para estudos que objetivem analisar a utilização de redes eletrônicas, como forma de alcançar os não usuários das redes.

\subsubsection{Forma de envio dos questionários eletrônicos}

Alguns pontos devem ser comentados quanto ao envio dos questionários eletrônicos. Um deles se refere à adequação da data escolhida para o envio das mensagens eletrônicas. No caso do presente estudo, foi determinada uma data de forma aleatória, que recaiu no período da tarde de uma sexta-feira. Num mesmo lote foram enviados 359 e-mails, contendo texto com link para acesso remoto ao questionário. Ocorre que, como em véspera de final de semana o uso da rede tende a ser mais intenso, o envio simultâneo dessas mensagens tornou lento o sistema de 
rede, acarrentando mais tempo que o previsto para a finalização de todo o processo de envio.

Outro ponto a considerar é a possibilidade de ocorrência de instabilidades na rede ou no servidor que hospedar o questionário eletrônico. No caso do presente estudo, ocorreram problemas operacionais no servidor da rede que acarretaram perdas de arquivos. As falhas puderam ser identificadas e solucionadas dois dias após o envio das mensagens, na segunda-feira. Essa ocorrência fez com que os registros dos questionários recebidos na sexta-feira e sábado fossem perdidos, sem que pudessem ser identificados os nomes desses respondentes. Na tentativa de recuperação desses questionários, foi enviada uma segunda mensagem a todos os docentes explicando o fato ocorrido e solicitando colaboração daqueles que já houvessem respondido o questionário, para que o respondessem novamente. Essa segunda resposta não pôde ser quantificada, mas alguns docentes afirmaram responder pela segunda vez, conforme observado em alguns comentários livres nos questionários e nos motivos alegados para o uso do impresso.

Deve-se atentar também a outros fatores que podem comprometer a resposta ao questionário eletrônico, como a devolução das mensagens enviadas. Por exemplo, várias instituições instalam bloqueadores de acesso para evitar vírus em suas redes; as caixas de correio dos respondentes podem estar com excesso de mensagens; o endereço eletrônico pode estar inativo ou grafado incorretamente, entre outros. No caso do presente trabalho, poucas mensagens assinalaram erro de envio, e, destas, todas puderam ser recuperadas. 


\subsubsection{Escolha pelo impresso ou eletrônico}

A maioria dos docentes respondentes (149) utilizou a forma eletrônica (62,9\%) para enviar suas repostas. Os demais $37,1 \%$ (88) utilizaram o instrumento impresso.

Os principais motivos alegados pelos 88 docentes para a utilização do instrumento impresso foram o não recebimento da mensagem eletrônica $(29,5 \%)$ e a falta de tempo para respondê-la $(19,3 \%)$ (Tabela 4). O excesso de mensagens nos correios eletrônicos foi mencionado por apenas $4,5 \%$ dos docentes, mas pode ter sido o motivo de quase um terço deles $(29,5 \%)$ não ter recebido a versão eletrônica.

Tabela 4 - Número e porcentagem sobre motivos alegados pelos docentes dos Programas de Pós-Graduação da área de saúde pública, no Brasil (2002), para responder o questionário impresso em vez do eletrônico.

\begin{tabular}{lcc}
\hline \multicolumn{1}{c}{ Motivo da utilização do impresso } & N & \% \\
\hline Não recebeu o questionário eletrônico & 26 & 29,5 \\
Não teve tempo para responder o eletrônico & 17 & 19,3 \\
Não abriu seus e-mails nesse período & 6 & 6,8 \\
Respondeu o eletrônico, que foi perdido por problemas no servidor & 6 & 6,8 \\
Excesso de mensagens na caixa de correio eletrônico & 4 & 4,5 \\
Outros motivos* & 9 & 10,3 \\
Não responderam & 20 & 22,8 \\
\hline Total & $\mathbf{8 8}$ & $\mathbf{1 0 0}$ \\
\hline
\end{tabular}

* "Não costumo responder a todas as solicitações por e-mail"; "Faltou informações sobre a pesquisa a ser realizada para que o docente se engajasse"; "Problemas com vírus no computador"; "Problemas com o equipamento"; "Não tive interesse em responder [eletrônico]"; "Não tenho e-mail”; "Esqueci-me e acabei perdendo o questionário"; "Estive fora do país por dois meses"; "Tempo solicitado para resposta não compatível com a disponibilidade". 
$\mathrm{Na}$ sua maioria em universidades, os docentes envolvidos com pesquisa e ensino têm seus endereços eletrônicos divulgados para acesso público nos websites das instituições, nos diretórios de pesquisa do CNPq, no Currículo Lattes, entre outros. Por isso, são freqüentemente bombardeados com inúmeras mensagens que, muitas vezes, nem chegam a ser abertas, ficando essa seleção dependente do tempo disponível. Vários e-mails costumam retornar com a notificação de que as caixas estão lotadas. Além disso, o excesso de mensagens acarreta falta de espaço destinado ao correio eletrônico, fazendo com que as mensagens recebidas pelo docente sejam devolvidas ao destinatário, como ocorreu em alguns casos deste estudo. Também retornaram mensagens devido a incorreções no endereço eletrônico utilizado.

Sobre respostas a questionários, ZHANG (2000), nos Estados Unidos, ao investigar o uso da internet por pesquisadores, não encontrou relação quanto a preferência pelo questionário impresso ou eletrônico para o envio de dados. Em seu universo pesquisado, encontrou que alguns utilizaram o formato impresso alegando a facilidade de poder respondê-lo em qualquer lugar, já que o papel à vista tende a ser respondido mais prontamente, sendo que o eletrônico ficaria restrito à disponibilidade de um computador.

Mesmo com todos os prós e contras, a preferência pelo questionário eletrônico acaba por predominar sobre o impresso quando se abrange população que utiliza redes eletrônicas, pois representa menor custo, maior rapidez no retorno e possibilidade de abrangência de maior número de respondentes, trazendo índices de retorno semelhantes ao impresso. 


\subsection{Caracterização da população estudada}

Para conhecer a influência da internet nas atividades acadêmico-científicas da comunidade brasileira de docentes da área de saúde pública, bem como as alterações provocadas pela inserção dessas novas tecnologias da informação no processo da comunicação científica, este trabalho procurou primeiramente caracterizar o docente que atua nessa área. Assim, a seguir serão comentadas as características sociodemográficas e acadêmicas dos docentes que atuam na área de saúde pública, especificamente nos Programas de Pós-Graduação em Saúde Coletiva, em nível de mestrado e doutorado, no Brasil.

\section{a) Faixa etária}

A maioria (91,9\%) dos docentes tem mais de 41 anos de idade. Destes, grande parte (75,9\%) encontra-se na faixa etária de 41 a 60 anos. Apenas três docentes têm menos de 30 anos (Tabela 5).

Tabela 5 - Número e porcentagem de docentes dos programas de pós-graduação da área de saúde pública, no Brasil (2002), segundo faixa etária.

\begin{tabular}{ccc}
\hline Faixa etária & $\mathbf{N}$ & \% \\
\hline $21-30$ & 3 & 1,3 \\
$31-40$ & 16 & 6,8 \\
$41-50$ & 93 & 39,2 \\
$51-60$ & 87 & 36,7 \\
61 ou + & 33 & 13,9 \\
Não responderam & 5 & 2,1 \\
\hline TOTAL & $\mathbf{2 3 7}$ & $\mathbf{1 0 0}$ \\
\hline
\end{tabular}


Comparando-se esse achado com os de ANDRADE, obtidos em 1992, verificase que a comunidade brasileira de docentes da área de saúde pública com idade superior a 40 anos vem aumentando. Outro trabalho de ANDRADE e col., realizado em 2003 com comunidade de docentes de instituição acadêmica brasileira em saúde pública, apresentou média de idade de 51,9 anos, com forte concentração na faixa etária de 50 a 69 anos.

MEADOWS (1999) argumenta que o fator idade somente é importante se atrelado ao período da vida profissional do docente em que há tendência para maior ou menor produtividade. O docente tende a produzir menos durante o período em que está se formando, passa por um período posterior de alta produtividade e depois por um de declínio, à medida que envelhece. Em relação ao uso de novas tecnologias, o autor argumenta que a produtividade científica e a área do conhecimento em que o pesquisador atua são fatores que influenciam mais no uso de computadores do que a idade.

No caso brasileiro, o pesquisador demora mais para se formar. Esse tempo leva, no mínimo, seis anos, considerando que o jovem pesquisador se dedique à pósgraduação logo após graduar-se. Em grande parte dos casos, e dependendo das normas adotadas nas instituições, essa formação pode durar até 13 anos.

Pode-se notar a possível ocorrência do envelhecimento dessa comunidade nos últimos dez anos. Também, caso seja ponderado o fato de a idade do docente poder caracterizar o período de produtividade acadêmica, conforme padrões internacionais apontados por MEADOWS (1999), a maior parte $(75,9 \%)$ da comunidade brasileira de 
docentes, que está entre 41 e 60 anos, encontra-se na idade de maior produção acadêmica.

\section{b) Local de atuação e de formação acadêmica do docente}

A maior parte dos cursos de pós-graduação no Brasil concentra-se nas universidades públicas (MEIS e col. 2003). No caso da área de saúde pública, os cursos vinculam-se totalmente a instituições públicas, sendo seus docentes vinculados principalmente às universidades $(80,1 \%)$ ou a órgãos do governo ligados à área da saúde, como o Ministério da Saúde (19,9\%).

A maioria das instituições abrangidas está na região Sudeste (85,1\%), principalmente no Estado de São Paulo e no do Rio de Janeiro, que detêm $61,5 \%$ dos Programas de Pós-Graduação em Saúde Coletiva (ANEXO 1). Essa região contribui significativamente no impulso do desenvolvimento de pesquisas científicas e na formação de novos pesquisadores no Brasil. Esse fato é reconhecido em outros trabalhos, como o de ANDRADE que, em 1992, analisando a comunidade científica brasileira de saúde pública, obteve que as regiões Sudeste e Sul detinham $81 \%$ da produção científica na área.

No entanto, cabe esclarecer que o predomínio da pós-graduação na Região Sudeste ocorre não somente no caso da saúde pública, mas em outras áreas do conhecimento. Em ciências sociais, por exemplo, VIANNA e col. (1998) afirmam que o eixo Rio-São Paulo é responsável por $89,3 \%$ das teses, com forte concentração na USP. Esta tem grande tradição na formação de pós-graduação, inclusive na área de saúde pública. As primeiras teses com abordagens epidemiólogicas estão registradas 
em 1925 e 1926, ainda na Faculdade de Medicina da USP, e, em 1948, já na Faculdade de Higiene e Saúde Pública da USP, estão as teses para obtenção de grau de Professor Titular*. A USP abriga, há muito tempo, programas de pós-graduação na área de saúde pública, inclusive os credenciados pela CAPES.

A maior parte dos docentes estudados formou-se e titulou-se no Brasil, concentrando-se na região Sudeste do país, conforme observado na Tabela 6, sendo na graduação $70,9 \%$, no mestrado, $71,1 \%$, e doutorado, $78,0 \%$. Nessa região, houve predominância do Estado de São Paulo para graduação $(47,7 \%)$, mestrado $(48,9 \%)$ e doutorado (78,0\%), seguido do Estado do Rio de Janeiro com 15,3\% para graduação, $21,1 \%$ para mestrado e $17,3 \%$ para doutorado.

Tabela 6 - Número de docentes dos Programas de Pós-Graduação em Saúde Coletiva no Brasil, 2002, segundo região geográfica da instituição onde ocorreu sua formação em graduação e pós-graduação.

\begin{tabular}{|c|c|c|c|c|c|c|c|c|}
\hline \multirow[b]{2}{*}{$\begin{array}{l}\text { Formação } \\
\text { acadêmica }\end{array}$} & \multicolumn{5}{|c|}{ Brasil - Região Geográfica } & \multirow[b]{2}{*}{$\begin{array}{l}\text { Sub- } \\
\text { Total }\end{array}$} & \multirow[t]{2}{*}{ Exterior } & \multirow[t]{2}{*}{ Total } \\
\hline & Sudeste & Sul & $\begin{array}{l}\text { Centro- } \\
\text { Oeste }\end{array}$ & Norte & Nordeste & & & \\
\hline & No. (\%) & No. (\%) & No. (\%) & $\begin{array}{l}\text { No. } \\
(\%)\end{array}$ & No. (\%) & No. $(\%)$ & No. (\%) & No. (\%) \\
\hline \multirow[t]{2}{*}{ Graduação* } & 144 & 16 & 16 & 3 & 11 & 190 & 13 & 203 \\
\hline & $(70,9)$ & $(7,9)$ & $(7,9)$ & $(1,5)$ & $(5,4)$ & $(93,6)$ & $(6,4)$ & $(100)$ \\
\hline \multirow[t]{2}{*}{ Mestrado** } & 138 & 4 & 6 & - & 7 & 155 & 39 & 194 \\
\hline & $(71,1)$ & $(2,1)$ & $(3,1)$ & & $(3,6)$ & $(79,9)$ & $(20,1)$ & (100) \\
\hline Doutorado** $^{\star *}$ & 167 & 5 & 2 & - & 7 & 181 & 33 & 214 \\
\hline * & $(78,0)$ & $(2,3)$ & $(0,9)$ & & $(3,3)$ & $(84,6)$ & $(15,4)$ & $(100)$ \\
\hline \multirow[t]{2}{*}{ Outra } & 19 & 2 & - & - & - & 21 & 30 & 76 \\
\hline & $(25,0)$ & $(2,6)$ & & & & $(27,6)$ & $(39,5)$ & (100) \\
\hline
\end{tabular}

* 34 não responderam ; ** 43 não responderam; *** 23 não responderam.

* Informação do acervo da Biblioteca da Faculdade de Saúde Pública da USP 
A formação e titulação dos docentes no exterior foi representada por $6,4 \%$ na graduação, $20,1 \%$ no mestrado e $15,4 \%$ no doutorado. Os países mais procurados para o mestrado foram os Estados Unidos (17), seguido de países da Europa Inglaterra (12) e França (7) - e o México (2). Para o doutorado, houve mais diversificação de países, com predomínio da Europa, com Inglaterra (16), França (7), Espanha (1) e Itália (1), seguida por Estados Unidos (6), Canadá (2) e México (2).

\section{c) Área de formação acadêmica e titulação na pós-graduação}

A característica multidisciplinar de que se reveste o campo da saúde pública é identificada nas diferentes áreas de formação de seus docentes, desde a graduação até a pós-graduação.

A maioria dos docentes estudados teve sua formação acadêmica básica em ciências biológicas, tanto na graduação como na titulação em mestrado e doutorado. Na graduação, houve predomínio para essa área em 75,6\% (Tabela 7). Os demais são representados pelas duas outras grandes áreas, ciências humanas (16,0\%) e exatas (8,9\%), que abrangeram 24,9\% da totalidade da população estudada.

Tabela 7 - Número e porcentagem de docentes dos programas de pós-graduação da área de saúde pública, Brasil (2002), segundo as áreas do conhecimento e sua formação acadêmica e titulação na pós-graduaçao.

\begin{tabular}{lcccc}
\hline \multirow{2}{*}{$\begin{array}{l}\text { Formação } \\
\text { acadêmica }\end{array}$} & \multicolumn{3}{c}{ Áreas do conhecimento } & \multirow{2}{*}{ Total } \\
\cline { 2 - 4 } & Biológicas & Humanas & Exatas \\
\cline { 2 - 4 } & No. (\%) & No. (\%) & No. (\%) & No. (\%) \\
\hline Graduação* & $170(75,6)$ & $36(16,0)$ & $20(8,9)$ & $231(100)$ \\
Mestrado** & $169(83,7)$ & $21(10,4)$ & $12(5,9)$ & $202(100)$ \\
Doutorado*** & $203(88,6)$ & $20(8,8)$ & $6(2,6)$ & $229(100)$ \\
\hline \multicolumn{2}{c}{ *12 não responderam; **35 não responderam; ***8 não responderam }
\end{tabular}


Observa-se, na Tabela 8, que na graduação houve a predominância da formação em medicina $(48,4 \%)$.

Tabela 8 - Número de docentes dos Programas de Pós-Graduação em Saúde Coletiva no Brasil, em 2001, segundo área de formação acadêmica em graduação.

\begin{tabular}{|c|c|c|}
\hline Graduação & No. & $\%$ \\
\hline Ciências Biológicas & 170 & 75,6 \\
\hline Biologia & 14 & 6,2 \\
\hline Enfermagem & 7 & 3,1 \\
\hline Farmácia e Bioquímica & 8 & 3,6 \\
\hline Medicina & 109 & 48,4 \\
\hline Medicina Veterinária & 4 & 1,8 \\
\hline Nutrição & 10 & 4,5 \\
\hline Odontologia & 12 & 5,3 \\
\hline Psicologia & 5 & 2,2 \\
\hline Química & 1 & 0,4 \\
\hline Ciências Humanas & 36 & 16,0 \\
\hline Administração & 1 & 0,4 \\
\hline Arquitetura & 1 & 0,4 \\
\hline Biblioteconomia & 1 & 0,4 \\
\hline Ciências Domésticas & 1 & 0,4 \\
\hline Ciências Políticas & 1 & 0,4 \\
\hline Ciências Sociais & 13 & 5,8 \\
\hline Direito & 2 & 0,9 \\
\hline Economia & 1 & 0,4 \\
\hline Educação & 2 & 0,9 \\
\hline Filosofia & 3 & 1,4 \\
\hline Geografia & 2 & 0,9 \\
\hline História & 2 & 0,9 \\
\hline Pedagogia & 3 & 1,4 \\
\hline Serviço Social & 3 & 1,4 \\
\hline Ciências Exatas & 20 & 8,9 \\
\hline Engenharia & 12 & 5,3 \\
\hline Estatística & 3 & 1,4 \\
\hline Física & 2 & 0,9 \\
\hline Matemática & 2 & 0,9 \\
\hline TOTAL & 225 & 100 \\
\hline
\end{tabular}

*12 não responderam

Esse resultado aproxima-se de estudo de 1992 de ANDRADE, em que 53,7\% dos docentes tinham formação médica, e do estudo mais recente de ANDRADE e col. 
(2003), no qual se observa que a maior concentração de docentes de uma instituição acadêmica da área de saúde pública era de médicos $(28,6 \%)$, seguida por nutricionistas $(9,1 \%)$ e por engenheiros $(7,8 \%)$ e farmacêuticos (7,8\%). Mesmo mantendo a primazia, nota-se que houve um declínio da área médica no campo da saúde pública nas últimas décadas.

Tanto para o mestrado (87,3\%) quanto para o doutorado $(88,6 \%)$, a concentração se dá para a área das ciências biológicas. No presente estudo, verificouse que a formação em ciências humanas foi apontada por 16,0\% da população estudada (Tabela 7). Corroborando essa afirmação, ANDRADE, em estudo realizado também em comunidade acadêmica de saúde pública em 1992, encontrou 10,4\% de pesquisadores formados na área de ciências sociais, o que sugere um aumento do interesse nessa área.

O mesmo acontece em relação às áreas a que esses docentes se dirigiram na pós-graduação. No mestrado, $83,7 \%$ dos docentes, conforme indicação livre deles próprios, direcionaram-se para a área das ciências biológicas (Tabela 7). As outras duas grandes áreas foram mencionadas por 16,3\% (33), sendo das ciências humanas, 10,4\% (21), e das exatas, 5,9\% (12). As indicações podem ser observadas no ANEXO 4.

No doutorado, da mesma forma, $88,6 \%$ das especialidades indicadas foram em ciências biológicas, 8,8\% em ciências humanas e 2,6\% em exatas (Tabela 7). As indicações dos docentes podem ser observadas no ANEXO 5.

Este é um reflexo do que ocorre no ensino de pós-graduação no Brasil, ou seja, segundo dados da CAPES (2001b), a área das ciências da saúde concentra o maior 
número de programas de pós-graduação (37\%), seguida pelas ciências humanas $(13 \%)$.

\section{d) Especialidade temática}

Na tentativa de verificar em qual área temática o docente atua nos dias de hoje, foi apresentada no questionário uma classificação temática para que ele próprio se enquadrasse quanto à sua área de especialização.

A classificação proposta para escolha do docente foi o vocabulário DeCS-SP (Descritores em Ciências da Saúde, categoria Saúde Pública) da BIREME, assinalada por 146 docentes, que indicaram com maior destaque as categorias Epidemiologia e Bioestatística $(27,8 \%)$ e Administração e Planejamento de Saúde (21,9\%), totalizando 49,7\% (Tabela 9).

Tabela 9 - Número e porcentagem de docentes dos programas de pós-graduação da área de saúde pública no Brasil (2002), segundo especialidade temática de acordo com a classificação do DeCS- Descritores em Ciências da Saúde.

\begin{tabular}{|c|c|c|}
\hline Categoria SP - Saúde Pública & $\mathrm{N}^{0}$ de docentes & $\%$ \\
\hline Administração e planejamento em saúde & 52 & 21,9 \\
\hline Cuidados de saúde & 11 & 4,6 \\
\hline Saúde Ambiental & 38 & 16,0 \\
\hline Epidemiologia e Bioestatística & 66 & 27,8 \\
\hline Nutrição & 15 & 6,3 \\
\hline Reforma do setor saúde & 2 & 0,8 \\
\hline Demografia & 3 & 1,3 \\
\hline Desastres & - & - \\
\hline Outras** & 30 & 12,7 \\
\hline Não responderam & 20 & 8,4 \\
\hline TOTAL & 237 & 100 \\
\hline
\end{tabular}

* a relação das outras especialidades indicadas encontra-se no ANEXO 6 
Cabe mencionar que, no questionário, na relação dos termos DeCS oferecidos para a seleção do docente, não havia a definição e a abrangência de cada um deles. Este pode ter sido o motivo de vários docentes terem assinalado mais de uma opção (havia possibilidade de múltipla escolha) para indicar sua especialidade temática. A Tabela 9 apresenta todas as indicações assinaladas pelos que responderam essa questão, sendo que 187 (78,9\%) docentes escolheram as opções da categoria DeCSSP, e 30 (12,7\%) indicaram outras opções não contempladas na categoria Saúde Pública (SP) do DeCS, mas que aparecem em outras categorias desse vocabulário. As indicações estão relacionadas no ANEXO 6.

\section{e) Tempo e forma de dedicação às atividades acadêmicas}

Os resultados mostraram que a população selecionada para este estudo tem grande experiência na vida acadêmica, por se dedicar ao ensino e à orientação na pósgraduação há mais de 10 anos, conforme assinalado por 46,8\% dos respondentes (Tabela 10).

Tabela 10 - Número e porcentagem de docentes dos programas de pós-graduação da área de saúde pública, no Brasil (2002), segundo o período de tempo que o docente vem atuando na pós-graduação.

\begin{tabular}{lcc}
\hline \multicolumn{1}{c}{ Período } & N de docentes & $\%$ \\
\hline$<1$ ano & 4 & 1,7 \\
1 a 5 anos & 63 & 26,6 \\
6 a 10 anos & 49 & 20,7 \\
$>10$ anos & 111 & 46,8 \\
Não responderam & 10 & 4,2 \\
\hline TOTAL & $\mathbf{2 3 7}$ & $\mathbf{1 0 0}$ \\
\hline
\end{tabular}


Corroborando esse dado, a maioria (81,0\%) dos docentes pesquisadores brasileiros exerce suas atividades acadêmicas em regime de tempo integral, dedicando-se exclusivamente ao ensino, à pesquisa e à extensão em suas instituições de origem (Tabela 11). Esse achado é semelhante ao estudo de ANDRADE, em 1992, com população de docentes da área de saúde pública no Brasil, pelo qual encontrou $85,8 \%$ de professores vinculados a esse regime.

Tabela 11 - Número e porcentagem de docentes dos programas de pós-graduação da área de saúde pública no Brasil (2002), segundo regime de trabalho na instituição a qual se vincula.

\begin{tabular}{lrc}
\hline \multicolumn{1}{c}{ Regime } & $\mathbf{N}^{\mathbf{0}}$ & $\%$ \\
\hline Tempo integral 40h/semana & 192 & 81,0 \\
Turno completo 24h/semana ou equivalente & 16 & 6,8 \\
Tempo parcial 12h/semana ou equivalente & 5 & 2,1 \\
Outro & 24 & 10,1 \\
\hline TOTAL & $\mathbf{2 3 7}$ & $\mathbf{1 0 0}$ \\
\hline
\end{tabular}

Em conseqüência desse regime de trabalho, a comunidade estudada dedica grande parte de seu tempo à pesquisa científica (Tabela 12), com 124 (52,3\%) docentes despendendo $40 \%$ a $60 \%$ de seu tempo e $93(39,2 \%)$ docentes empregando metade o3u mais de seu tempo. Apenas 5,5\% (13) dedicam mais da metade de seu tempo no ensino. Assim, observa-se que o docente dedica menos tempo ao ensino do que à pesquisa. Esse fato pode ser comprovado quando a maioria (159 - 67,1\%) informou dedicar $10 \%$ a $30 \%$ de seu tempo ao ensino. 
$60-$

Quanto às atividades de extensão e administrativas, a concentração do tempo despendido está entre os menores percentuais. O docente dedica até $20 \%$ de seu tempo em atividades de extensão $(53,2 \%)$ e de administração acadêmica $(59,5 \%)$.

Tabela 12 - Número de docentes dos programas de pós-graduação da área de saúde pública, no Brasil (2002), segundo a porcentagem de distribuição do tempo de trabalho para as suas atividades acadêmico-científicas.

Porcentagem da distribuição do tempo de trabalho dos docentes

Atividades

\begin{tabular}{|c|c|c|c|c|c|c|c|c|c|c|c|c|}
\hline & $10 \%$ & $20 \%$ & $30 \%$ & $40 \%$ & $50 \%$ & $60 \%$ & $70 \%$ & $80 \%$ & $90 \%$ & $\begin{array}{c}100 \\
\%\end{array}$ & $\begin{array}{l}\text { Não } \\
\text { Resp }\end{array}$ & Total \\
\hline Ensino & 33 & 47 & 79 & 37 & 14 & 9 & 1 & 3 & - & - & 14 & 237 \\
\hline Pesquisa & 14 & 24 & 46 & 50 & 40 & 34 & 12 & 6 & 1 & - & 10 & 237 \\
\hline Extensão & 88 & 38 & 24 & 9 & 5 & - & - & - & - & - & 73 & 237 \\
\hline $\begin{array}{l}\text { Administr } \\
\text { ativas }\end{array}$ & 106 & 35 & 15 & 11 & 5 & - & 3 & 1 & - & - & 61 & 237 \\
\hline
\end{tabular}

Nesse aspecto, os docentes, ao evoluírem na carreira, geralmente tendem a receber responsabilidades e encargos administrativos adicionais que podem influir nas demais atividades acadêmico-científicas (MEADOWS 1999). No entanto, esse dado deve ser objeto de estudos na comunidade de docentes da área de saúde pública, pois, de acordo com MEADOWS (1999), ao contrário do que parece acontecer, os pesquisadores mais dedicados, que além da pesquisa se engajam também no ensino ou na administração acadêmica, podem ser mais produtivos do que os que se concentram exclusivamente na pesquisa. 


\subsection{Uso da internet pela comunidade estudada}

A internet foi disponibilizada no Brasil a partir de 1995, passando desde então a fazer parte das atividades das comunidades científicas brasileiras. Essa afirmativa é confirmada pelos resultados desta pesquisa, já que, no universo de $94,9 \%$ de docentes que usam a internet, mais da metade (61,6\%) já a utiliza há mais de cinco anos (Tabela 13).

Tabela 13 - Número e porcentagem de docentes dos programas de pós-graduação em saúde pública, Brasil (2002), de acordo com o período de tempo que utilizam a internet para atividades acadêmico-científicas.

\begin{tabular}{ccc}
\hline Período & $N^{\circ}$ de docentes & $\%$ \\
\hline$<1$ ano & 3 & 1,3 \\
1 ou 2 anos & 8 & 3,6 \\
3 ou 4 anos & 52 & 23,1 \\
$>5$ anos & 139 & 61,8 \\
Não responderam & 23 & 9,7 \\
\hline TOTAL & $\mathbf{2 2 5}$ & $\mathbf{1 0 0 , 0}$ \\
\hline
\end{tabular}

A maioria desses docentes considera dominar o uso da internet $(73,8 \%)$ (Tabela 14). Dessa forma, fica difícil imaginar que esse fato não tenha trazido transformações no dia-a-dia da comunidade acadêmico-científica brasileira. 
Tabela 14 - Número de docentes dos Programas de Pós-Graduação em Saúde Coletiva, 2002, segundo seu nível de experiência com o uso da internet em suas atividades acadêmicocientíficas.

\begin{tabular}{|c|c|c|}
\hline Experiência & $\mathrm{N}^{\circ}$ de docentes & $\%$ \\
\hline Um iniciante & 33 & 14,7 \\
\hline Com domínio das principais ferramentas & 137 & 60,9 \\
\hline Com domínio total & 29 & 12,9 \\
\hline Não responderam & 26 & 11,5 \\
\hline TOTAL & 225 & 100,0 \\
\hline
\end{tabular}

\subsubsection{Uso dos recursos da internet}

Dentre os recursos da internet, o correio eletrônico é o mais utilizado pela grande maioria (96,9\%) (Tabela 15), sendo que, desta, $87,3 \%$ o fazem diariamente. A web aparece em segundo lugar de uso (91,1\%), com navegação diária apontada por $55,6 \%$ dos docentes. O resultado obtido em relação à preferência pelo uso dos recursos correio eletrônico e web foi semelhante ao da grande maioria dos trabalhos levantados. LALLY (2001) afirma que mesmo os pesquisadores da área de ciências sociais, que utilizam menos as tecnologias da internet, já consideram esses dois recursos os pilares da infra-estrutura para pesquisa no ambiente eletrônico.

Os demais serviços da internet são pouco utilizados pelos docentes estudados, exceto a transferência de arquivos (FTP), que é utilizada por $64,9 \%$ dos docentes, com maior freqüência no uso semanal $(25,3 \%)$ do que no diário $(17,3 \%)$, conforme Tabela 15. Entretanto, 14 docentes $(6,2 \%)$ desconheciam esse recurso. 
Tabela 15 - Número e porcentagem de docentes dos programas de pós-graduação da área de saúde pública no Brasil (2002), segundo seu conhecimento e uso dos recursos da internet.

\begin{tabular}{|c|c|c|c|c|c|c|c|}
\hline \multirow{3}{*}{$\begin{array}{c}\text { Recursos } \\
\text { da } \\
\text { internet }\end{array}$} & \multirow{3}{*}{$\begin{array}{c}\text { Desconhece } \\
\text { No. } \\
(\%) \\
\end{array}$} & \multirow{2}{*}{$\begin{array}{l}\text { Conhece } \\
\text { e não } \\
\text { utiliza } \\
\end{array}$} & \multicolumn{4}{|c|}{ Uso da internet } & \multirow{2}{*}{ Não resp } \\
\hline & & & diário & semanal & mensal & anual & \\
\hline & & $\begin{array}{l}\text { No. } \\
(\%) \\
\end{array}$ & $\begin{array}{l}\text { No. } \\
(\%)\end{array}$ & $\begin{array}{l}\text { No. } \\
(\%) \\
\end{array}$ & $\begin{array}{l}\text { No. } \\
(\%) \\
\end{array}$ & $\begin{array}{l}\text { No. } \\
(\%)\end{array}$ & $\begin{array}{l}\text { No. } \\
(\%)\end{array}$ \\
\hline $\begin{array}{l}\text { Correio eletrônico } \\
\text { (e-mail) }\end{array}$ & - & - & $\begin{array}{c}207 \\
(92,0)\end{array}$ & $\begin{array}{c}9 \\
(4,0)\end{array}$ & $\begin{array}{c}1 \\
(0,4)\end{array}$ & $\begin{array}{c}1 \\
(0,4)\end{array}$ & $\begin{array}{c}7 \\
(3,1)\end{array}$ \\
\hline $\begin{array}{l}\text { WWW - World } \\
\text { Wide Web (sites) }\end{array}$ & $\begin{array}{c}1 \\
(0,4)\end{array}$ & $\begin{array}{c}3 \\
(1,3)\end{array}$ & $\begin{array}{c}125 \\
(55,6)\end{array}$ & $\begin{array}{c}66 \\
(29,3)\end{array}$ & $\begin{array}{c}14 \\
(6,2)\end{array}$ & - & $\begin{array}{c}16 \\
(7,1)\end{array}$ \\
\hline $\begin{array}{l}\text { Newsgroups - } \\
\text { Grupos e Listas } \\
\text { de Discussão }\end{array}$ & $\begin{array}{c}10 \\
(4,4)\end{array}$ & $\begin{array}{c}108 \\
(48,0)\end{array}$ & $\begin{array}{c}23 \\
(10,2)\end{array}$ & $\begin{array}{c}30 \\
(13,3)\end{array}$ & $\begin{array}{c}24 \\
(10,7)\end{array}$ & $\begin{array}{c}5 \\
(2,2)\end{array}$ & $\begin{array}{c}25 \\
(11,1)\end{array}$ \\
\hline $\begin{array}{l}\text { Salas de bate- } \\
\text { papo (chats, ICQ) }\end{array}$ & $\begin{array}{c}14 \\
(6,2)\end{array}$ & $\begin{array}{c}152 \\
(67,6)\end{array}$ & $\begin{array}{c}3 \\
(1,3)\end{array}$ & $\begin{array}{c}7 \\
(3,1)\end{array}$ & $\begin{array}{c}7 \\
(3,1)\end{array}$ & $\begin{array}{c}5 \\
(2,2)\end{array}$ & $\begin{array}{c}37 \\
(16,4)\end{array}$ \\
\hline Teleconferências & $\begin{array}{c}18 \\
(8,0)\end{array}$ & $\begin{array}{c}140 \\
(62,2)\end{array}$ & - & $\begin{array}{c}1 \\
(0,4)\end{array}$ & $\begin{array}{c}10 \\
(4,4)\end{array}$ & $\begin{array}{c}18 \\
(8,0)\end{array}$ & $\begin{array}{c}38 \\
(16,9)\end{array}$ \\
\hline $\begin{array}{l}\text { FTP - } \\
\text { Transferência e } \\
\text { obtenção de } \\
\text { arquivos }\end{array}$ & $\begin{array}{c}14 \\
(6,2)\end{array}$ & $\begin{array}{c}40 \\
(17,8)\end{array}$ & $\begin{array}{c}39 \\
(17,3) \\
\end{array}$ & $\begin{array}{c}57 \\
(25,3)\end{array}$ & $\begin{array}{c}36 \\
(16,0)\end{array}$ & $\begin{array}{c}12 \\
(5,3)\end{array}$ & $\begin{array}{c}27 \\
(12,0)\end{array}$ \\
\hline
\end{tabular}

* porcentagem calculada em relação aos 225 docentes que usam a Internet

Além do correio eletrônico e da web, recursos importantes que permitem comunicação em tempo real não são utilizados pela maioria dos docentes. Eles desconhecem - ou conhecem, mas não utilizam - os chats $(73,8 \%)$ e as teleconferências (70,2\%). Quanto aos grupos e às listas de discussão, poucos docentes desconhecem esses recursos (4,4\%), porém muitos não os utilizam $(48,0 \%)$. Embora tenham sido considerados veículos rápidos de comunicação, revelaram-se pouco úteis para a comunidade estudada (Tabela 15). 
Estudos em outras comunidades acadêmicas apresentam índices semelhantes, como o de COBB e BAIRD (1999) na área de enfermagem, com apenas 2\% dos pesquisadores utilizando chats e $3 \%$, os grupos de discussão. No entanto, outros estudos (APPLEBLEE 1997, LIEBSCHER e col.1997, SELWYN 2000) apontam para um crescimento no uso de grupos e listas de discussão nas comunidades acadêmicas.

\subsection{Não-usuários da internet da comunidade estudada}

Os resultados desta pesquisa mostraram que, dos 12 docentes que não utilizavam a internet, quase todos $(91,7 \%)$ cogitavam a possibilidade de vir a fazê-lo a curto ou a médio prazos. Apenas um docente não considerou a possibilidade de usá-la futuramente (Tabela 16).

Tabela 16 - Número e porcentagem de docentes não usuários da internet, dos programas de pós-graduação da área de em saúde pública, no Brasil (2002), segundo possibilidade de uso futuro da internet.

\begin{tabular}{|c|c|c|}
\hline $\begin{array}{c}\text { Possibilidade de uso da } \\
\text { internet }\end{array}$ & $\mathrm{N}^{\circ}$ de docentes & $\%$ \\
\hline A curto prazo & 6 & 50,0 \\
\hline A médio prazo & 5 & 41,7 \\
\hline A longo prazo & - & - \\
\hline Nenhuma possibilidade & 1 & 8,3 \\
\hline TOTAL & 12 & 100,0 \\
\hline
\end{tabular}

Pelos estudos levantados, verificou-se que, embora a maioria dos membros das comunidades acadêmicas afirmassem ser usuários da internet, consideravam-se iniciantes nessa tecnologia e viam possibilidade positiva de tornarem-se usuários experientes no decorrer do tempo (VOORBIJ 1999). 
SAVOLAINEN (2000), considerando os fatores que levam uma pessoa a querer iniciar o uso da internet, afirmou que a necessidade de um novo aprendizado e a falta de motivação são barreiras para esse objetivo. Nesse sentido, no presente trabalho, os motivos que levaram ao não uso da internet pelos docentes estiveram geralmente relacionados à falta de infra-estrutura $(16,7 \%)$ e de habilidade para esse fim $(58,3 \%)$, além de questões particulares de aversão à tecnologia $(33,3 \%)$ (Tabela 17). Notou-se a falta de motivação para usar a internet quando alguns docentes declararam que "conseguem o que precisam da internet com outras pessoas" (58,3\%), não considerando necessário aprender a usá-la. Também na questão falta de motivação está a afimação de que "conseguem o que precisam sem ter de usar a internet" $(66,7 \%)$, podendo-se acreditar que outras pessoas o fazem por eles, uma vez que muitas das atividades de pesquisa e de ensino carecem do uso da internet, como o curriculo Lattes, ou do acesso a bases de dados bibliográficas e textos completos, além de comunicações administrativas em geral.

Tabela 17 -Número e porcentagem de motivos do não uso da internet, segundo opinião dos docentes dos programas de pós-graduação da área de saúde pública, no Brasil (2002).

\begin{tabular}{lcc}
\hline \multicolumn{1}{c}{ Motivo } & No. & \%* \\
\hline Não conto com os equipamentos necessários funcionando em rede & 2 & 16,7 \\
Não tenho conhecimento suficiente de informática para o uso da internet & 4 & 33,3 \\
Ainda não sei navegar na Internet & 3 & 25,0 \\
Ainda não me adaptei a essas novas tecnologias & 4 & 33,3 \\
Consigo o que preciso sem ter de usar a internet & 8 & 66,7 \\
Consigo o que preciso da internet por meio de "colaboradores" & 7 & 58,3 \\
\hline
\end{tabular}

*porcentagem calculada em relação aos 12 docentes que referiram não usar a internet 
Em estudo nacional realizado na Holanda (VOORBIJ 1999), verificou-se que a maioria dos membros da comunidade acadêmica considerava-se com experiência no uso da internet, além de não precisar de treinamentos para manter-se atualizados. No entanto, essa comunidade argumentava que, para usar os recursos da internet, havia grande necessidade de explicações, considerando falsa a afirmação de que seu uso seja amigável. Portanto, pode-se dizer que a não utilização da internet no dia-a-dia dos docentes deva-se principalmente à falta de motivação.

\subsection{Fatores associados ao uso da Internet}

Do total de docentes analisados (237), 225 (94,9\%) usam a internet em suas atividades acadêmico-científicas. Das variáveis analisadas, idade atual, área do conhecimento, regime de trabalho e tempo dedicado às atividades de ensino e de pesquisa estiveram associadas, estatisticamente, ao uso da internet. Os detalhes dessa análise serão apresentados a seguir.

\subsubsection{Uso da internet e faixa etária e experiência acadêmica}

Dos docentes com 60 anos ou menos (204), apenas 2,9\% não utilizam a internet. Já dos docentes com mais de 60 anos (33), 18,2\% não a usam (Tabela 18), havendo associação significativa entre a idade do docente e uso da internet $(p=0,001)$. 
Tabela 18 - Número e porcentagem de docentes dos programas de pós-graduação da área de saúde pública, no Brasil (2002), segundo faixa etária do docente e o uso da internet.

\begin{tabular}{|c|c|c|c|c|c|c|}
\hline \multirow[t]{3}{*}{ Faixa etária } & \multicolumn{4}{|c|}{ Internet } & \multicolumn{2}{|c|}{ Total } \\
\hline & \multicolumn{2}{|c|}{ Usa } & \multicolumn{2}{|c|}{ Não usa } & \multirow[b]{2}{*}{ No. } & \multirow[b]{2}{*}{$\%$} \\
\hline & $\mathrm{N}^{\mathrm{O}}$ & $\%$ & No. & $\%$ & & \\
\hline Até 60 & 198 & 97,1 & 6 & 2,9 & 204 & 100 \\
\hline$>60$ & 27 & 81,6 & 6 & 18,2 & 33 & 100 \\
\hline TOTAL & 225 & 94,9 & 12 & 5,1 & 237 & 100 \\
\hline
\end{tabular}

$\mathrm{P}=0,001$

As questões idades do pesquisador e uso das novas tecnologias têm sido discutidas em vários estudos. Em 1987, quando foram realizados os primeiros estudos sobre o uso de redes eletrônicas (ROSEN e col.), esperava-se que o acadêmico mais idoso usasse menos a internet que o colega mais jovem. Porém, essa mesma pesquisa e os achados de ROSSEAU e ROGERS (1998) ponderam que acadêmicos mais velhos não diferem dos mais novos quanto ao uso, às atitudes ou à "posição" em relação a computadores. Corroborando esse aspecto, recentemente, alguns estudos têm comprovado que não há relação entre a idade e o uso da internet (APPLEBEE e col. 1997), embora sejam recomendados estudos mais sistematizados a respeito. Apenas ZHANG (1999), nos Estados Unidos, destacou que os que usam com mais freqüência e com mais habilidade são os mais jovens, numa faixa etária em média de 45,4 anos, cuja experiência de uso fica em torno de 5 a 9 anos.

No Brasil, um dos poucos trabalhos brasileiros que relacionam a idade do pesquisador da área de saúde pública ao uso das novas tecnologias é o de ITURRI 
(1998), no qual comenta que docentes de instituições acadêmicas, por terem em torno de 50 anos, vêem pouca vantagem em fazer inovações em novas tecnologias, uma vez que estão no final de suas carreiras.

O teste estatístico de associação demonstrou não haver relação entre o tempo em que o docente atua na pós-graduação e o uso da internet (Tabela 19). Ou seja, entre os que não usam a internet (12), não houve associação significativa $(p=0,533)$ entre o fato de o docente atuar há mais ou a menos de seis anos nas atividades da pós-graduação.

Tabela 19 - Número e porcentagem de docentes dos programas de pós-graduação em saúde pública, no Brasil (2002), segundo tempo de atuação na pós-graduação e uso da internet.

\begin{tabular}{|c|c|c|c|c|c|c|}
\hline \multirow{3}{*}{$\begin{array}{l}\text { Tempo na pós- } \\
\text { graduação }\end{array}$} & \multicolumn{4}{|c|}{ Internet } & \multirow{2}{*}{\multicolumn{2}{|c|}{ Total }} \\
\hline & \multicolumn{2}{|c|}{ Usa } & \multicolumn{2}{|c|}{ Não usa } & & \\
\hline & $\mathrm{N}^{\circ}$ & $\%$ & No. & $\%$ & No. & $\%$ \\
\hline Até 5 anos & 62 & 92,5 & 5 & 7,5 & 67 & 100 \\
\hline Mais de 6 anos & 153 & 95,6 & 7 & 4,4 & 160 & 100 \\
\hline TOTAL & 215 & 94,7 & 12 & 5,3 & 237 & 100 \\
\hline
\end{tabular}

$P=0,533$

\subsubsection{Uso da internet e área do conhecimento}

De acordo com a literatura pesquisada, parece haver relação entre a área do conhecimento que o pesquisador atua e a habilidade no uso das novas tecnologias, e, na presente pesquisa, essa relação pôde ser verificada. 
Houve associação significativa entre o uso da internet e a área do conhecimento, havendo maior porcentagem $(8,1 \%)$ de não-usuários na área de humanas (Tabela 20).

Tabela 20 - Número e porcentagem de docentes dos programas de pós-graduação da área de saúde pública no Brasil (2002), de acordo com a área em que atuam e o uso da internet.

\begin{tabular}{lccccccc}
\hline Área do conhecimento & \multicolumn{3}{c}{ Internet } & \multicolumn{2}{c}{ Total } \\
\cline { 2 - 6 } & \multicolumn{3}{c}{ Usa } & \multicolumn{2}{c}{ Não usa } \\
& $N^{0}$ & $\%$ & No. & $\%$ & No. & $\%$ \\
\cline { 2 - 6 } Biológicas & 163 & 95,3 & 8 & 4,7 & 171 & 100 \\
Exatas & 18 & 94,7 & 1 & 5,3 & 19 & 100 \\
Humanas & 34 & 91,9 & 3 & 8,1 & 37 & 100 \\
\hline TOTAL & 215 & 94,9 & 12 & 5,1 & 227 & 100 \\
\hline \multicolumn{1}{c}{$\mathrm{P}<0,001$} & & & & & &
\end{tabular}

Estudos sobre a relação entre o uso de redes eletrônicas e as áreas do conhecimento são pouco comentados na literatura publicada. Apenas VOORBIJ, em 1999, estudando áreas de pesquisa, encontrou relação entre o menor uso da internet e a área de humanidades. Relato similar foi o de BUDD e CONNAWAY (1997), que, em estudo sobre hábitos e atitudes de acadêmicos de universidades dos Estados Unidos, nas áreas de química, física, sociologia, psicologia, história e inglês, perceberam que os pesquisadores da área de ciências sociais usam menos as tecnologias disponíveis, porém utilizam muito mais o correio eletrônico para a comunicação informal e obtenção de elementos para suas pesquisas. Também o estudo de WALSH e col. (2000) encontrou predomínio do uso da internet pelos pesquisados americanos das áreas de 
física e matemática, mais que os de sociologia ou biologia. Outros estudos, como o de APPLEBEE e col. (2000), corroboram esse aspecto, indicando que os acadêmicos da área de humanidades e ciências sociais tendem a absorver mais lentamente as novas tecnologias, porém são usuários entusiásticos do correio eletrônico e da web.

\subsubsection{Uso da internet e regime de trabalho e distribuição do tempo para atividades acadêmico-científicas}

A Tabela 21 mostra que, dos 225 docentes que usam a internet, 97,4\% dedicam-se exclusivamente ao ensino e à pesquisa. Houve associação estatisticamente significativa entre o fato do docente estar fortemente envolvido nas atividades acadêmicos-científicas e fazer uso da internet. Ou seja, 40\% dos docentes que trabalham em regime de tempo parcial não usam a internet $(p<0,001)$ (Tabela 21).

Tabela 21 - Número e porcentagem de docentes dos programas de pós-graduação da área de saúde pública no Brasil (2002), segundo regime de trabalho na instituição a qual se vincula.

\begin{tabular}{|c|c|c|c|c|c|c|}
\hline \multirow[t]{3}{*}{ Regime de trabalho } & \multicolumn{4}{|c|}{ Internet } & \multicolumn{2}{|c|}{ Total } \\
\hline & \multicolumn{2}{|c|}{ Usa } & \multicolumn{2}{|c|}{ Não usa } & \multirow[b]{2}{*}{ No. } & \multirow[b]{2}{*}{$\%$} \\
\hline & $\mathrm{N}^{\mathrm{O}}$ & $\%$ & No. & $\%$ & & \\
\hline Tempo integral 40h/semana & 187 & 97,4 & 5 & 2,6 & 192 & 100 \\
\hline $\begin{array}{l}\text { Turno completo } 24 \mathrm{~h} / \text { semana ou } \\
\text { equivalente }\end{array}$ & 14 & 87,5 & 2 & 12,5 & 16 & 100 \\
\hline $\begin{array}{l}\text { Tempo parcial } 12 \mathrm{~h} / \text { semana ou } \\
\text { equivalente }\end{array}$ & 3 & 60,0 & 2 & 40,0 & 5 & 100 \\
\hline Outro & 21 & 87,5 & 3 & 12,5 & 24 & 100 \\
\hline TOTAL & 225 & 94,9 & 12 & 5,1 & 237 & 100 \\
\hline
\end{tabular}


Nesse aspecto, LACHER e col. (2000), estudando comunidade de médicos dos Estados Unidos, relacionaram, mais do que com a faixa etária, o uso da internet ao vínculo que os médicos possuíam com instituições acadêmicas. Verifica-se na Tabela 22 que, entre aqueles com menos de 10\% de dedicação às atividades de pesquisa, houve maior percentual de não uso da internet $(16,7 \%)$.

TABELA 22 - Distribuição do tempo de trabalho do docente dos programas de pós-graduação na área de saúde pública, Brasil (2002), de acordo com o uso da internet em suas atividades de pesquisa científica e ensino acadêmico.

\begin{tabular}{|c|c|c|c|c|c|c|c|}
\hline Atividade & Tempo de dedicação & & & Inte & & & \\
\hline \multirow{6}{*}{ Pesquisa } & & \multicolumn{2}{|c|}{ Usa } & \multicolumn{2}{|c|}{ Não usa } & \multicolumn{2}{|c|}{ Total } \\
\hline & & $\mathrm{N}$ & $\%$ & $\mathrm{~N}$ & $\%$ & $\mathrm{~N}$ & $\%$ \\
\hline & $<$ de $10 \%$ & 20 & 83,3 & 4 & 16,7 & 24 & 100 \\
\hline & De $10 \%$ a $40 \%$ & 114 & 95,0 & 6 & 5,0 & 120 & 100 \\
\hline & Mais de $40 \%$ & 91 & 97,8 & 2 & 2,2 & 93 & 100 \\
\hline & & & & & & & $P=0,015$ \\
\hline \multirow[t]{4}{*}{ Ensino } & Não atua & 11 & 78,6 & 3 & 21,4 & 14 & 100 \\
\hline & Até $50 \%$ & 203 & 96,7 & 7 & 3,3 & 210 & 100 \\
\hline & Mais de $50 \%$ & 11 & 84,6 & 2 & 15,4 & 13 & 100 \\
\hline & & & & & & & $P=0,002$ \\
\hline Total & & 225 & 94,9 & 12 & 5,1 & 237 & 100 \\
\hline
\end{tabular}


Pode-se afirmar que a internet é mais utilizada pelos docentes mais envolvidos com as atividades de pesquisa do que por aqueles com maior dedicação ao ensino.

Também se verificou que o uso da internet independe da maneira como o docente respondeu o questionário, forma eletrônica ou impressa, ou seja, não houve associação significativa entre a escolha do impresso e o uso da internet $(p=0,543)$.

\subsection{A internet e a comunicação entre os docentes}

As influências mais positivas da internet na comunicação informal recaíram no contato com colegas, inclusive de outros países. Essa é uma tendência quase unânime entre toda a classe acadêmica. Sem dúvida, por esse processo várias atividades de pesquisa podem se tornar mais ágeis. Podem-se trocar minutas e observações de projetos, manuscritos para publicação, por exemplo, tanto pelo correio eletrônico quanto por meio de chats e listas de discussão.

No caso da comunidade estudada, verificou-se que a comunicação entre os docentes foi fortemente influenciada pela inserção das tecnologias de informação na vida acadêmica. Pela Tabela 23, observa-se que houve melhoria nos contatos entre colegas da própria instituição (73\%), de outras instituições brasileiras $(90,5 \%)$ e também de outros países $(82,2 \%)$. Pode-se afirmar que um dos grandes responsáveis pela melhoria na comunicação entre os pesquisadores tem sido o correio eletrônico, utilizado diariamente por $92,1 \%$ dos docentes estudados. Esse fato pode ser exemplificado com o seguinte comentário livre deixado por um dos docentes estudados: 
“O mais importante para mim na utilização da internet é o correio eletrônico (email) para comunicação com colegas, participação em redes de discussão, troca de informações, acompanhamento de pesquisas, de trabalho de alunos etc.".

Tabela 23 - Número e porcentagem de docentes dos programas de pós-graduação da área de saúde pública, no Brasil (2002), segundo sua opinião sobre a influência da internet em suas atividades de comunicação científica com o uso da internet.

\begin{tabular}{|c|c|c|c|c|c|c|c|c|}
\hline \multirow{3}{*}{$\begin{array}{c}\text { Atividades de comunicação } \\
\text { científica }\end{array}$} & \multicolumn{6}{|c|}{ Opinião sobre a influência da internet } & \multirow{2}{*}{\multicolumn{2}{|c|}{$\begin{array}{l}\text { Não usa } \\
\text { internet nessa } \\
\text { atividade }\end{array}$}} \\
\hline & \multicolumn{2}{|c|}{ Melhorou } & \multicolumn{2}{|c|}{ Piorou } & \multicolumn{2}{|c|}{ Não alterou } & & \\
\hline & N. ${ }^{\circ}$ & $\%^{*}$ & N. ${ }^{\circ}$ & $\% *$ & $\mathrm{~N} .^{\circ}$ & $\% *$ & N. ${ }^{\circ}$ & $\% *$ \\
\hline $\begin{array}{l}\text { Contatos com colegas da sua } \\
\text { instituição }\end{array}$ & 174 & 77,3 & 8 & 3,6 & 36 & 16,0 & 3 & 1,3 \\
\hline $\begin{array}{l}\text { Contatos com colegas de } \\
\text { outras instituições no Brasil }\end{array}$ & 213 & 94,7 & 1 & 0,4 & 8 & 3,6 & - & - \\
\hline $\begin{array}{l}\text { Contatos com colegas de } \\
\text { outros países }\end{array}$ & 193 & 85,8 & - & - & 15 & 6,7 & 10 & 4,4 \\
\hline $\begin{array}{l}\text { Contatos com editores } \\
\text { científicos }\end{array}$ & 141 & 62,7 & 1 & 0,4 & 60 & 26,7 & 16 & 7,1 \\
\hline $\begin{array}{l}\text { Contatos com órgãos de } \\
\text { fomento }\end{array}$ & 167 & 74,2 & 5 & 2,2 & 39 & 17,3 & 7 & 3,0 \\
\hline $\begin{array}{l}\text { Troca de idéias com grupos } \\
\text { de pesquisa }\end{array}$ & 114 & 50,7 & 1 & 0,4 & 62 & 27,6 & 37 & 16,4 \\
\hline
\end{tabular}

*porcentagem calculada em relação aos 225 docentes que usam a internet

Vários são os artigos e teses, nacionais e internacionais, sobre a comunicação entre os pesquisadores e as comunidades acadêmicas via redes eletrônicas que confirmam o correio eletrônico como o serviço mais utilizado da internet (ANDRADE e 
col. 2003, CASTELLANI 1998, FERREIRA 1995, LAZINGER e col. 1997, SILVA 1997, SOUZA 2003, STUDT 1998, 2000, entre outros), por permitir, de maneira simples, a troca de informações. Em 1997, outros estudos no Brasil revelaram que a maior parte $(98,5 \%)$ de outras comunidades acadêmicas já utilizava o correio eletrônico (SILVA 1997). O mesmo ocorria nas empresas brasileiras: CASTILHO FILHO verificou que 82\% delas já utilizavam correio eletrônico, com média de pelo menos uma hora diária.

Destaca-se que 3,6\% dos docentes estudados na presente pesquisa acreditam que a comunicação com colegas da instituição piorou com a internet, fato que deve ser investigado para identificar os fatores que podem influenciar essa opinião. A seguir, comentário de um deles: "...acho que a internet trouxe muito isolamento para os pesquisadores (...) discussões orais, ouvir uma palestra são enriquecedores (...) jogar um pouco de 'prosa fora'; o que não se faz na internet é muito bom para os processos de reflexão".

Demais aspectos relativos à comunicação científica apontados como sendo beneficiados pela internet - contato com os editores científicos $(62,7 \%)$ e troca de idéias com grupos de pesquisa $(50,7 \%)$ - serão comentados na parte referente à influência da internet nas atividades de pesquisa científica (Tabela 23).

Alguns docentes $(8,9 \%)$ consideraram que a internet influenciou positivamente também em outros aspectos, conforme relatos: melhorou orientação de alunos; contatos com a família, amigos e alunos; contatos com fornecedores de materiais; moderador de lista de discussão; com áreas administrativas na própria organização; realização de pesquisa; organização de eventos científicos; realização de artigos 
científicos com pares; projetos multicêntricos e colaborativos; necessidade de comunicação; documentação das instituições.

Esses achados sustentam que sistemas informais de comunicação científica, com o advento da internet, ganharam novas dimensões, possibilitando aos pesquisadores contatos de forma mais ágil e, principalmente, desvinculados de padrões hierárquicos (FERREIRA 1995), reunindo indivíduos separados geograficamente, mantendo a existência dos chamados "colégios invisíveis eletrônicos" (HURD 2000).

\subsection{Divulgação no processo da comunicação científica com a} internet

Outro aspecto inerente ao processo da comunicação científica é a publicação dos resultados de pesquisas nos meios formais de divulgação. No caso da comunidade de docentes estudada, a divulgação dos resultados de pesquisa se dá, principalmente, em veículos impressos, em artigos de periódicos de circulação nacional (93,8\%) e internacional (63,6\%). Publicam também capítulos de livros $(65,8 \%)$ e livros $(36,0 \%)$. Conforme apresentado na Tabela 24, a produção bibliográfica em saúde pública tende a ser mais divulgada nos meios informais de publicação, especificamente pela apresentação de resumos $(70,7 \%)$ e trabalhos completos em congressos $(54,2 \%)$, do que em artigos de periódicos, por exemplo. 
Nota-se baixo índice de publicações eletrônicas para a divulgação de trabalhos. Observa-se que as comunicações em congressos, principalmente resumos $(12,9 \%)$ e trabalhos completos em anais de congressos $(11,6 \%)$, são os veículos mais utilizados na forma eletrônica (Tabela 24). Nesse caso, a própria orientação dos congressos deve estar dirigindo essa escolha, já que atualmente tais eventos estão cada vez mais informatizados, além de essa opção de edição eletrônica propiciar agilidade em sua produção e divulgação e baixo investimento financeiro.

Tabela 24 - Formas de divulgação dos trabalhos produzidos pelos docentes dos programas de pós-graduação em saúde pública (2002) nos últimos três anos.

\begin{tabular}{lcccc}
\hline \multirow{2}{*}{ Formas de divulgação } & \multicolumn{2}{c}{ Impresso } & \multicolumn{2}{c}{ Eletrônico } \\
\cline { 2 - 5 } & N. ${ }^{\circ}$ & $\%^{*}$ & N. $^{\circ}$ & $\%^{*}$ \\
\hline Artigo em periódico de circulação nacional & 211 & 93,8 & 9 & 4,0 \\
Artigo em periódico de circulação internacional & 143 & 63,6 & 7 & 3,1 \\
Capítulo de livro & 148 & 65,8 & 5 & 2,2 \\
Livro & 81 & 36,0 & 5 & 2,2 \\
Trabalho completo em anais de congressos & 122 & 54,2 & 26 & 11,6 \\
Resumos em anais de congressos & 159 & 70,7 & 29 & 12,9 \\
Outra & 6 & 2,7 & 3 & 1,3 \\
\hline
\end{tabular}

*porcentagem calculada em relação aos 225 docentes que usam a internet

No que tange a artigos em periódicos eletrônicos, esse resultado era esperado, pois a oferta de periódicos exclusivamente eletrônicos ainda é muito baixa em comparação com os impressos. 
O formato impresso para a divulgação dos achados científicos tem sido preferido pelo pesquisador, pois, além de ser um meio seguro, garante-lhe propriedade científica e possibilita reconhecimento pelos pares (POBLACION e DUARTE 1989). Essa tendência permanecia, ainda na década de 90, apontada por VOORBIJ (1999), cujo trabalho constatou que os periódicos impressos ainda eram considerados o meio mais importante de comunicação científica, sendo que os acadêmicos julgavam os textos na web uma facilidade extra que não substituiria a informação impressa. Em 2002, MELGOZA e col., investigando necessidades de informação de uma comunidade acadêmica do campo das ciências políticas e econômicas, encontraram que 60\% preferiam a forma impressa de publicações, para livros e artigos.

No entanto, com as facilidades que a internet propicia para os autores e editores científicos, tanto na produção de textos quanto na disponibilização imediata da informação, pode-se atribuir a baixa popularidade dos periódicos eletrônicos aos poucos títulos de interesse disponíveis no mercado.

Assim, publicar no formato exclusivamente eletrônico ainda é atividade pouco realizada no meio acadêmico-científico, nacional e internacional, comparado ao impresso. Pode-se sugerir que publicar em periódico eletrônico depende mais das revistas de interesse para a saúde pública estarem na internet do que propriamente da escolha do pesquisador.

Pode-se dizer que, para a divulgação científica, os recursos eletrônicos não substituem os canais impressos, que ainda persistirão. Porém, as formas eletrônicas de divulgação de resultados de pesquisa tendem a ter seu espaço garantido no futuro, 
pois a comunicação científica eletrônica atende a uma demanda inerente à ciência moderna, ou seja, informação atualizada rápida e acurada.

\subsection{A web e a busca e obtenção da informação}

A web é uma das influências mais marcantes no processo da comunicação científica que, aliada ao correio eletrônico, praticamente representa todo o uso da internet nas comunidades acadêmico-científicas.

Na busca da informação científica via web, destaca-se o importante papel das bibliotecas acadêmicas que, desde o advento das novas tecnologias da informação, mudam seus paradigmas quanto aos processos de tratamento da informação e conseguem disponibilizar informações via bases de dados, serviços on-line e bibliotecas virtuais.

Dessa forma, uma das pretensões do presente trabalho era conhecer a opinião da comunidade de docentes na área de saúde pública sobre a influência da internet em suas atividades de busca e obtenção de informação, vinculadas ao uso de bibliotecas especializadas. Conforme demonstrado anteriormente, a web é o segundo recurso mais utilizado pela comunidade acadêmica estudada $(91,1 \%)$, com mais da metade $(55,6 \%)$ dos docentes fazendo uso diário desse recurso da internet (Tabela 22). Outros trabalhos refletem dados semelhantes, como os de APPLEBEE (1997, 2000), JORDAAN e JONES (1999), LUBANSKI e MATTHEW (1998), entre outros, nos quais a web aparece em segundo lugar de uso por comunidades acadêmicas de outros países. 
Observa-se, na Tabela 25, que todas as atividades elencadas de busca e obtenção de informação foram beneficiadas com o uso da internet, sendo a mais influenciada a realização de levantamentos bibliográficos $(88,9 \%)$ e a menos, a solicitação de serviços de bibliotecas $(54,7 \%)$. Observa-se também que, dentre as demais atividades realizadas pela web, também foram influenciadas a leitura de publicações recentes $(88,0 \%)$, a obtenção de documentos com textos completos (84,9\%) e a consulta aos catálogos de bibliotecas $(75,1 \%)$.

Tabela 25 - Número e porcentagem de docentes dos programas de pós-graduação da área de saúde pública, no Brasil, 2002, segundo sua opinião sobre a influência da internet na forma de busca e obtenção da informação.

\begin{tabular}{|c|c|c|c|c|c|c|c|c|}
\hline \multirow{3}{*}{$\begin{array}{l}\text { Forma de busca da } \\
\text { informação }\end{array}$} & \multicolumn{6}{|c|}{ Opinião sobre a influência da internet } & \multirow{2}{*}{\multicolumn{2}{|c|}{$\begin{array}{l}\text { Não usa internet } \\
\text { nessa atividade }\end{array}$}} \\
\hline & \multicolumn{2}{|c|}{ Melhorou } & \multicolumn{2}{|c|}{ Piorou } & \multicolumn{2}{|c|}{ Não alterou } & & \\
\hline & N. ${ }^{\circ}$ & $\% *$ & N. ${ }^{\circ}$ & $\% *$ & N. ${ }^{\circ}$ & $\%^{*}$ & N. ${ }^{\circ}$ & $\%^{*}$ \\
\hline $\begin{array}{l}\text { Busca em citações em } \\
\text { artigos/livros }\end{array}$ & 189 & 84,0 & - & - & 20 & 8,9 & 12 & 5,3 \\
\hline $\begin{array}{l}\text { Leitura de publicações } \\
\text { recentes }\end{array}$ & 198 & 88,0 & - & - & 17 & 7,6 & 6 & 2,7 \\
\hline $\begin{array}{l}\text { Obtenção de referências com } \\
\text { colegas }\end{array}$ & 180 & 80,0 & 1 & 0,4 & 31 & 13,8 & 7 & 3,1 \\
\hline $\begin{array}{l}\text { Obtenção de material inédito } \\
\text { com colegas }\end{array}$ & 163 & 72,4 & 1 & 0,4 & 36 & 16,0 & 13 & 5,8 \\
\hline $\begin{array}{l}\text { Realização de levantamentos } \\
\text { bibliográficos }\end{array}$ & 200 & 88,9 & 1 & 0,4 & 11 & 4,9 & 9 & 4,0 \\
\hline $\begin{array}{l}\text { Obtenção de } \\
\text { documentos/artigos com } \\
\text { textos completos }\end{array}$ & 191 & 84,9 & 1 & 0,4 & 22 & 9,8 & 6 & 2,7 \\
\hline $\begin{array}{l}\text { Consulta a catálogos de } \\
\text { bibliotecas }\end{array}$ & 169 & 75,1 & 1 & 0,4 & 32 & 14,2 & 16 & 7,1 \\
\hline $\begin{array}{l}\text { Solicitação de serviços da } \\
\text { biblioteca }\end{array}$ & 123 & 54,7 & - & - & 62 & 28,2 & 30 & 13,3 \\
\hline
\end{tabular}

*porcentagem calculada em relação aos 225 docentes que usam a internet 
Esses achados podem indicar que a internet trouxe ao docente certa autonomia na busca da informação desejada, sem necessitar de consulta aos serviços de biblioteca. Ou, também, pode indicar que as bibliotecas estejam sendo bem-sucedidas ao disponibilizar em seus sites fontes de informações com textos completos, por meio de bibliotecas virtuais e serviços remotos, que garantem a autonomia do docente para busca e obtenção da informação científica.

A obtenção de textos integrais na web é uma das grandes metas dos serviços oferecidos à comunidade acadêmica pelas instituições de ensino e pesquisa. Várias iniciativas brasileiras têm permitido que a comunidade acadêmica tenha acesso aos textos integrais na web, aumentando o número de usuários da internet. Inclusive, a área de saúde pública conta com veículo específico que é a SciELO Saúde Pública, com periódicos da América Latina e Espanha.

A comunidade acadêmico-científica brasileira também pode contar com serviços que disponibilizam textos completos, como ocorre com o Portal Brasileiro da Informação Científica da CAPES (http://www.periodicos.capes.gov.br), o Portal do Conhecimento da Universidade de São Paulo (http://www.saber.usp.br), o Portal CRUESP das universidades paulistas USP, UNESP e UNICAMP (http://www.cruesp.bc.unicamp.br), além do da Biblioteca Nacional, com o Programa Biblioteca Nacional Sem Fronteiras (http://www.bn.br/bibsemfronteiras), que são exemplos de obtenção da informação via web, com atuação marcante principalmente de bibliotecas universitárias. Além desses serviços, a comunidade da área da saúde pública pode contar também com as bibliotecas virtuais especializadas e desenvolvidas em parceria com várias instituições da área. 
Outros trabalhos comentam a maior facilidade no acesso e na obtenção da informação científica com o advento da web. LUBANSKI e MATTHEW (1998), em pesquisa no Reino Unido e América do Norte, argumentaram que o maior benefício da internet, apontado por pesquisadores jovens ou idosos, com ou sem habilidade no uso de computadores, foi a facilidade de localização de resultados de pesquisas e acesso a seus dados. Os pesquisadores afirmam que $75 \%$ das atividades de pesquisa daquela comunidade têm sido afetadas significativamente pela internet. No Brasil, CASTELLANI (1998) argumenta que a rede eletrônica propicia acesso a maior volume de informações, gerando aumento na eficiência da pesquisa e conseqüente expansão no volume de trabalhos publicados.

Diante desses relatos, pode-se afirmar que as bibliotecas e os sistemas de informação continuam tendo papel fundamental no processo de comunicação científica na era da virtualidade das informações. As bibliotecas precisam estar adequadas às necessidades de informação de seus usuários para continuar participando do processo de comunicação científica, sendo sua evolução para o mundo virtual fato atrelado à própria evolução da internet (ARAUJO 1999/2000).

No entanto, nota-se que parte das comunidades acadêmicas ainda desconhece o potencial das bibliotecas para auxiliá-la no uso dos recursos eletrônicos. No presente estudo, observou-se que $41,5 \%$ dos docentes não utilizam a internet para solicitação de serviço de bibliotecas ou consideram que ela não alterou essa atividade. Fato semelhante ocorre com a consulta aos catálogos de bibliotecas (21,3\%) (Tabela 25). Resultados similares foram encontrados por APPLEBEE e col., 1997, em pesquisa com comunidade acadêmica da Austrália, onde a maioria não usava a internet para 
contatos com a biblioteca; apenas $2 \%$ o faziam, e $82 \%$ nunca haviam usado a internet para solicitar serviço ou pedir artigos para suas bibliotecas.

Nota-se a falta de divulgação pelas bibliotecas das facilidades de busca e obtenção de informação que a internet propiciou a seus serviços, problema que ocorre nas bibliotecas de todo o mundo. Nesse sentido, WEINGART e ANDERSON (2000), em pesquisa nos Estados Unidos sobre o uso dos recursos de bibliotecas via internet, afirmam que as bibliotecas universitárias precisam investir fortemente na publicidade dos recursos eletrônicos que disponibilizam. ASH (1999) também recomendou que as bibliotecas invistam mais em sua promoção, investigando os fatores que afetam o processo de busca em bases de dados. O autor verificou que a maior dificuldade da comunidade acadêmica é o desconhecimento dos recursos eletrônicos que as bibliotecas oferecem.

Nesse sentido, BRUCE (1999), estudando a percepção do acadêmico sobre a busca da informação via internet, afirmou que há tendência de maior ou menor resistência ou familiaridade e níveis de satisfação de acordo com o sucesso (ou fracasso) que o acadêmico obteve com as bibliotecas de suas instituições. Ou seja, quem utiliza com sucesso bibliotecas tradicionais tende a ter sucesso também com os recursos informatizados para a busca da informação. Portanto, as bibliotecas devem se valer do papel de facilitadora da busca de informação e de selecionadoras da informação especializada que conquistaram com as formas tradicionais, para atrair o pesquisador ao convívio com as novas fontes virtuais. 


\subsection{Influência da internet nas atividades da pesquisa científica}

A maioria das atividades de pesquisa foi beneficiada com o uso da internet, exceto a atividade de processamento e tabulação de dados, a qual não é realizada por meio da rede por $16,4 \%$ dos docentes e é considerada sem alteração por $38,2 \%$ deles (Tabela 26).

Tabela 26- Número e porcentagem de docentes dos programas de pós-graduação da área de saúde pública, no Brasil, 2002, segundo sua opinião sobre a influência da internet em suas atividades de pesquisa científica.

\begin{tabular}{|c|c|c|c|c|c|c|c|c|}
\hline \multirow{3}{*}{ Atividades de pesquisa } & \multicolumn{6}{|c|}{ Opinião sobre a influência da internet } & \multirow{2}{*}{\multicolumn{2}{|c|}{$\begin{array}{l}\text { Não usa } \\
\text { internet nessa } \\
\text { atividade }\end{array}$}} \\
\hline & \multicolumn{2}{|c|}{ Melhorou } & \multicolumn{2}{|c|}{ Piorou } & \multicolumn{2}{|c|}{ Não alterou } & & \\
\hline & $\mathrm{N}$ & $\% *$ & $\mathrm{~N}$ & $\% *$ & $\mathrm{~N}$ & $\% *$ & $\mathrm{~N}$ & $\% *$ \\
\hline $\begin{array}{l}\text { Busca de informação } \\
\text { bibliográfica }\end{array}$ & 208 & 92,4 & - & - & 7 & 3,1 & 6 & 2,7 \\
\hline $\begin{array}{l}\text { Coleta de dados para a } \\
\text { pesquisa }\end{array}$ & 145 & 64,4 & 1 & 0,4 & 53 & 23,6 & 18 & 8,0 \\
\hline $\begin{array}{l}\text { Processamento / tabulação de } \\
\text { dados }\end{array}$ & 88 & 39,1 & - & - & 86 & 38,2 & 37 & 16,4 \\
\hline $\begin{array}{l}\text { Submissão de originais para } \\
\text { publicação }\end{array}$ & 135 & 60,0 & - & - & 65 & 28,9 & 18 & 8,0 \\
\hline $\begin{array}{l}\text { Condução de pesquisas em } \\
\text { colaboração }\end{array}$ & 166 & 73,8 & - & - & 34 & 15,1 & 12 & 5,3 \\
\hline $\begin{array}{l}\text { Emissão de pareceres técnico- } \\
\text { científicos }\end{array}$ & 159 & 70,7 & 4 & 1,8 & 40 & 17,8 & 12 & 5,3 \\
\hline $\begin{array}{l}\text { Desenvolvimento de projetos } \\
\text { de pesquisa }\end{array}$ & 152 & 67,6 & - & - & 49 & 21,8 & 15 & 6,7 \\
\hline $\begin{array}{l}\text { Acompanhamento de projetos } \\
\text { de pesquisa dos orientandos }\end{array}$ & 173 & 76,9 & - & & 34 & 15,1 & 4 & 1,8 \\
\hline Atividades administrativas & 145 & 64,4 & 2 & 0,8 & 46 & 20,4 & 17 & 7,6 \\
\hline
\end{tabular}


Outra atividade menos realizada via internet foi a submissão de originais para publicação $(28,9 \%)$, tendo como causas possíveis o fato de haver poucos títulos de periódicos científicos eletrônicos no meio e de não existir a disposição de gerenciamento eletrônico para o processo de seleção e edição de artigos pela maioria dos periódicos nacionais. No entanto, deve-se destacar que a comunidade estudada considera que a internet tem trazido muitas facilidades, principalmente na comunicação entre os autores e os editores científicos (62,7\% - Tabela 23). Nesse sentido, foram beneficiadas pela internet as atividades de envio de manuscritos para publicação $(60,0 \%)$ e a emissão de pareceres técnico-científicos $(70,7 \%)$ (Tabela 26$)$, apontando para tendência positiva para a inserção das tecnologias de redes na editoria científica.

A coleta de dados para a pesquisa também foi apontada como não alterada com o advento da internet por $23,6 \%$ dos docentes estudados. Nesse sentido, ZHANG (2000), em estudo com acadêmicos americanos da área de humanidades, afirmou que a internet possibilita aos pesquisadores novas oportunidades de uso de instrumentos para coleta de dados para pesquisa, sendo que se podem alcançar cerca de $80 \%$ de respostas a esses instrumentos via internet. Comentário feito por docente na presente pesquisa sugere tendência positiva para o uso da internet na atividade de coleta de dados para pesquisa:

“(...) usos da internet na pesquisa têm sido fundamentais (...) uso de páginas institucionais como fonte para análise de dados (...) utilização de entrevista por meio eletrônico em pesquisas, que permite alcançar pessoas que jamais poderíamos encontrar (...) minha experiência com ambos os procedimentos tem sido muito positiva, mesmo exigindo cuidados metodológicos." 
Nas demais atividades de pesquisa, obteve-se que a internet influencia positivamente no desenvolvimento de pesquisas $(67,6 \%)$, principalmente na condução de pesquisas em colaboração $(73,8 \%)$, incluindo o acompanhamento de projetos dos orientandos (76,9\%). Esses achados corroboram estudo de LUBANSKI e MATTHEW (1998), no qual afirmam que os padrões de trabalho acadêmico têm sido alterados com a internet, principalmente quanto à colaboração no desenvolvimento de pesquisas.

Nesse sentido, BUDD e CONNAWAY, 1997, em estudo sobre hábitos e atitudes de acadêmicos de universidades dos Estados Unidos, afirmam que os acadêmicos passaram a elaborar mais artigos em colaboração devido à disponibilidade e ao uso da internet. Quase a metade $(46,9 \%)$ dessa comunidade considerou haver aumento de trabalhos em colaboração, sendo a expansão geográfica de suas comunidades e participação interdisciplinar as grandes alterações conseqüentes à internet (60\%).

Demais autores também atribuem às facilidades de comunicação e à especialização do conhecimento, a formação de grupos cada vez mais multidisciplinares que estão substituindo o pesquisador solitário do passado (CUNHA 2000, MEADOWS 1999). O comentário seguinte, deixado por um dos docentes contatados na presente pesquisa, ilustra que a internet pode benefiar as atividades de pesquisa:

"Uso diariamente o e-mail, porque coordeno uma pesquisa multicêntrica em quatro países (total de 11 centros) através basicamente do e-mail (administração e recebimento de arquivos). Faço muitos contatos com fabricantes de equipamentos, pesquisadores de outros países e uso muito o 
Medline. Sem a internet suponho que o tempo despendido para qualquer tarefa/resultado seria pelo menos três vezes maior."

Portanto, pode-se afirmar, a partir da presente pesquisa, que um dos grandes benefícios da internet para a pesquisa científica foi a facilidade de comunicação entre os pesquisadores, que propiciou melhoria na condução de pesquisa em colaboração.

Do total da comunidade estudada, apenas $21,4 \%$ declararam divulgar seus resultados de pesquisa em sites próprios. Esse aspecto pode se relacionar a questões de infra-estrutura de equipamentos e recursos humanos das instituições com os quais os docentes possam contar para essa atividade, além da pouca experiência que devem ter para lidar com as linguagens e as estruturas dos websites.

\subsection{Influência da internet nas atividades de ensino acadêmico}

Da mesma forma que ocorreu com as atividades relativas à pesquisa científica, todas as atividades de ensino relacionadas, excluindo a de avaliação de alunos, foram consideradas favorecidas pelo uso da internet (Tabela 27). Os docentes estudados da área de saúde pública brasileira enfatizaram a influência que a internet exerce nas atividades de ensino, principalmente na indicação de fontes de informação aos alunos (85,3\%). O uso da internet para a busca de informações para preparar aulas foi considerado um dos grandes benefícios para a pesquisa $(92,4 \%$ - Tabela 26$)$ e para o ensino (84,0\% - Tabela 27). 
Tabela 27 - Número de docentes dos programas de pós-graduação da área de saúde pública, no Brasil, 2002, segundo sua opinião sobre a influência da internet em suas atividades de ensino acadêmico.

\begin{tabular}{|c|c|c|c|c|c|c|c|c|}
\hline \multirow{3}{*}{ Atividades de ensino } & \multicolumn{6}{|c|}{ Opinião sobre a influência da internet } & \multirow{2}{*}{\multicolumn{2}{|c|}{$\begin{array}{l}\text { Não utiliza } \\
\text { internet } \\
\text { nessas } \\
\text { atividades }\end{array}$}} \\
\hline & \multicolumn{2}{|c|}{ Melhorou } & \multicolumn{2}{|c|}{ Piorou } & \multicolumn{2}{|c|}{ Não alterou } & & \\
\hline & No. & $\% *$ & No. & $\% *$ & No. & $\% *$ & No. & $\% *$ \\
\hline $\begin{array}{l}\text { Busca de informação para } \\
\text { preparar ou ministrar aulas }\end{array}$ & 189 & 84,0 & - & - & 20 & 8,9 & 8 & 3,5 \\
\hline $\begin{array}{l}\text { Indicação de fontes de } \\
\text { informação aos alunos }\end{array}$ & 192 & 85,3 & 1 & 0,4 & 17 & 7,6 & 6 & 2,7 \\
\hline $\begin{array}{l}\text { Disponibilização de textos } \\
\text { didáticos aos alunos }\end{array}$ & 148 & 65,8 & - & - & 52 & 23,1 & 15 & 6,7 \\
\hline $\begin{array}{l}\text { Comunicação com os } \\
\text { alunos }\end{array}$ & 158 & 70,2 & 2 & 0,9 & 47 & 20,9 & 7 & 3,1 \\
\hline $\begin{array}{l}\text { Atualização do conteúdo } \\
\text { de disciplinas }\end{array}$ & 155 & 68,9 & - & - & 45 & 20,0 & 10 & 4,4 \\
\hline Avaliação dos alunos & 77 & 34,2 & 4 & 1,7 & 97 & 43,1 & 32 & 14,2 \\
\hline $\begin{array}{l}\text { Atividades administrativas } \\
\text { referentes ao ensino }\end{array}$ & 126 & 56,0 & 2 & 0,9 & 64 & 28,4 & 20 & 8,9 \\
\hline
\end{tabular}

* porcentagem calculada em relação aos 225 docentes que usam a internet

Outras atividades, como as direcionadas à orientação de alunos, também tiveram grandes benefícios com a internet. Citam-se a comunicação com os alunos (70,2\%) e a disponibilização de textos (65,8\%).

A maioria dos docentes estudados (74,3\%) não atua com a tecnologia do ensino à distância e nem disponibiliza via web informações sobre suas disciplinas $(76,4 \%)$.

$\mathrm{Na}$ literatura publicada, poucos autores abordam aspectos referentes à influência da internet no ensino acadêmico no âmbito das instituições universitárias, 
especificamente no ensino de pós-graduação, que possam subsidiar os dados desta pesquisa. Um deles, o de COFFIN e MacINTYRE no Canadá, em 1999, sobre o ensino de pós-graduação, discorre sobre as barreiras que dificultam a assimilação do uso de computadores, comprovando que há forte relação entre experiência prévia com computadores e eficácia na aprendizagem, sendo fatores negativos para esse objetivo a baixa-estima e os altos níveis de ansiedade combinados com a inexperiência.

No entanto, outros trabalhos confirmam que a internet facilita as atividades de ensino acadêmico nas universidades, como os de BRUCE 1995, CASTELLANI 1998, FERREIRA 1995, LAZINGER e col. 1997, LIEBSCHER e col. 1997, SILVA 1997, STUDT 1998, 2000, entre outros. No entanto, APPLEBEE e col., em 1997, abordam o fato de a internet ainda ser pouco utilizada para distribuição de material didático e para recebimento de tarefas de alunos. No presente trabalho, observou-se que a internet influenciou muito pouco nas avaliações dos alunos (34,2\% -Tabela 27), provavelmente por não se aplicar aos métodos utilizados pelo docentes na avaliação de seus alunos.

Um dos docentes estudados deixou comentário e sugestão sobre a influência da internet no ensino, conforme descrito a seguir:

\section{“(...) Penso que laboratórios de informática amplamente capacitados} deveriam ser instalados nas escolas de graduação de modo a permitir que alunos tenham amplo acesso. É impressionante como alunos se transformam quando percebem as perspectivas possíveis com o computador e a INTERNET. Esperemos que a EAD [Educação à Distância] venha também a se fazer realidade em breve em nossas universidades". 
Alguns docentes registraram que houve melhora em outras atividades não relacionadas, destacando-se os seguintes comentários: "disponibilização de trabalhos dos alunos"; "elaboração de projetos".

\subsection{Barreiras e expectativas de uso da internet}

Várias das atividades acadêmicas relacionadas ao ensino e à pesquisa científica não podem mais ser desenvolvidas adequadamente sem o emprego das tecnologias da informação, principalmente por haver uma quantidade excessiva de informação circulante que não poderia ser processada de outra forma (MEADOWS 1999). Nesse sentido, nota-se que os principais obstáculos para o uso da internet na vida acadêmica relacionam-se a questões de infra-estrutura das instituições, que muitas vezes não conseguem manter redes, capacitação e equipamentos adequados para uso da internet.

Vários trabalhos alertam para a necessidade de fortes investimentos na manutenção de redes e equipamentos, principalmente nas universidades brasileiras em que ocorre o desenvolvimento da pesquisa e da ciência no Brasil. Em um desses trabalhos, MEADOWS (1999) argumenta que as novas tecnologias de informação propiciam a igualdade de acesso à informação científica para os países desenvolvidos e para os em desenvolvimento e que essa condição se manterá se as instituições conseguirem manter recursos para atualização de equipamentos e programas. 
Assim, procurou-se detectar junto aos docentes as dificuldades encontradas para o efetivo uso da rede e quais expectativas em relação à internet no dia-a-dia de sua vida acadêmica.

\section{a) Infra-estrutura das instituições}

Dentre as principais dificuldades elencadas para o uso dos recursos tecnológicos pela comunidade acadêmica estão as relacionadas às de infra-estrutura de rede, de equipamentos e softwares e de apoio técnico oferecidos pelas instituições.

Na tabela 28, verificam-se quais os recursos disponíveis pelas instituições para o uso da internet. Assim, 77,3\% contam com rede local para acesso à internet, 76,4\% com projetor multimídia, 68,9\% com salas de aula com pontos para uso de internet e $63,6 \%$ com bibliotecas com acesso à internet. Mais da metade dos respondentes $(60,9 \%)$ conta com computadores individuais para suas atividades. Vários deles $(39,1 \%)$ não possuem computadores próprios, e outros $(30,2 \%)$ compartilham computadores com colegas. Poucos contam com intranets $(37,3 \%)$ e treinamentos para o uso dessas tecnologias (26,7\%). Comentários como “(..) nossa escola está longe de oferecer o que preciso”, “(...) falta de equipamento próprio” ou “(...) quando consigo projetor e laptop" mostram que nem todas as instituições acadêmicas em saúde pública estão em situação satisfatória quanto à infra-estrutura de redes para seus docentes. 
Tabela 28 - Número e porcentagem de docentes dos programas de pós-graduação da área de saúde pública no Brasil, em 2002, segundo a utilização dos recursos tecnológicos oferecidos a eles pelas respectivas instituições em que atuam.

\begin{tabular}{lcc}
\hline \multicolumn{1}{c}{ Recursos tecnológicos disponíveis } & N de docentes & \%* \\
\hline Rede local com acesso à internet & 174 & 77,3 \\
Projetor multimídia (datashow) & 172 & 76,4 \\
$\begin{array}{l}\text { Sala de aula com pontos de internet para todos (ou } \\
\text { maioria) dos alunos }\end{array}$ & 155 & 68,9 \\
Biblioteca com acesso à internet & 143 & 63,6 \\
Computador individual & 137 & 60,9 \\
Computador portátil (notebook) & 120 & 53,3 \\
Intranet & 84 & 37,3 \\
Computador compartilhado & 68 & 30,2 \\
Treinamentos & 60 & 26,7 \\
Sala de aula com pelo menos um ponto de internet & 48 & 21,3 \\
\hline
\end{tabular}

*porcentagem calculada em relação aos 225 docentes que usam a internet

Embora a maioria dos docentes tenha afirmado possuir acesso à internet, projetores multimídia, salas de aula e bibliotecas com internet (Tabela 28), observa-se que $34,7 \%$ consideraram os equipamentos insuficientes (Tabela 29). Além disso, a lentidão no acesso $(44,4 \%)$ e a desatualização de softwares e equipamentos $(25,3 \%)$ foram considerados fatores que dificultam o uso da internet. 
Tabela 29 - Número e porcentagem de docentes dos programas de pós-graduação da área de saúde pública no Brasil, 2002, segundo motivos por eles considerados como dificuldades para o uso da internet.

\begin{tabular}{lcc}
\hline Dificuldades para o uso da internet & No de docentes $^{*}$ & \%* \\
\hline Lentidão no acesso & 100 & 44,4 \\
Falta de ajuda técnica & 78 & 39,1 \\
Equipamentos insuficientes & 69 & 34,7 \\
Dificuldade em encontrar informações na internet & 57 & 30,7 \\
Equipamentos e softwares desatualizados & 37 & 25,3 \\
Resistência em usar essas tecnologias & 24 & 16,4 \\
Falta de qualidade nos conteúdos da internet & 24 & 10,7 \\
Excesso de informação na internet & 12 & 10,7 \\
Falta de tempo para explorar tudo o que a & & 5,3 \\
internet oferece & 11 & 4,9 \\
\hline Não existência de nenhuma barreira &
\end{tabular}

*porcentagem calculada em relação aos 225 docentes que usam a internet

Vale lembrar que um dos motivos para o não uso da internet, alegado por 16,7\% dos docentes, foi a não existência de equipamentos necessários funcionando em rede (Tabela 17).

Problemas apontados nesta pesquisa com docentes brasileiros foram encontrados em demais estudos (JACOBS 1998, JORDAAN e JONES 1999), como o de APPLEBEE (1997), que considerou como limitação de uso da internet por comunidade acadêmica australiana o fato de a velocidade e a capacidade da rede serem incompatíveis com os computadores utilizados. JACOBS (1998), em universidade americana, também apontou como barreira para o uso da rede a 
inadequação dos computadores quanto à velocidade da rede. Pode-se afirmar que as questões de inadequação da infra-estrutura das instituições são predominantes quando se trata de dificuldades para uso efetivo da internet.

Poucos estudos mostram o custo-benefício do investimento das instituições em tecnologia de informação, como o aprimoramento da infra-estrutura de redes para sua comunidade acadêmica. Essa questão não parece ser objeto de interesse dos estudos realizados em países desenvolvidos que investem fortemente em infra-estrutura de redes. No meio acadêmico brasileiro, o pouco investimento em melhor infra-estrutura de redes, manutenção e atualização de softwares e equipamentos, acesso a bases de dados e portais científicos, que promovem facilidades para o desenvolvimento das atividades acadêmico-científicas de suas comunidades, pode decorrer da falta de recursos financeiros e de política das instituições para esse fim.

\section{b) Treinamentos e ajuda técnica}

Conforme Tabela 28, apenas $26,7 \%$ da comunidade estudada dispõe de treinamentos para o uso da internet. Esta é uma necessidade sentida por outras comunidades, conforme relatos de autores como APPLEBEE e col. (1997), que encontraram grande parte (75\%) da comunidade acadêmica australiana necessitando de treinamento para aprender a usar e conhecer as facilidades da internet. BRUCE (1998) argumenta que, na maioria dos casos, o conhecimento para realizar buscas na internet para solucionar problemas é adquirido com autotreinamento do docente, com significante ajuda de amigos e colegas. JACOBS (1998) afirma ser a falta de conhecimento mais apurado o maior empecilho para melhor proveito da internet pela 
comunidade acadêmica, argumentando ser a autocapacitação a pior forma de adquirir essa habilidade.

Além disso, APPLEBEE (1997) aponta que as constantes e rápidas "novas versões" de softwares são o fatores que geram desatualização dos equipamentos e necessidade de capacitação contínua dos usuários de redes eletrônicas.

Destaca-se que um dos motivos alegados para o não uso da internet foi a falta de conhecimento (Tabela 17): "Ainda não sei navegar na internet" e "Não tenho conhecimento suficiente de informática".

Nesse sentido, cabe destacar o importante papel que as bibliotecas podem desempenhar na capacitação de suas comunidades acadêmicas, como exemplificado na área de saúde pública por CUENCA 1999 e CUENCA e col.1999, mostrando que a comunidade de docentes e pesquisadores pode contar com vários programas de capacitação. Vários docentes iniciaram-se no uso das novas tecnologias participando de treinamentos para acesso a bases de dados. A partir dessa experiência, passaram a conviver com tecnologias de informação introduzidas consecutivamente em sua vida acadêmica. As bibliotecas já estão atentas a essa demanda, oferecendo programas formais de treinamento para manter seu usuário atualizado quanto às novas tecnologias da informação (SAMPAIO e col. 2001).

Além disso, há a questão da ajuda técnica para resolver problemas relativos aos recursos tecnológicos, cuja falta foi apontada por mais de um terço $(39,1 \%)$ dos docentes da área de saúde pública (Tabela 29). Esses dados confirmam a necessidade de haver mais investimentos em recursos humanos e capacitação 
tecnológica das instituições, além de suporte técnico para apoiar o docente no uso dos recursos tecnológicos.

Outros autores também abordam a falta de capacitação e de ajuda técnica para o uso da internet, como o estudo de FIGUEIRA NETTO (1994), argumentando que os pesquisadores brasileiros tendem a utilizar inadequadamente as redes eletrônicas, e o de ITURRI, comentando que a comunidade de pesquisadores brasileiros tende a subutilizar os equipamentos de informática, usando, por exemplo, o computador somente para digitação.

Portanto, apesar dos investimentos das universidades brasileiras em infraestrutura para a inserção das novas tecnologias de comunicação, o presente estudo destaca que sua comunidade acadêmica não está totalmente satisfeita com os recursos tecnológicos disponíveis para suas atividades. A insuficiência apontada por grande parte da comunidade estudada em relação aos equipamentos, à estrutura de redes, ao apoio técnico e aos treinamentos constitui a principal barreira para o uso efetivo da internet.

Nesse sentido, vale destacar as considerações de MEADOWS (1999) sobre o futuro da comunicação científica com as novas tecnologias, afirmando que os países que investirem em infra-estrutura de redes serão privilegiados na divisão entre os pobres e os ricos de informação, o que acarretará o isolamento dos demais. LUBANSKI e MATTHEW (1999) também abordaram o problema da falta de investimentos para uso de redes eletrônicas, atribuindo a melhoria na qualidade da pesquisa ao fato de os melhores pesquisadores estarem em instituições que promovem grandes investimentos em infra-estrutura. 


\section{c) Resistência e motivação}

Vale lembrar que mesmo usando a internet alguns docentes afirmaram ter certa resistência ou aversão ao uso de tecnologias: "Realmente apresento certa resistência ao uso da infomática”; “(...) preciso utilizar mais a internet (...) só não o faço por um pouco de resistência (...)". Alguns autores apresentam relatos sobre a presença de certa resistência em relação à inserção dessas tecnologias em comunidades acadêmicas, porém argumentam que, para a maioria, as novas tecnologias são bemvindas como provedoras de interação nunca imaginadas, abrindo novos horizontes e possibilidades de maior engajamento em pesquisas a um custo menor e em dimensão quase instantânea (COFFIN e MacINTYRE 1999, ITURRI 1998, SAVOLAINEN 2000).

A aversão ao uso de computadores pode se relacionada a questões de caráter particular, como fobia (ITURRI 1998) ou experiências negativas anteriores (COFFIN e MacINTYRE 1999), entre outras. A resistência em utilizar essas tecnologias foi demonstrada por 16,4\% da comunidade de docentes (Tabela 29).

Ressalta-se que aqueles que não usam a internet em suas atividades acadêmicas também atribuem esse fato à falta de adaptação às novas tecnologias (Tabela 17).

ITURRI (1998) aponta outros motivos para a resistência ao uso de computadores: o fato dos pesquisadores brasileiros da área de saúde pública acreditarem que a introdução de novas tecnologias equivale a reduzir pessoal acadêmico ou ao fato dessa comunidade perceber que o aprendizado das novas 
tecnologias exige esforço e tempo desmedidos, em comparação com os objetivos obtidos.

O não uso de computadores também está associado a fator de ordem pessoal, que é a motivação para esse fim. SAVOLAINEN (2000) afirma ser a falta de motivação uma importante barreira quando se trata de iniciação no uso da internet. No presente trabalho, dentre os não-usuários da internet, a falta de motivação se reflete no fato de o docente conseguir o que precisa por meio de colegas ou de colaboradores $(58,3 \%)$, conforme indicado na Tabela 17. Já uma forte motivação positiva para o uso da internet pode ser a necessidade do docente para suas atividades acadêmicas, conforme relato:

\section{“(..) embora tenha tido enorme resistência para entrar nessa} nova tecnologia, fui obrigado a entrar e faço uso dela apenas naquilo que não tenho como 'fugir', e nisso acabo algumas vezes achando muito bom!"

Outro aspecto de caráter particular considerado quanto ao uso da internet, e alegado por alguns docentes da comunidade estudada, foi a falta de tempo para explorar tudo o que a internet oferece (5,3\%) (Tabela 29). APPLEBEE, 1997, também aponta como dificuldade o fato de o docente não ter tempo necessário para usar e explorar todas as possibilidades que a internet oferece, provavelmente pelo fato de o pesquisador, à medida que evolui na carreira, passar a ter mais responsabilidades e atividades mais diversificadas que lhe ocupam demasiadamente o tempo (APPLEBEE 1997, JACOBS 1998, MEADOWS 1999). 
“Sinto que poderia utilizar mais todos os recursos que ela oferece. Só não o faço por um pouco de resistência, um pouco por falta de tempo e também porque não tenho muita paciência."

No entanto, para outros autores ocorre o inverso: afirmam que o uso da internet proporciona-Ihes economia de tempo, fato sinalizado como uma das grandes vantagens desse recurso (FIGUEIRA NETTO 1994).

\section{d) Excesso de informação}

A questão da sobrecarga de informações propiciada pela internet tem sido bastante debatida na literatura (CIANCONI 2001, GAROTTINI 2001, LAWRENCE e GILES1998, 1999, MARCHIORI 2002, POWELL e FOX 1998, REPMAN e CARLON 1999, TARGINO 2000, TERRA e GORDON 2000, VOORBIJ 1998, entre outros) e foi também apontada pelos docentes brasileiros como um empecilho para o melhor uso da internet. A comunidade estudada considerou como barreiras para o uso efetivo da rede o excesso de informações (10,7\%) e a dificuldade em encontrá-las (30,7\%) (Tabela 29).

Desde a década de 80, quando a informática passou a fazer parte do dia-a-dia das comunidades acadêmicas (principalmente nos países desenvolvidos), acreditou-se que ela solucionaria os problemas de armazenamento de grande volume de dados, além de facilitar a busca e a obtenção de informações, bastando algumas gerações de pesquisadores para que se tornasse rotina no meio acadêmico. 
No entanto, o que se tem assistido é a diversidade cada vez mais acentuada da tecnologia da informação disponível para o pesquisador, sem que ele tenha alcançado o total domínio de uso dessas tecnologias. Um dos grandes problemas sentidos é a necessidade de lidar com o excesso de informação propiciado pela internet. Um pesquisador menos familiarizado com as fontes eletrônicas tende a verificar centenas de sites resultantes de uma busca, com a possibilidade de não encontrar nenhuma informação útil para sua pesquisa. Nesse processo, perde-se muito tempo, constituindo estímulo negativo para o uso da internet.

\section{e) Qualidade e credibilidade dos conteúdos da Internet}

A questão da credibilidade das informações também tem sido considerada uma dificuldade para maior utilização da internet. Em relação aos conteúdos da web, diversos autores concordam que a quantidade de links irrelevantes (VOORBIJ 1999, MARCHIORI 2002, CIANCONI 2001) e inativos, conseqüentes à desatualização dos sites (CIANCONI 200), faz com que não se possa garantir a permanência do texto na web (MARCHIORI 2002), afetando a percepção do pesquisador quanto à qualidade desses conteúdos. Nesse sentido, $10,7 \%$ da comunidade de docentes afirmou não considerar de qualidade os conteúdos da internet (Tabela 29).

Também relativo à qualidade dos conteúdos da internet está a questão da dificuldade em encontrar informações úteis, apontada por 30,7\% da comunidade estudada (Tabela 29). Esta constitui obstáculo para maior uso da internet pelo pesquisador e desafio para as bibliotecas com o advento das novas tecnologias. $\mathrm{O}$ 
comentário a seguir de um dos docentes estudados ilustra a necessidade de validação e organização das informações contidas na internet:

"A comunidade científica deveria discutir como poder classificar alguns sites quanto à credibilidade. Como não existe a figura do editor em comunicação científica, qualquer pesquisa ou trabalho com conteúdos e metodologia sofríveis encontram-se na internet. É muito trabalho 'garimpar' o que realmente vale a pena."

Nesse sentido, algumas iniciativas visam a implementar soluções para minimizar os problemas da explosão informacional, da curta permanência dos textos na web e da garantia da qualidade dos conteúdos da internet com as bibliotecas virtuais. No entanto, nessa fase de incertezas, devem permanecer as mesmas regras que garantem a qualidade dos conteúdos impressos: vinculação a instituições com credibilidade no meio acadêmico-científico, revisão pelos pares e validação por meio dos processos de seleção das bibliotecas.

A efemeridade da informação na internet também é discutida na literatura. KOEHLER (1999) afirmou haver alterações diárias na grande maioria (97\%) dos sites. Esse fato é corroborado por MOLINEUX e WILLIAMS (p.325): “(..) algumas fontes citadas nesta pesquisa provavelmente terão desaparecido até o tempo em que ela for publicada, e outras já devem ter desaparecido enquanto este texto esta sendo escrito." Acredita-se que a manutenção dos textos na internet permanecerá como um dos grandes desafios a ser resolvidos. 


\subsection{Opiniões conclusivas dos docentes sobre a internet}

No questionário também foi destinado um espaço no qual o docente pudesse deixar opiniões a respeito dos pontos abordados no presente estudo. As opiniões obtidas nesse campo, de livre resposta do docente, estão apresentadas na íntegra no ANEXO 7, e algumas outras, relevantes para subsidiar alguns dos achados, distribuídas ao longo do texto.

$\mathrm{Na}$ Tabela 30, citam-se algumas colocações previamente selecionadas do questionário sobre a internet, para conhecer as expectativas dos docentes estudados em relação a seu uso em suas atividades acadêmico-científicas.

A colocação mais assinalada foi: "é mais fácil se comunicar com outros pesquisadores nos dias de hoje com a internet do que antes", com 76,4\% dos docentes concordando totalmente, confirmando que o maior benefício da rede foi, realmente, a comunicação entre os pesquisadores. Vários docentes deixaram opiniões enfatizando esse argumento:

"É uma tecnologia que aumentou expressivamente o acesso e a troca de informação científica, quebrando barreiras e aproximando pesquisadores, docentes e alunos de diferentes lugares."

"A internet pertence aos avanços tecnológicos e acarreta maior impacto na divulgação e intercâmbio entre pesquisadores." 
Tabela 30 - Número e porcentagem de docentes dos programas de pós-graduação da área de saúde pública no Brasil, em 2002, segundo suas opiniões sobre o uso da internet.

\begin{tabular}{|c|c|c|c|c|c|c|c|c|c|c|}
\hline \multirow{2}{*}{ Colocações* } & \multicolumn{2}{|c|}{$\begin{array}{l}\text { Discorda } \\
\text { totalmente }\end{array}$} & \multicolumn{2}{|c|}{$\begin{array}{c}\text { Discorda } \\
\text { parcialmente }\end{array}$} & \multicolumn{2}{|c|}{ Neutro } & \multicolumn{2}{|c|}{$\begin{array}{l}\text { Concorda } \\
\text { parcialmente }\end{array}$} & \multicolumn{2}{|c|}{$\begin{array}{l}\text { Concorda } \\
\text { totalmente }\end{array}$} \\
\hline & N. ${ }^{\circ}$ & $\% *$ & N. ${ }^{\circ}$ & $\% *$ & N. ${ }^{\circ}$ & $\% *$ & N. ${ }^{\circ}$ & $\% *$ & N. ${ }^{\circ}$ & $\%$ \%* \\
\hline $\begin{array}{l}\text { É mais fácil se comunicar com } \\
\text { outros pesquisadores nos dias } \\
\text { de hoje com a internet do que } \\
\text { antes }\end{array}$ & 3 & 1,3 & 4 & 1,8 & 4 & 1,8 & 35 & 15,6 & 172 & 76,4 \\
\hline $\begin{array}{l}\text { Venho usando cada vez mais a } \\
\text { internet no decorrer do tempo }\end{array}$ & 5 & 2,1 & 5 & 2,1 & 9 & 4,0 & 69 & 30,7 & 129 & 57,3 \\
\hline $\begin{array}{l}\text { Sempre encontro alguma } \\
\text { informação importante na } \\
\text { internet }\end{array}$ & 3 & 1,3 & 17 & 7,6 & 14 & 6,2 & 108 & 48,0 & 75 & 33,3 \\
\hline $\begin{array}{l}\text { É fácil ficar atualizado } \\
\text { consultando a internet }\end{array}$ & 8 & 3,6 & 34 & 15,1 & 18 & 8,0 & 96 & 42,7 & 61 & 27,1 \\
\hline $\begin{array}{l}\text { A internet trouxe a } \\
\text { possibilidade de aprender o uso } \\
\text { de tecnologias emergentes } \\
\text { para o ensino/pesquisa }\end{array}$ & 9 & 4,0 & 18 & 8,0 & 40 & 17,8 & 94 & 41,8 & 58 & 25,8 \\
\hline $\begin{array}{l}\text { Tenho consultado menos } \\
\text { publicações impressas desde } \\
\text { que comecei a usar a internet }\end{array}$ & 54 & 24,0 & 31 & 13,8 & 30 & 13,3 & 48 & 21,3 & 54 & 24,0 \\
\hline $\begin{array}{l}\text { A quantidade de publicações } \\
\text { aumentou devido às facilidades } \\
\text { da internet }\end{array}$ & 11 & 4,9 & 25 & 11,1 & 64 & 28,4 & 57 & 25,3 & 53 & 23,6 \\
\hline $\begin{array}{l}\text { A internet se tornou a fonte de } \\
\text { informação mais importante } \\
\text { para minhas atividades }\end{array}$ & 38 & 16,9 & 36 & 16,0 & 27 & 12,0 & 81 & 36,0 & 35 & 15,6 \\
\hline $\begin{array}{l}\text { A qualidade das pesquisas } \\
\text { melhorou com a internet }\end{array}$ & 33 & 14,7 & 32 & 14,2 & 56 & 24,9 & 69 & 30,7 & 26 & 11,6 \\
\hline $\begin{array}{l}\text { Conheço o que a internet } \\
\text { oferece na minha área de } \\
\text { especialização }\end{array}$ & 9 & 4,0 & 23 & 10,2 & 23 & 10,2 & - & - & - & - \\
\hline
\end{tabular}

*relacionadas na ordem de decrescente, de acordo com maior indicação de "concorda totalmente"

**porcentagem calculada em relação aos 225 docentes que usam a internet

Em segundo lugar de aprovação pelo docente estudado ficou a constatação de que a internet é utilizada cada vez mais no decorrer do tempo, por 88,0\%. Dado 
semelhante foi encontrado por LUBANSKI e MATTHEW (1998), trabalho no qual 36\% da comunidade acadêmica usa a internet cada vez mais e $18 \%$, cada vez mais rapidamente. Diante dessa constatação e dos dados encontrados no presente estudo, pode-se afirmar que a internet tem seu espaço garantido na dia-a-dia da vida acadêmica, pois facilita as atividades de ensino e de pesquisa científica.

Grande parte dos docentes (81,3\%) concordou que "sempre encontra alguma informação importante na Internet", embora, destes, 48,0\% tenham concordado apenas parcialmente com essa colocação. Da mesma forma, a colocação "é fácil ficar atualizado consultando a internet", indicada por $69,8 \%$, pode levar à conclusão de que os que encontram informações importantes na internet com maior facilidade são aqueles que conhecem os recursos adequados para a busca e a obtenção da informação de caráter científico, como as bases de dados e os portais de textos completos.

As universidades e instituições de pesquisa foram as primeiras a se beneficiar com a inserção das novas tecnologias de informação em seu cotidiano. Assim, vários docentes tiveram de aprender a conviver com essas tecnologias como condição para a realização de várias de suas atividades acadêmicas. Perguntados se "a internet trouxe a possibilidade de aprender o uso de tecnologias emergentes para o ensino e a pesquisa", $67,6 \%$ tiveram opinião favorável. No entanto, $12,0 \%$ discordaram dessa afirmativa, parecendo confirmar a colocação de ITURRI (1998), que, ao abordar a questão da resistência ao uso de computadores pelos pesquisadores, indicou que o aprendizado de novas tecnologias Ihes exige esforço e tempo desmedidos em comparação com os objetivos obtidos. Portanto, pode-se afirmar que o uso da internet significa aprendizado contínuo por parte do docente, principalmente devido às 
inúmeras versões que são desenvolvidas para um software, que podem levar ao uso de novos equipamentos e que exigem novo aprendizado em curto espaço de tempo.

A questão do uso de publicações impressas e eletrônicas foi a que menos apresentou opinião formada. Na Tabela 30, observa-se que $24,0 \%$ dos docentes concordaram totalmente que "têm consultado menos publicações impressas desde que começaram a usar a internet", sendo que outros $24,0 \%$ discordaram totalmente. No entanto, parece haver tendência positiva quanto ao futuro dos eletrônicos no meio científico, conforme afirmações dos docentes estudados:

“(...) Cada vez mais, periódicos estão disponibilizando versões full-text, e isto é de uma importância extraordinária para a pesquisa e o ensino."

“(..) A internet, a meu ver, não substitui o texto impresso, mas de fato tem representado um imenso avanço na atualização de informações indispensáveis às atividades de ensino, pesquisa, serviço e até mesmo no tocante às atividades administrativas."

Quanto às facilidades da internet propiciarem "aumento de publicações", parece ainda não haver opinião formada do docente estudado. Essa questão foi a que apresentou maior índice de neutralidade (28,4\%). Alguns autores argumentam que a internet acarreta aumento de publicações devido principalmente à informatização nas atividades de pesquisa, que permitem contínuo crescimento da quantidade de informações científicas em circulação (MEADOWS 1999). Porém, ainda não há como afirmar que a produtividade científica aumentou com o advento da internet. $\mathrm{Na}$ literatura sobre o assunto, LUBANSKI e MATTHEW (1998) atribuem à internet apenas o aumento de co-autorias nas publicações científicas. 
A questão sobre a internet ter propiciado melhoria na qualidade das pesquisas teve aprovação de $42,3 \%$ dos docentes estudados, porém mais da metade $(53,8 \%)$ discordou ou não teve opinião a respeito. Alguns comentários refletem preocupação do docente em relação ao que se encontra na internet e ao que a falta de qualidade pode ocasiar à comunidade acadêmica:

“(..) acho que sofremos de 'information overload', isto é, excesso de informação, com ênfase no quantitativo e esquecimento da qualidade, e que a internet está ampliando isto, junto com a tendência de desumanização do nosso trabalho."

“(..) acho que a internet trouxe muito isolamento para os pesquisadores e que vem diminuindo muito a criatividade entre os alunos que têm uma fonte - seja qual for o assunto - inesgotável no computador."

No entanto, LUBANSKI e MATTHEW (1998) argumentam que a internet propiciará grande melhora na pesquisa científica, uma vez que se (...) pode trabalhar com os melhores - não importa onde estejam." Além disso, a literatura aponta que os pesquisadores consideram que o benefício da internet à questão da qualidade está na maior visibilidade que propicia à validação das informações. Os dados na internet tendem a ter mais visibilidade, ou seja, o autor já espera que seu trabalho seja visto e criticado por um número maior de colegas. Seis entre dez pesquisadores afirmaram que suas pesquisas foram beneficiadas, em termos de qualidade, com o uso da internet (LUBANSKI e MATTHEW 1998). 
Interessante ressaltar que a afirmação "conheço o que a internet oferece na minha área de especialização" não teve a aprovação de nenhum docente. Foi a questão que obteve menor número de respostas (24,9\%). Destes, 14,4\% discordaram dessa afirmação. Isto pode ser reflexo da soma de vários fatores, como excesso de informações na internet, velocidade na alteração dos conteúdos da internet e falta de habilidade na busca da informação. Estes podem propiciar insegurança do docente quanto à sua atualização na área de especialização.

O comentário a seguir resume o pensamento de vários docentes da comunidade acadêmica estudada sobre a influência da internet em suas atividades acadêmico-científicas:

"Considero que a internet ampliou, em muito, as facilidades para o melhor desenvolvimento de minhas atividades acadêmico-científicas, pois permitiu maior acesso e agilidade a informações de importância para muitas das minhas atividades."

As considerações apresentadas pela comunidade acadêmica em saúde pública estudada são apresentadas de forma pontual e resumida na FIGURA 1. Por meio de um fluxo, são mostradas as principais influências da internet nas atividades acadêmicocientíficas dessa comunidade nas diversas fases do processo da comunicação científica, desde a busca da informação à divulgação do conhecimento produzido. 
Figura 1 - A internet nas atividades acadêmico-científicas dos docentes da área de saúde pública no Brasil

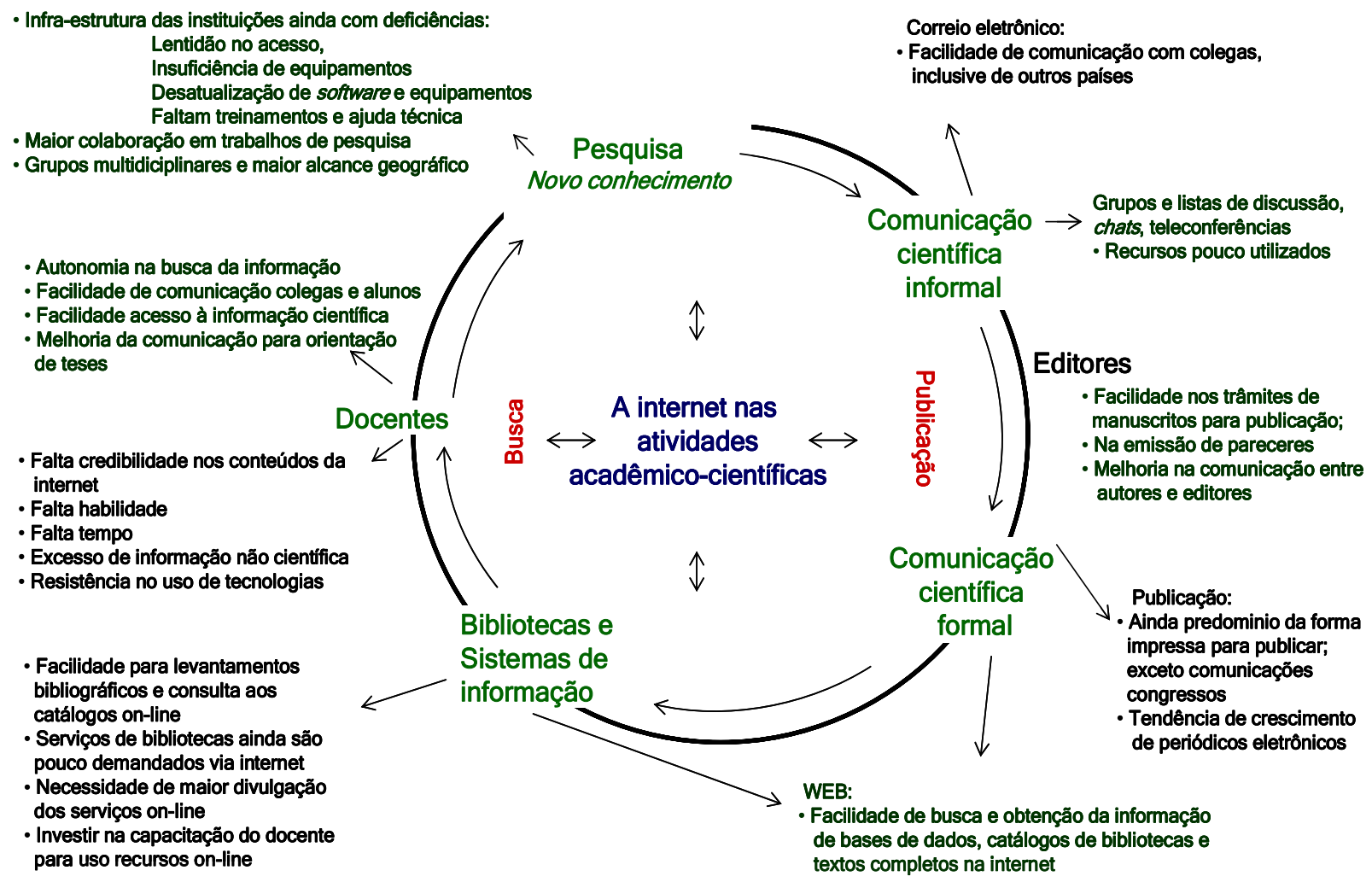

Fluxo adaptado de MARCHIORI (2002)

Como no Brasil a internet foi utilizada mais intensamente nas universidades somente a partir de 1995, não se podem ainda concluir estudos sobre seu impacto, e sim descrever os efeitos produzidos em determinadas atividades acadêmicas. A internet é muito mais do que um ambiente tecnológico de informação. É uma 
tecnologia social, um avançado meio de comunicação, um novo paradigma de publicação, uma opção de lazer e comércio. Gradualmente se transformará em um meio de utilidade pública, que diariamente alterará padrões de conhecimento (BRUCE 1999).

Dada às características sociais e temporais da internet, necessitam-se de vários anos para que se possa obter qualquer avaliação de seu impacto, o que não pode ser possível em tão curto período de tempo de sua introdução na comunidade acadêmicocientífica. Impacto, segundo MENOU (1999), significa "mudança substantiva e duradoura que ocorre na base de padrões - no conhecimento, no comportamento, na organização e na eficácia dos indivíduos, instituições ou sociedade". Este somente pode ser medido a partir de efeitos como adaptação, adoção e institucionalização da internet ao longo do tempo, não sendo obtidos senão depois de vários anos. 


\section{CONCLUSÕES E CONSIDERAÇOES FINAIS}

\section{Uso de questionário eletrônico}

1. O uso de questionário em HTML para ser respondido via internet tende a obter o mesmo sucesso na coleta de dados que o uso da forma impressa, com o benefício da possibilidade de criação de banco de dados, que permite inserção imediata das informações obtidas.

2. A preferência do docente pelo questionário eletrônico tende a predominar sobre o impresso.

\section{Caracterização da população estudada}

3. A maioria dos docentes estudados da área de saúde pública no Brasil encontra-se na faixa etária entre 41 e 60 anos, grande parte trabalhando em regime de tempo integral e dedicando-se exclusivamente às suas atividades acadêmicocientíficas. São docentes experientes no ensino da pós-graduação, pois a maioria atua nesse segmento da carreira acadêmica há mais de dez anos. 
4. A comunidade estudada teve sua formação acadêmica básica principalmente na área das ciências biológicas, com destaque para a medicina. Quanto à categoria temática que atuam, de acordo com o DeCS - Descritores em Ciências da Saúde, destacam-se as especialidades "Epidemiologia e Bioestatística" e "Administração e Planejamento de Saúde".

5. Os docentes estudados são formados no Brasil, com predominância no Estados de São Paulo e do Rio de Janeiro. No exterior, a formação em graduação e titulação em pós-graduação ocorreu em menor escala, principalmente nos Estados Unidos, para o mestrado, e na Inglaterra e França, para o doutorado.

\section{Uso da internet}

6. A quase totalidade $(94,9 \%)$ da comunidade acadêmica estudada utiliza a internet para suas atividades acadêmico-científicas, e grande parte o faz com propósitos principalmente de comunicação, acessando diariamente o correio eletrônico. Essa comunidade considera dominar as principais ferramentas, com experiência acumulada durante cerca de cinco anos pelo uso da internet em suas atividades diárias.

7. Os que não utilizam a internet $(5,1 \%$ do total de docentes) alegam motivos geralmente ligados à falta de infra-estrutura de redes e equipamentos e de habilidade para esse fim, além de questões de caráter subjetivo, como aversão a novas tecnologias, falta de tempo e também a facilidade de conseguir de seus colegas o que 
precisam. Apesar disso, acenam com a possibilidade de vir a usá-la em curto ou médio prazos.

8. A relação entre o uso da internet e a idade dos docentes se comprovou quando os que não a utilizam são principalmente os que estão acima dos 60 anos.

9. Houve associação entre o uso da internet e a área do conhecimento, havendo maior porcentagem de não-usuários na área de humanas.

10. Houve associação entre o uso da internet e o tempo dedicado às atividades de pesquisa e de ensino. Pode-se afirmar que o pesquisador que dedica grande parte do seu tempo ao ensino tende a usar menos a internet.

11. O correio eletrônico é apontado como o recurso mais utilizado pela comunidade estudada, possibilitando influência positiva na comunicação entre os pesquisadores e propiciando melhoria na condução de pesquisas em colaboração. Isto poderia trazer forte impacto ao conhecimento da saúde pública.

12. A web foi o recurso mais utilizado depois do correio eletrônico, sendo que seu maior benefício foi a busca e obtenção de informações bibliográficas e de textos completos dos documentos. Os demais recursos da internet (grupos e listas de discussão, chats e teleconferências) ainda são pouco utilizados pela comunidade acadêmica brasileira, assim como acontece em outros países.

13. Quanto à escolha do documento para publicação dos resultados de pesquisa, pode-se afirmar que publicar no formato exclusivamente eletrônico ainda é atividade pouco realizada no meio acadêmico-científico. Ainda há a predominância dos 
formatos impressos, sendo principalmente artigos de periódicos nacionais. Nota-se crescente produção de documentos eletrônicos para as contribuições em congressos, simpósios etc.

14. A consulta aos catálogos das bibliotecas foi apontada como maior benefício da internet. No entanto, as bibliotecas devem divulgar mais os demais serviços on-line de busca e obtenção da informação que podem oferecer aos docentes. Pode-se argumentar que, na época do levantamento de dados para o presente estudo, essa comunidade ainda não contava com os serviços remotos de suas bibliotecas.

15. Apesar da idéia de que a internet veio para facilitar as atividades dos pesquisadores, os resultados desta pesquisa mostram que esses usuários sentem-se inseguros quanto às rápidas mudanças nos softwares, sentindo dificuldade para encontrar informações e estressados com o excesso de informação disponível.

16. Pode-se afirmar que a intenet tem seu espaço garantido no dia-a-dia da vida acadêmica, pois facilita as atividades de ensino e de pesquisa científica. A comunidade acadêmico-científica utiliza cada vez mais a internet, considerando-a uma fonte importante de informação, e tem consultado menos publicações impressas desde que passou a utilizar essa ferramenta.

17. Grande parte da comunidade estudada considera que a internet trouxe a possibilidade de aprendizado quanto ao uso de tecnologias emergentes para o ensino e a pesquisa.

18. A internet beneficiou as atividades de ensino acadêmico em relação à indicação de fontes de informações aos alunos, à obtenção de informações para 
preparar e ministrar aulas, além de ser um canal eficiente para comunicação entre docentes e alunos. A orientação de teses foi o aspecto mais positivo apontado quanto à inserção das redes eletrônicas no ensino de pós-graduação.

19. Os docentes não se mostraram muito satisfeitos com a infra-estrutura de redes eletrônicas em suas instituições. Nem todos os docentes que contam com infraestrutura de rede nas instituições têm computador pessoal e acesso adequado à internet para desenvolvimento de suas atividades.

20. Poucos docentes obtêm treinamentos e ajuda técnica para uso adequado dos recursos tecnológicos.

Finalmente, os resultados desta pesquisa sobre a influência das novas tecnologias da informação nas atividades acadêmico-científicas dos docentes da área de saúde pública no Brasil mostraram que a internet afeta significativamente o ciclo da comunicação científica, não somente na rapidez com que a informação pode ser recuperada, mas também na comunicação entre os pesquisadores, tida como a etapa que mais passou por mudanças desde o recente advento da internet no mundo acadêmico brasileiro.

Este estudo sobre o efeito da internet na comunidade científica em saúde pública pretendeu contribuir, juntamente com tantos outros que proliferam na literatura sobre o assunto, para um melhor entendimento das mudanças que a internet vem produzindo na vida acadêmica.

Estudos futuros poderão investigar o impacto da internet no mundo acadêmicocientífico com enfoque em estudos longitudinais, que precisam ser baseados em 
observações permanentes. Esses estudos devem propiciar respostas às necessidades de informação do pesquisador em um ambiente tecnológico que passa por muitas e rápidas mudanças, podendo subsidiar o cientista da informação no desafio de determinar como os produtos do ambiente tecnológico podem melhor atender às necessidades de informação de uma comunidade acadêmico-científica. 


\section{REFERÊNCIAS}

Abels EG. The e.mail reference interview. RQ 1996; (spring):345-58.

Alonso WJ, Fernandez-Juricic E. Regional network raises profile of local journals. Nature 2002; 415: 471-2.

Andrade M T D de, Abdalla, ERF, Cuenca, AMB, Hussein, FS, Siqueira, AAF de, Tananka, A C d’A, França Junior, I. Influência das novas tecnologias no acesso a serviços de informação pelos docentes da área de sáude pública. Inf \& Soc [Periódico on-line] 2003;13(1)] Disponível em: [21 julho 2003]

http://www.informacaoesociedade.ufpb.br

Andrade MTD de. Pesquisa científica em saúde pública: produtividade da comunidade acadêmica brasileira 19983-1989. São Paulo, 1992. [ [Tese de Doutorado - Escola de Comunicações e Artes da USP].

Applebee A, Clayton P, Pascoe C. Australian academic use of internet. Internet Res: Eletronic Network Applic Policy 1997; 7(2):85-94.

Applebee A, Clayton P, Pascoe C, Bruce H. Australian academic use of internet: implication for university administrators. Internet Res: Eletronic Network Applic Policy 2000; 10(2):141-9.

Araujo WJ de. Ferramentas para promoção em web sites de unidades de informação. R Bibliotecon Brasilia 1999/2000; 23/24 (1 esp): 69-88. 
Ash JS. Factors affecting the diffusion of online end user literature searching. Bull Med Libr Ass 1999; 87 (1): 58-66.

Barreto A de A Mudança estrutural no fluxo do conhecimento: a comunicação eletrônica. Ci. Inf. 1998; 27 (2):122-7.

Barreto A de A. A condução da informação. S Paulo Perspect 2002; 16 (3):67-74.

BIREME. Projeto Biblioteca Virtual em Saúde. São Paulo, 2002. Disponível em: [21 julho 2003] http://www.bireme.br.

Botelho EJA O impacto da internet sobre a comunicação científica informal entre pesquisadores de administração. Brasilia; 1997. [Tese de Doutorado - Universidade de Brasilia]

Bruce H. Internet and academic teaching in Australia. Educ Inf 1995; 13:177-91.

Bruce H. User satisfaction with information seeking on the internet. J Amer Soc Inf Sc 1998; 49(6):541-56

Bruce $\mathrm{H}$. Perceptions of the internet: what people think when they search the internet for information. Internet Res-Elect Network Applic Policy 1999;9(3):187-99.

Budd JM, Connaway LS. University faculty and networked information: results of a survey. J Amer Soc Inf Sci 1997; 48 (9): 843-52

Bushallow-Wilbur L, Vinney G, Whitcomb F. Eletronic mail reference service: a study. $R Q 1996$ (Spr):359-71.

CAPES. Coordenação de Aperfeiçoamento de Pessoal de Nível Superior. Programas de pós-graduação, por áreas. [informação on-line]. Brasilia, 2001a. Disponível em <http:www.capes.gov.br> em [01 jun 2001]. 
CAPES. Coordenação de Aperfeiçoamento de Pessoal de Nível Superior. Dados da pós-graduação. [informação on-line]. Brasilia, 2001b. Disponível em <http:www.capes.gov.br/scripts/SelecionaAnoDadosPosGraduacao.idc> em [03 set 2001].

CAPES. Coordenação de Aperfeiçoamento de Pessoal de Nível Superior. Evolui qualidade da pós-graduação brasileira. Noticias CAPES, 30 ago 2001c.

CAPES. Coordenação de Aperfeiçoamento de Pessoal de Nível Superior. Indicadores. [informação on-line]. Brasilia, 2002. Disponível em <http:www.capes.gov.br> em 01 jun 2002.

Castellani M R. Cultura organizacional e tecnologia da informação: um estudo do uso da Internet na atividade de pesquisa em duas unidades da USP. São Paulo, 1998. [Dissertação de Mestrado - Faculdade de Economia, Administração e Contabilidade da USP]

Castells M. A sociedade em rede. São Paulo; Paz e Terra; 1999.

Castilho Filho AFF de. Avaliação do uso de novas tecnologias de informação nas empresas: internet, intranet e extranet: estudo de casos. São Paulo; 1998.

[Dissertação de Mestrado - Escola Politécnica da USP]

Castro RCFC. Comunicação Científica na área de saúde pública: perspectivas para a tomada de decisão em saúde baseada em conhecimento. São Paulo; 2003. [Tese de Doutorado - Faculdade de Saúde Pública da USP]

Christóvão HT. Da comunicação informal à comunicação formal: identificação da frente de pesquisa através de filtros de qualidade. Ci. Inf 1979; 8:3-36.

Cianconi R. Gestão da informação na sociedade do conhecimento. 2a. ed. Brasilia, SENAI/DN, 2001. 
Cobb S, Baird SB. Oncology nurse's use of the internet for continuing education. J Continuing Educ Nurs 1999; 30(5):199-202.

Coffin RJ, Maclntyre PD. Motivational influences on computer-related affective states. Comput Human Behav 1999; 15:549-69.

Cuenca AMB. O usuário final da busca informatizada: avaliação da capacitação no acesso a bases de dados em biblioteca acadêmica. Ci Inf 1999: 28 (3): 231-8

Cuenca AMB, Alvarez M do C A, Ferraz MLE de F, Abdalla ERF. Capacitação no uso das bases Medline e Lilacs: avaliação de conteúdo, estrutura e metodologia. Ci Inf 1999: 28 (3): 338-43.

Cuenca AMB, Alvarez M do C A, Ferraz MLE de F, Garbin VL. O usuário remoto de uma biblioteca acadêmica na área de saúde pública. Inf \& Soc [periódico on-line] 2003; 13 (2). Disponível em [http://www.informacaoesociedade.ufpb.br]

Cunha MB da. Construindo o futuro: a biblioteca universitária em 2010. Ci. Inf. 2000; 29 (1):71-89.

Falcão D. Informação demais adoece. Folha de São Paulo, Supl. Equilibrio, 21 set 2000, p.11

FAPESP. Acesso livre e gratuito. Pesq Fapesp 2003; (fev):24-5.

Ferreira R da S A sociedade da informação no Brasil: um ensaio sobre os desafios do Estado. Ci. Inf 2003; 32(1):36-41

Ferreira SMSP. Redes eletrônicas e informação: abordagem Sense-Making para estudo de comportamento de usuários do Instituto de Física da USP. São Paulo, 1995. [Tese de Doutorado - Escola de Comunicações e Artes da USP] 
Figueira Netto S C. A comunicação científica de redes de computadores: a experiência de pesquisadores brasileiros. Rio de Janeiro; 1994. [Dissertação de Mestrado em Ciência da Informação - UFRJ/ECO - CNPq/IBICT].

Fontes C de A. Usos e efeitos da Internet na prática bibliotecária: estudo exploratório junto ao Sistema Integrado de Bibliotecas da Universidade de São Paulo (SIBi/USP). São Paulo; 2001. [Dissertação de Mestrado - Escola de Comunicação e Artes da USP]

FGV - Fundação Getúlio Vargas. Centro de Políticas Sociais. Mapa da exclusão digital. São Paulo; 2003. Disponível em http://www2.fgv.br/ibre/cps/mapa_exclusao [16 fev 2004]

Fundação IBGE . Resultados preliminares do recenseamento geral do Brasil: 2001. Brasília; 2001.

Garattoni B. Saiba navegar sem estar conectado à rede. Folha de S. Paulo. Cad Informática, 17 jan 2001. p. F6.

Garvey WD. Communication: the essence of science. Oxford: Pergamon Press; 1979.

Harrison TM, Stephen TD. The electronic journal as the heart of online schoplarly community. Libr Trends 1995: 43(4):592-608.

Hollander SM, Martin ER. Public health professionals in the Midwest: a profile of connectivity and information technology skills. Bull Med Libr Ass 1999; 87(3):329-36.

Hurd JM. The transformation of scientific communication: a model for 2020. J Am Soc Inf Sc 2000; 51(14):1279-83. 
Iturri J. Ciberespaço e negociações de sentido: aspectos sociais da implementação de redes digitais de comunicação em instituições acadêmicas de saúde pública. Cad Saúde Pública [periódico online] 1998; 14 (4). Disponível em http://www.scielo.br

Jacobs N. Academic researchers' use of the internet, and their consequent support requirements. Libr Inf Res News 1998; 70(22):30-4

Jordaan M, Jones R. Adoption of Internet technology by UK postgraduate centres: a questionary survey. Health Libr Rev 1999; 16:166-73.

Koehler W. An analysis of web page and web site constancy and permanence. J Am Soc Inf 1999; 50 (2): 162-80.

Korner EJ, Oinonen MJ, Browne RC. The power of collaboration: using internet-based tools to facilitate networking and benchmarking within a consortium of academic health centers. J Med Syst 2003; 27(1):47-56.

Lacher D, Nelson E, Bylsma W, Spena R. Computer use and needs of internists: a survey of members of the American College of Physicians - American Society of Internal Medicine. JAMIA 2000; 7:453-6

Lally E. A researcher's perspective on eletronic scholarly communication. Online Inf Rev 2001; 25(2):80-7.

Lawrence S. Free online availability substantially increases a paper's impact. Nature. Debates available on http://www.nature.com/nature/debates/eaccess/Articles/lawrence.html on 15/07/2003.

Lawrence S, Giles CL. Searching the world wide web. Science [periodical online] 1998; 280: 98-1000. Availableon < http://www.sciencemag.org> 
Lawrence S, Giles CL. Accessibility of information on the web. Nature [periodical online] 1999; 400: 107-9. Available <http://www.nature.com> [

Lazinger SS, Bar-Ilan J, Peritz BC. Internet use by faculty members in various disciplines: a comparitive study. J Amer Soc Inf Sci 1997; 48 (6):508-18.

Liebscher P, Abels EG, Dennan D. Factors that influence the use of eletronic netwrks by science and engeneering faculty at samall institutions. J Am Soc Inf Sc 1997; 48 (6) 496-507.

Lubanski A, Matthew L. Socio-economic impact of the internet in the academic research environment. Assignation 1998; 15(4):512.

Macedo ND de, Modesto F. Equivalências: do serviço de referência convencional a novos ambientes de redes digitais em bibliotecas. $R$ Bras Bibliotecon Doc, Nova Série 1999; 1 (1):55-72.

Marchiori PZ. Contribuição da tecnologia para o desenvolvimento da produção científica e da publicação eletrônica. Recife, 2002. [Apresentação no 12o. Seminário Nacional de Bibliotecas Universitárias, 21-25 out 2002 - Mesa Redonda]

Marcondes $\mathrm{CH}$, Sayão LF. Integração e interoperabilidade no acesso a recursos informacionais eletrônicos em C\&T: a proposta da Biblioteca Digital Brasileira. Ci Inf $2001 ; 30: 24-33$.

Meadows AJ. A comunicação científica; tradução de A A Briquet de Lemos. Brasília: Briquet de Lemos Livros; 1999.

Meis L de, Velloso A, Lannes D, Carmo MS, Meis C de. The growing competition in Brazilian science: rites of passage, stress and burnout. Brazilian J Med Biol Res 2003; 36: $1135-41$. 
Melgoza P, Mennel PA, Gyeszly SD. Information overload. Collection Building 2002; 21(1):32-42.

Menou MJ. Impacto da Internet: algumas questões conceituais e metodológicas, ou como acertar um alvo em movimento atrás da cortina de fumaça [periódico on-line]. DataGramaZero: Rev Cienc Inf [Periódico on-line] (dez) 1999. Disponível em http://www.dgz.org.br/Atual/Art_06.htm

Miranda ALC de, Paker A, Oliveira A de, Barreto, A de A, Pacheco FF, Mello JM de, Coelho Netto Jt, Senra N de C, Jambeiro O, Chastinet Y. Os conteúdos e a Sociedade da Informação no Brasil. DataGramaZero: Rev Cienc Inf [Periódico online] 2000; 1(5). Disponível em < http://www.dgz.org.br/out2000/Art_03.htm >

Molineux RE, Williams RV. Mesuring the internet. Ann Review Inf Sci Technol 1999; 34: $287-339$

Moran JM Como utilizar a internet na educação. Ci Inf 1997; 26 (2):146-53.

Nahuz F. World wide web: aspectos teóricos dos mecanismos de busca. Inf \& Soc 1999; 9 (2):243-54.

Noronha DP. Pós-graduação em saúde pública: análise de dissertações de mestrado e teses de doutorado (1990-1994). São Paulo, 1996. [Tese de Doutorado Faculdade de Saúde Pública da USP]

Palmquist RA, Kim K-S. Modeling the users of information systems: some theories and methods. Ref Librarian 1998; (60): 3-25.

Poblacion DA, Duarte JG. Comunicação da informação científica entre os pesquisadores. Intercom (61): 47-61, 1989. 
Powell J, Fox E A. Multilingual federated searching across heterogeneous collections. D-Lib Magazine [on-line] Sep 1998. Available < http://www.dlib.org/dlib/september98/powell/09powell.html >

Repman J \& Carlson RD. Surviving the storm: using metasearch engines effectively. Comput Libr [periodical online]1999; 19 (5). Available http://repmancarlson.html [02/10/2000]

Rosen LD, Sears DC, Weil MM. Computerphobia. Behav Res Methods, Instrum Comp 1987; 19(2):167-79.

Rousseau GK, Rogers WA Computer usage patterns of university faculty members across the life span. Comput Hum Behav 1998; 14(3): 417-28.

Sampaio MIC, Grandi MEG, Noronha DP, Cuenca AMB, Villela COM, Moraes C, Barsotti R. Uso da Internet em bibliotecas acadêmicas: uma proposta para estabelecimento de política - primeira fase. Inf \& Soc [on-line] 2001; 11(1).

Savolainen R. Use studies of electronic networks: a review of empirical research approaches and challenges for their development. J Doc 1998; 54 (3):332-51.

Savolainen R. Embarking on the internet: what motivates people? Alisb Proc 2000; 52:185-93.

Schauder D. Eletronic publishing os professional articles. J Am Soc Inf Sc 1994; 45 (2): $73-100$

Selwyn N. Creating a connected community? Teachers's use of an electronic discussion group. Teach Coll Rec 2000; 102 (4): 750-78.

Sena NK. Open archives: caminho alternativo para a comunicação científica. Ci Inf 2000; 29(3): 71-78 
Shannon DM, Bradshaw CC. A comparison of response rate,response time, and costs of mail and eletronic surveys. J Exp Educ 2002; 70(2): 179-92.

Silva S M da. Aspectos culturais do uso da Internet em atividade de pesquisa acadêmica na Escola Politécnica da Universidade de São Paulo. São Paulo, 1997. [Dissertação de Mestrado - Faculdade de Economia, Administração e Contabilidade da USP]

Simon I. Universidade diante das novas tecnologias de informação e comunicação. In: Anais do Simpósio Internacional Universidade e Novas Tecnologias: Impactos e Implicações, São Paulo,1998. São Paulo: Universidade de São Paulo, 1999. p.47-49.

Souza M da PN de. Efeitos das tecnologias da informação na comunicação de pesquisadores da Embrapa. Ci Inf 2003; 32(1):135-43.

Studt T. How researchers use the Internet. $R$ \& D Magazine 1998; (Nov):20-27.

Studt T. Reseachers integrate Internet tools into their work. $R \& D$ Magazine 2000; (Jun): E13-E14.

Stumpf IRC. O uso da Internet na pesquisa universitária: o caso da UFRGS. $R$ Bibliotecon Brasilia 1997; 21 (1): 189-200.

Targino M das G. Divulgação de resultados como expressão da função social do pesquisador. $R$ Bibliotecon Brasilia 1999/2000; 23/24 (3): 237-66.

Targino M das G, Garcia JCR. Ciência brasileira na base de dados do Institute for Scientific Information (ISI). Ci. Inf. 2000; 29 (1): 103-117

Terra JCC, Gordon C. Portais corporativos: a revolução na gestão do conhecimento. São Paulo: Negocio Editora; 2002. 
Vargas J I. A informação e as redes eletrônicas. Ci Inf 1994; 23 (1): 7-8.

Vianna LW, Carvalho MAR de, Melo MPC, Burgos MB. Doutores e teses em ciências sociais. Dados [Periódico on-line]1998; 41 (3). Disponível em http://www.scielo.br, em 2.6.2003

Voorbij HJ. Searching scientific information on the internet: a Dutch academic user survey. J Am Soc Inf Sci 1999; 50(7):598-615.

Walsh JP, Kucker S, Maloney NG. Connecting minds: computer-mediated communication and scientific work. J Am Soc Inf Sc 2000; 51 (14): 1295-305

Wang P. Methodologies and methods for user methods for user behavioral research. Annual Rev Inf Sc Technol 1999; 34: 53-97

Weingart SJ, Anderson J A. When questions are answers: using a survey to achieve faculty awareness of the library's electronic resources. C Coll \& Res Libr 2000; 61:12734.

Wikgren M. Health discussions on the internet: a study of knowledge communication through citations. Libr \& Inf Sc Res 2001; 23(4):305-17.

Zhang Y. Scholarly use of internet-based electronic resources: a survey report. Libr Trends 1999; 47(4):746-70.

Zhang Y. Using the internet for survey research: a case study. J Am Soc Inf Sci 2000; 51(1):57-78. 
ANEXO 1 - Programas de Pós-Graduação em Saúde Coletiva, credenciados na CAPES- Fundação Coordenação de Aperfeiçoamento de Pessoal de Nível Superior, Brasil, em 2001.

\begin{tabular}{|c|c|c|c|}
\hline $\begin{array}{l}\text { Programa de Pós- } \\
\text { Graduação em }\end{array}$ & IES - Instituição de Ensino Superior & Nível & UF \\
\hline Epidemiologia & UFRGS - Univ. Federal do Rio Grande do Sul & $\begin{array}{l}\text { Mestrado } \\
\text { Doutorado }\end{array}$ & RS \\
\hline Epidemiologia & UNIFESP - Universidade Federal de São Paulo & Mestrado & SP \\
\hline Epidemiologia & UFPEL - Universidade Federal de Pelotas & $\begin{array}{l}\text { Mestrado } \\
\text { Doutorado }\end{array}$ & RS \\
\hline Medicina Preventiva & USP - Faculdade de Medicina & $\begin{array}{l}\text { Mestrado } \\
\text { Doutorado }\end{array}$ & SP \\
\hline $\begin{array}{l}\text { Saúde na } \\
\text { Comunidade }\end{array}$ & USP/RP - Faculdade de Medicina de Ribeirão Preto & Mestrado & SP \\
\hline Saúde Coletiva & UNESP/BOT- Faculdade de Medicina de Botucatu & Mestrado & SP \\
\hline Saúde Coletiva & $\begin{array}{l}\text { UFBA - Universidade Federal da Bahia / Instituto de } \\
\text { Saúde Coletiva }\end{array}$ & $\begin{array}{c}\text { Mestrado } \\
\text { Doutorado } \\
\text { Profissionalizante }\end{array}$ & BA \\
\hline Saúde Coletiva & $\begin{array}{l}\text { UERJ - Universidade do Estado do Rio de Janeiro / } \\
\text { Instituto de Medicina Social }\end{array}$ & $\begin{array}{l}\text { Mestrado } \\
\text { Doutorado }\end{array}$ & RJ \\
\hline Saúde Coletiva & $\begin{array}{l}\text { UNICAMP - Universidade Estadual de Campinas / } \\
\text { Faculdade de Ciências Médicas }\end{array}$ & $\begin{array}{c}\text { Mestrado } \\
\text { Doutorado } \\
\text { Profissionalizante }\end{array}$ & SP \\
\hline Saúde Coletiva & UEFS - Universidade Estadual de Feira de Santana & Mestrado & BA \\
\hline Saúde Coletiva & UFRJ- Universidade Federal do Rio de Janeiro & Mestrado & RJ \\
\hline Saúde Coletiva & UFPE- Universidade Federal de Pernambuco & Mestrado & PE \\
\hline Saúde Coletiva & UEL- Universidade Estadual de Londrina & Mestrado & PR \\
\hline Saúde Coletiva & FUFMS- Fundação Universidade Mato Grosso do Sul & Mestrado & MS \\
\hline Saúde Coletiva & ULBRA - Universidade Luterana do Brasil & Mestrado & RS \\
\hline $\begin{array}{l}\text { Saúde da Mulher e } \\
\text { da Criança }\end{array}$ & FIOCRUZ - Instituto Fernandes Figueira & $\begin{array}{l}\text { Mestrado } \\
\text { Doutorado }\end{array}$ & RJ \\
\hline Saúde e Ambiente & UFMA- Universidade Federal do Maranhão & Mestrado & MA \\
\hline Saúde e Ambiente & UFMT- Universidade Federal Mato Grosso & Mestrado & MT \\
\hline Saúde Pública & FIOCRUZ - Escola Nacional de Saúde Pública & $\begin{array}{l}\text { Mestrado } \\
\text { Doutorado }\end{array}$ & RJ \\
\hline Saúde Pública & USP - Faculdade de Saúde Pública & $\begin{array}{l}\text { Mestrado } \\
\text { Doutorado }\end{array}$ & SP \\
\hline Saúde Pública & UFC- Universidade Federal do Ceará & Mestrado & CE \\
\hline Saúde Pública & UFMG- Universidade Federal Minas Gerais & Mestrado & MG \\
\hline Saúde Pública & FIOCRUZ - NESC/CPqAM - & Mestrado & PE \\
\hline Saúde Pública & UFSC- Universidade Federal Santa Catarina & Mestrado & SC \\
\hline
\end{tabular}




\section{ANEXO 2 - DISQUETE}

Questionário eletrônico em HTML, enviado por e-mail, ao docente dos Programas de PósGraduação em Saúde Coletiva, Brasil, 2002. 
ANEXO 3 - Questionário (cont.)

\section{I - CARACTERÍSTICAS DO DOCENTE}

Esta parte do questionário tem por objetivo a caracterização do docente que atua na pósgraduação na área de saúde pública/coletiva

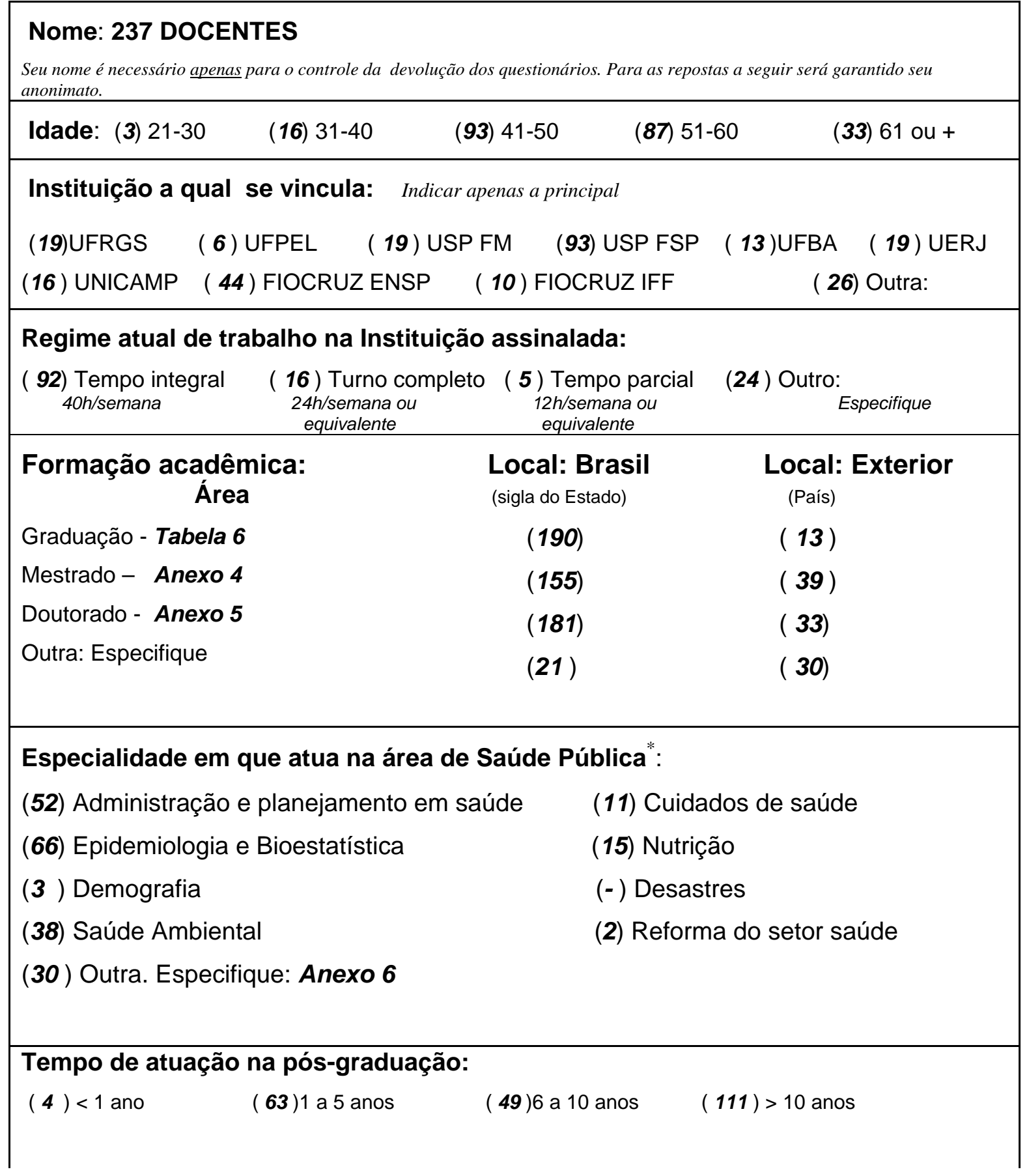

\footnotetext{
* Esta classificação está de acordo com a categoria Saúde Publica, definida para o vocabulário DeCS (Descritores em Saúde Pública) da BIREME (2001).
} 
ANEXO 3 - Questionário (cont.)

Distribuição do seu tempo de trabalho na Instituição no período acima assinalado: \% Ensino Ver Tabela 12

\% Pesquisa (incluir orientação de teses)

\% Extensão

\% Atividades administrativas (incluir participação em Colegiados)

\section{II - USO DA INTERNET}

Este módulo do questionário tem por objetivo saber se você utiliza os recursos da Internet para suas atividades de ensino e de pesquisa.

\section{1-Você utiliza Internet para atividades acadêmico-científicas?}

( 225 ) Sim

( 12 ) Não

\section{SE VOCÊ RESPONDEU “NÃO” responda as questões 2 e 3.}

\section{Indique o principal motivo:}

(2) Não conto com os equipamentos necessários funcionando em rede

(4) Não tenho conhecimento suficiente de informática para o uso da Internet

(3) Não sei navegar na Internet

(4) Não me adaptei a essas novas tecnologias

(8) Consigo o que preciso sem ter que usar a Internet

(7) Consigo o que preciso da Internet por meio de "colaboradores"

( - ) Outro . Indique:

\section{3- Você vê alguma possibilidade de vir a usar a Internet :}

(6 ) a curto prazo ( 5 )a médio prazo ( - )a longo prazo ( 1 )nenhuma possibilidade

\section{Use o espaço abaixo caso queira deixar comentários sobre a Internet}

\section{"uso para comunicação profissional"}

"pesquisa na internet não me faz falta"

"é instrumento útil"

MUITO OBRIGADA PELA COLABORAÇÃO ! 
ANEXO 3 - Questionário (cont.)

SE VOCÊ RESPONDEU “SIM” responda as questões 4 a 16.

4- Há quanto tempo utiliza a Internet para suas atividades acadêmicocientíficas?

(3) - que 1 ano

(8)1 ou 2 anos

(52)3 ou 4 anos

(139) + que 5 anos

\section{5-Quanto ao grau de experiência com a Internet, você se considera :}

( 33 ) um iniciante ( 137 ) com domínio das principais ferramentas (29) com domínio total

6- Indique com qual periodicidade utiliza cada recurso da Internet relacionado abaixo:

\begin{tabular}{|c|c|c|c|c|c|c|c|}
\hline \multirow{3}{*}{ Recursos da Internet } & \multirow{3}{*}{$\begin{array}{l}\text { Desconhe } \\
\text { ço }\end{array}$} & \multirow{3}{*}{$\begin{array}{c}\text { Conheço } \\
\text { mas não } \\
\text { utilizo }\end{array}$} & \multicolumn{5}{|c|}{$\underline{\text { Utilizo }}$} \\
\hline & & & \multirow{2}{*}{$\begin{array}{c}\text { No. } \\
\text { de } \\
\text { vezes }\end{array}$} & \multicolumn{4}{|c|}{ período } \\
\hline & & & & 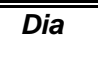 & $\begin{array}{c}\text { Sem } \\
\text { ana }\end{array}$ & Mes & 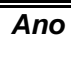 \\
\hline Correio eletrônico (E-mail) & - & - & & 207 & 9 & 1 & 1 \\
\hline WWW - World Wide Web (sites) & 1 & 3 & & 125 & 66 & 14 & - \\
\hline $\begin{array}{l}\text { Newsgroups - Grupos e Fóruns } \\
\text { de Discussão }\end{array}$ & 10 & 198 & & 23 & 30 & 24 & 5 \\
\hline Salas de bate-papo (Chats, ICQ) & 14 & 152 & & 3 & 7 & 7 & 5 \\
\hline Teleconferências & 18 & 140 & & - & 1 & 10 & 18 \\
\hline $\begin{array}{l}\text { FTP - Transferência e obtenção } \\
\text { de arquivos }\end{array}$ & 14 & 40 & & 39 & 57 & 36 & 12 \\
\hline Outro. Especifique: & 4 & 5 & & 3 & 5 & - & - \\
\hline
\end{tabular}

\section{III- A INTERNET NA PESQUISA E NO ENSINO}

Este módulo destina-se a conhecer como a Internet vem afetando seu "dia a dia" acadêmico 
ANEXO 3 - Questionário (cont.)

7- Quais das atividades abaixo foram influenciadas - para melhor ou pior - com o uso da Internet?

\begin{tabular}{|l|l|l|l|l|}
\hline \multirow{2}{*}{ Atividades de comunicação } & \multicolumn{3}{|c|}{ SIM } & $\begin{array}{l}\text { NÃO } \\
\text { utiliza } \\
\text { Internet }\end{array}$ \\
\cline { 2 - 6 } & Melhorou & Piorou & $\begin{array}{c}\text { Não } \\
\text { alterou }\end{array}$ & \\
\hline Contatos com colegas da sua Instituição & 174 & 8 & 36 & 3 \\
\hline Contatos com colegas de outras Instituições no Brasil & 213 & 1 & 8 & - \\
\hline Contatos com colegas de outros países & 193 & - & 15 & 10 \\
\hline Contatos com editores científicos & 141 & 1 & 60 & 16 \\
\hline Contatos com órgãos de fomento & 167 & 5 & 39 & 7 \\
\hline Discussão com grupos de pesquisa & 114 & 1 & 62 & 37 \\
\hline Outro. Indique: 20 & \multicolumn{2}{|l}{} & \\
\hline
\end{tabular}

8-Quais das atividades abaixo, referentes à busca da informação, foram influenciadas - para melhor ou pior - com o uso da Internet?

\begin{tabular}{|c|c|c|c|c|}
\hline \multirow[b]{2}{*}{ Forma de busca da informação } & \multicolumn{3}{|c|}{ SIM } & \multirow[b]{2}{*}{$\begin{array}{l}\text { NÃO } \\
\text { utiliza } \\
\text { Internet }\end{array}$} \\
\hline & Melhorou & Piorou & $\begin{array}{l}\text { Não } \\
\text { alterou }\end{array}$ & \\
\hline Busca em citações em artigos/livros & 189 & - & 20 & 12 \\
\hline Leitura de publicações recentes & 198 & - & 17 & 6 \\
\hline Obtenção de referências com colegas & 180 & 1 & 31 & 7 \\
\hline Obtenção de material inédito com colegas & 163 & 1 & 36 & 13 \\
\hline Realização de levantamentos bibliográficos & 200 & 1 & 11 & 9 \\
\hline $\begin{array}{l}\text { Obtenção de documentos/artigos com textos } \\
\text { completos }\end{array}$ & 191 & 1 & 22 & 6 \\
\hline Consulta a catálogos de bibliotecas & 169 & 1 & 32 & 16 \\
\hline Solicitação de serviços da biblioteca & 123 & - & 62 & 30 \\
\hline Outra. Indique: & 2 & - & - & 4 \\
\hline
\end{tabular}


ANEXO 3 - Questionário (cont.)

9- Assinale as formas que você mais tem utilizado para divulgação dos seus trabalhos, nos últimos 3 anos.

\begin{tabular}{|l|l|l|}
\hline $\begin{array}{l}\text { Formas de divulgação } \\
\text { (Assinale uma ou ambas as colunas) }\end{array}$ & Impresso & Eletrônico \\
\hline Artigo em periódico de circulação nacional & 211 & $\mathbf{9}$ \\
\hline Artigo em periódico de circulação internacional & 143 & $\mathbf{7}$ \\
\hline Capitulo de livro & 148 & $\mathbf{5}$ \\
\hline Livro & $\mathbf{8 1}$ & $\mathbf{5}$ \\
\hline Trabalho completo em anais de congressos & 122 & $\mathbf{2 6}$ \\
\hline Resumos em anais de congressos & 159 & $\mathbf{2 9}$ \\
\hline Outra & $\mathbf{6}$ & $\mathbf{3}$ \\
\hline $\begin{array}{l}\text { Indique: Textos; relatórios de pesquisa; palestras e mesas redondas } \\
\text { em congressos; materiais para ensino; Jornal da USP; comunicações } \\
\text { em congressos; artigo encomendado. }\end{array}$ & & \\
& & \\
\hline
\end{tabular}

10- Quais das atividades de PESQUISA abaixo foram influenciadas - para melhor ou pior - com o uso da Internet?

\begin{tabular}{|c|c|c|c|c|}
\hline \multirow[b]{2}{*}{ Atividades de pesquisa } & \multicolumn{3}{|c|}{ SIM } & \multirow[b]{2}{*}{$\begin{array}{l}\text { NÃO } \\
\text { utiliza } \\
\text { Internet } \\
\end{array}$} \\
\hline & Melhorou & Piorou & $\begin{array}{l}\text { Não } \\
\text { alterou }\end{array}$ & \\
\hline Busca de informação bibliográfica & 208 & - & 7 & 6 \\
\hline Coleta de dados para pesquisa & 145 & 1 & 53 & 18 \\
\hline Processamento/tabulação de dados & 88 & - & 86 & 37 \\
\hline Submissão de originais para publicação & 135 & - & 65 & 18 \\
\hline Condução de pesquisas em colaboração & 166 & - & 34 & 12 \\
\hline Emissão de pareceres técnico-científicos & 159 & 4 & 40 & 12 \\
\hline Desenvolvimento de projetos de pesquisa & 152 & - & 49 & 15 \\
\hline $\begin{array}{l}\text { Acompanhamento de projetos de pesquisa dos } \\
\text { seus orientandos }\end{array}$ & 173 & - & 34 & 4 \\
\hline Atividades administrativas referentes à pesquisa & 145 & 2 & 46 & 17 \\
\hline Outra. Indique: & - & - & - & - \\
\hline
\end{tabular}

\footnotetext{
* periódicos com artigos publicados em outro idioma, além do português e/ou indexados em bases de dados internacionais
} 
ANEXO 3 - Questionário (cont.)

11 Quais das atividades de ENSINO abaixo foram influenciadas - para melhor ou pior - com o uso da Internet?

\begin{tabular}{|c|c|c|c|c|}
\hline \multirow{2}{*}{ Atividades de ensino } & \multicolumn{3}{|c|}{ SIM } & \multirow[b]{2}{*}{$\begin{array}{l}\text { NÃO } \\
\text { utiliza } \\
\text { Internet }\end{array}$} \\
\hline & Melhorou & Piorou & $\begin{array}{c}\text { Não } \\
\text { alterou }\end{array}$ & \\
\hline $\begin{array}{l}\text { Busca de informações para preparar ou ministrar } \\
\text { aulas }\end{array}$ & 189 & - & 20 & 8 \\
\hline Indicação de fontes de informações aos alunos & 192 & 1 & 17 & 6 \\
\hline Disponibilização de textos didáticos aos alunos & 148 & - & 52 & 15 \\
\hline Comunicação com os alunos & 158 & 2 & 47 & 7 \\
\hline Atualização do conteúdo de disciplinas & 155 & - & 45 & 10 \\
\hline Avaliação de alunos & 77 & 4 & 97 & 32 \\
\hline Atividades administrativas referentes ao ensino & 169 & 2 & 64 & 20 \\
\hline Outra:7 Indique: & - & - & - & - \\
\hline
\end{tabular}

12- Possui site específico para sua(s) disciplina(s)?

(48) Sim (172) Não 5 não responderam

13- Possui site específico para suas atividades de pesquisa?

(49) Sim (163) Não 13 não responderam

14- Participa de alguma atividade referente à tecnologia de Ensino à Distância?
(43) Sim
(168) Não
14 não responderam 
ANEXO 3 - Questionário (cont.)

\section{VI - BARREIRAS E EXPECTATIVAS DE USO DA INTERNET}

Este módulo tem por objetivo identificar de forma geral as dificuldades e expectativas do docente quanto ao uso da Internet na realização das atividades acadêmico-científicas.

\section{5-Quais recursos oferecidos pela sua Instituição você utiliza para suas} atividades de ensino e pesquisa?

(155) Sala de aula com pontos de Internet para todos (ou maioria) dos alunos

(48) Sala de aula com pelo menos um ponto de Internet

(172) Projetor multimídia (datashow)

(120) Computador portátil (notebook)

(137) Computador individual

(68) Computador compartilhado

(174) Rede local com acesso à Internet

(84) Intranet

(60) Treinamentos

(143) Biblioteca com acesso à Internet

(8) Outro. Indique: "nossa escola está longe de oferecer o que preciso"; "é difícil conseguir projetor e laptop"; "não tenho usado recurso da instituição".

16-Quais dos itens abaixo você considera como barreira para o uso da Internet em suas atividades acadêmico-científicas?

(100) Lentidão no acesso

(88) Falta de ajuda técnica

(78) Equipamentos insuficientes

(57) Equipamentos e softwares desatualizados

(37) Resistência em usar essas tecnologias

(12) Falta de tempo para explorar tudo o que a Internet disponibiliza

(24) Não considera de qualidade os conteúdos da Internet

(69) Dificuldade em encontrar informações na Internet

(24) Excesso de informação na Internet

(11) Não encontra barreira alguma

(2) Outra. Indique: "Excesso de lixo na internet"; " falta de equipamento próprio" 
ANEXO 3 - Questionário (cont.)

\section{Dê sua opinião a respeito das colocações abaixo referentes ao uso da} Internet:

1- discorda totalmente

2- discorda parcialmente

3- neutro

4- concorda parcialmente

5-concorda totalmente

ver Tabela 30

Sempre encontro alguma informação importante na Internet

Tenho consultado menos publicações impressas desde que comecei a usar a Internet

É fácil ficar atualizado consultando a Internet

É mais fácil se comunicar com outros pesquisadores nos dias de hoje com a Internet do que antes

A quantidade de publicações aumentou devido às facilidades da Internet

A qualidade das pesquisas melhorou com a Internet

Venho usando cada vez mais a Internet no decorrer do tempo

A Internet se tornou a fonte de informação mais importante para minhas

atividades

Conheço o que a Internet oferece na minha área de especialização

A Internet trouxe a possibilidade de aprender o uso de tecnologias emergentes para o ensino/pesquisa

Use o espaço abaixo caso queira deixar comentários sobre a Internet nas suas atividades acadêmico-científicas.

Ver Anexo 7

\section{MUITO OBRIGADA PELA COLABORAÇÃO !}

\section{Enviar Cancelar Modificar}




\section{Caro Professor:}

É muito importante para a finalidade desta pesquisa saber o motivo pelo qual você não respondeu o questionário eletrônico enviado para o seu e.mail. Poderia assinalar o motivo:

(26) Não recebeu o questionário eletrônico

(17) Não teve tempo para responder o eletrônico

(6) Não abriu seus e.mails nesse período

(9) Outro:

Respondeu o eletrônico (6)

Excesso de mensagens na caixa de correio eletrônico (4)

Não costuma responder a todas as solicitações por e.mail

Faltaram informações sobre a pesquisa a ser realizada para que o docente se engajasse Problemas com vírus no computador

Problemas com o equipamento

Não teve interesse em responder

Não tem e.mail

Esqueceu-se e acabou perdendo o questionário

Estive fora do país por 2 meses

Tempo solicitado para resposta não compatível com a disponibilidade

Não responderam (20) 


\section{ANEXO 4}

Titulação no Mestrado, segundo áreas temáticas indicadas pelos docentes dos Programas de Pós-Graduação em Saúde Coletiva, Brasil, 2002.

\begin{tabular}{|c|c|c|c|}
\hline Área temática & $\begin{array}{c}\text { No. de } \\
\text { docentes }\end{array}$ & Área temática & $\begin{array}{c}\text { No. de } \\
\text { docentes }\end{array}$ \\
\hline Administração & 3 & Matemática Aplicada & 1 \\
\hline Antropologia & 5 & Medicina (Patologia) & 1 \\
\hline Bioestatística & 1 & Medicina Comunitária & 1 \\
\hline Biofísica & 1 & Medicina Social & 10 \\
\hline Biologia Molecular & 1 & Medicina Tropical & 2 \\
\hline Ciência e Tecnol Alimentos & 3 & Medicina Veterinária & 1 \\
\hline Ciências Políticas & 1 & Medicina (Ginecol. Obstet.) & 1 \\
\hline Ciencias da Saúde & 2 & Medicina (Pneumologia) & 2 \\
\hline Ciências Ambientais & 1 & Microbiologia & 1 \\
\hline Ciências Biológicas & 1 & Microbiologia de Alimentos & 1 \\
\hline Ciências Sociais em Saúde Pública & 1 & Moléstias Infecciosas & 1 \\
\hline Comunicação & 1 & Nutrição & 5 \\
\hline Demografia & 1 & Odontologia & 1 \\
\hline Ecologia Geral & 1 & Planejam Serv de Saúde & 2 \\
\hline Ecologia Humana & 1 & Planejam Urbano Regional & 1 \\
\hline Economia & 2 & Psicologia & 2 \\
\hline Educação & 3 & Saúde Ambiental & 1 \\
\hline Educação em Saúde Pública & 1 & Saúde Coletiva & 8 \\
\hline Engenharia (Sanitária, de Produção) & 1 & Saúde Comunitária & 4 \\
\hline Engenharia Biomédica & 2 & Saúde Materno-Infantil & 1 \\
\hline Engenharia de Produção & 4 & Saúde Pública & 69 \\
\hline Epidemiologia & 7 & Saúde Trabalhador & 1 \\
\hline Ergonomia & 1 & Semiótica & 2 \\
\hline Estatística & 3 & Sociologia & 5 \\
\hline Farmácia & 1 & Sociologia aplicada à Medicina & 1 \\
\hline Medicina (Fisiologia) & 1 & Urbanismo & 1 \\
\hline Geografia & 1 & Zoologia & 2 \\
\hline Hidráulica e Saneamento & 1 & TOTAL & 202 \\
\hline
\end{tabular}




\section{ANEXO 5}

Titulação no Doutorado, segundo áreas temáticas indicadas pelos docentes dos Programas de PósGraduação em Saúde Coletiva, Brasil, 2002.

\begin{tabular}{|c|c|c|c|}
\hline Especialidade & $\begin{array}{c}\text { No. de } \\
\text { vezes } \\
\text { informada }\end{array}$ & Especialidade & $\begin{array}{c}\text { No. de } \\
\text { vezes } \\
\text { informada }\end{array}$ \\
\hline Administração & 1 & Geologia & 1 \\
\hline Administração Pública & 1 & Geoquímica Ambiental & 1 \\
\hline Antropologia & 3 & Ginecologia e Obstetrícia & 1 \\
\hline Arquitetura e Urbanismo & 2 & Health Policy and Administration & 1 \\
\hline Bioestatística & 1 & Medicina & 7 \\
\hline Biologia Celular e Molecular & 1 & Medicina Comunitária & 1 \\
\hline Ciência dos Alimentos & 1 & Medicina Preventiva & 14 \\
\hline Ciências Ambientais & 1 & Medicina Social & 1 \\
\hline Ciências Biológicas & 1 & Medicina Veterinária & 1 \\
\hline Ciências da Saúde & 3 & Microbiologia & 1 \\
\hline Ciências Humanas & 2 & Microbiologia e Imunologia & 1 \\
\hline Ciências Políticas & 1 & Neurociências e Comportamento & 1 \\
\hline Ciencias Socias em Saúde Pública & 1 & Nutrição & 1 \\
\hline Clínica Médica & 3 & Nutrição em Saúde Pública & 3 \\
\hline Comunicação & 1 & Parasitologia Bio-molecular & 1 \\
\hline Demografia Médica & 1 & Patologia & 3 \\
\hline Ecologia Humana & 1 & Patologia Experimental & 1 \\
\hline Economia & 1 & Pediatria & 1 \\
\hline Educação & 1 & Pneumologia & 1 \\
\hline Enfermagem & 1 & Psicologia & 1 \\
\hline Enfermagem de Saúde Pública & 1 & Psicologia Social & 1 \\
\hline Engenharia Biomédica & 5 & Psiquiatria & 2 \\
\hline Engenharia Hidráulica e Sanitária & 1 & Saneamento Ambiental & 1 \\
\hline Epidemiologia & 9 & Saúde Ambienta & 3 \\
\hline Estatística & 1 & Saúde Coletiva & 14 \\
\hline Estruturas Ambientais Urbanas & 1 & Saúde Pública & 106 \\
\hline Filosofia & 2 & Serviços de Saúde Pública & 1 \\
\hline Física & 1 & Sociologia & 5 \\
\hline \multirow[t]{2}{*}{ Geociências } & 1 & Zoologia & 1 \\
\hline & & TOTAL & 229 \\
\hline
\end{tabular}




\begin{abstract}
ANEXO 6
Área de especialização temática do docente dos Programas de Pós-Graduação em Saúde Coletiva, Brasil, 2002, segundo sua percepção, não categorizada como saúde pública no vocabulário DeCS.
\end{abstract}

\begin{tabular}{|c|c|c|c|}
\hline Área de Especialização & $\begin{array}{c}\text { No. de } \\
\text { vezes } \\
\text { informada }\end{array}$ & Área de Especialização & $\begin{array}{c}\text { No. de } \\
\text { vezes } \\
\text { informada }\end{array}$ \\
\hline Antropologia Médica & 2 & Metodologia da Pesquisa & 1 \\
\hline Bioética & 2 & Odontologia em Saúde Pública & 1 \\
\hline Ciência e Tecnologia & 1 & $\begin{array}{l}\text { Paleopatologia / História das } \\
\text { Doenças }\end{array}$ & 1 \\
\hline Ciências Humanas e Saúde & 2 & $\begin{array}{l}\text { Práticas Terapêuticas Não } \\
\text { Convencionais }\end{array}$ & 1 \\
\hline $\begin{array}{l}\text { Ciências Sociais / Metodologia da } \\
\text { Pesquisa }\end{array}$ & 1 & Promoção da Saúde & 7 \\
\hline $\begin{array}{l}\text { Ciências Sociais e Saúde / } \\
\text { Antropologia }\end{array}$ & 2 & Promoção e Educação em Saúde & 1 \\
\hline Clínica Veterinária & 1 & $\begin{array}{l}\text { Promoção da Saúde no } \\
\text { Envelhecimento }\end{array}$ & 1 \\
\hline $\begin{array}{l}\text { Desenvolvimento de Tecnologia } \\
\text { Moderada }\end{array}$ & 1 & Saúde Bucal Coletiva & 1 \\
\hline Educação em Saúde Pública & 2 & Saúde da Criança & 1 \\
\hline $\begin{array}{l}\text { Educação e Promoção da Saúde } \\
\text { Pública }\end{array}$ & 1 & Saúde do Idoso & 1 \\
\hline Entomologia Médica & 2 & Saúde da Mulher e Adolescência & 1 \\
\hline Envelhecimento Humano & 2 & Saúde e Sociedade & 2 \\
\hline Epidemiologia Ocupacional & 1 & Saúde do Trabalho & 2 \\
\hline Ergonomia & 1 & Saúde do Trabalhador & 5 \\
\hline Ética em Saúde Pública & 1 & Saúde Materno-Infantil & 5 \\
\hline Gênero e Saúde & 1 & Saúde Mental & 2 \\
\hline História das Doenças & 1 & Saúde Pública Veterinária & 1 \\
\hline História da Saúde & 1 & Saúde Reprodutiva e Gênero & 2 \\
\hline História Social da Medicina & 2 & Sociologia Histórica da Saúde & 2 \\
\hline Informação em Saúde & 1 & Sociologia da Saúde & 1 \\
\hline Informática em Saúde & 1 & Trabalho, Educação e Saúde & 1 \\
\hline Laboratório de Saúde Pública & 2 & Vigilância em Saúde & 1 \\
\hline Medicina do Trabalho & 1 & Zoonoses & 2 \\
\hline Medicina Tropical & 1 & TOTAL & 54 \\
\hline
\end{tabular}


ANEXO 7 - Opiniões livres deixadas pelos docentes dos Programas de PósGraduação em Saúde Coletiva, Brasil, 2002, sobre o uso da internet em suas atividades acadêmico-científicas.

\begin{tabular}{|c|c|}
\hline No & Comentário livre \\
\hline 1 & $\begin{array}{l}\text { Com a Internet a atividade administrativa recaiu bastante sobre o docente } \\
\text { sobrecarregando suas atividades e por vez duplicando pois, agora além de digitar na } \\
\text { internet é você que tem que enviar para a área acadêmica correspondente. Assim é o } \\
\text { docente agora responsável por quase tota a atividade administrativa }\end{array}$ \\
\hline 2 & $\begin{array}{l}\text { Acho importante. Utilizo principalmente alguns sites sobre nutrição. Sinto que poderia } \\
\text { utilizar mais todos os recursos que ela oferece. Só não o faço por um pouco de } \\
\text { resistência, um pouco por falta de tempo e também porque não tenho muita } \\
\text { paciência. }\end{array}$ \\
\hline 3 & $\begin{array}{l}\text { A Internet ajuda muito em várias atividades, porém não resolveu tudo. Ela é apenas } \\
\text { um instrumento. O docente/pesquisador ainda é o principal agente pensador. }\end{array}$ \\
\hline 4 & $\begin{array}{l}\text { Encontro dificuldades em aprender a usar com benefícios a internet. O processo me } \\
\text { impacienta frequentemente }\end{array}$ \\
\hline 5 & $\begin{array}{l}\text { É 1a revolucão. como a iilula foi para as mulheres na década de } 60 \text { e o viagra para os } \\
\text { homens neste novo século...e 1a revolucão na maneira de interagirmos e nos } \\
\text { comunicar com o mundo, nao só o da ciência. }\end{array}$ \\
\hline 6 & $\begin{array}{l}\text { É preciso liberar o conteúdo das revistas científicas para facilitar o acesso de mais } \\
\text { pessoas. Os editores deveriam buscar outras formas de financiamento das } \\
\text { publicações, hoje pendentes de assinatura. }\end{array}$ \\
\hline 7 & $\begin{array}{l}\text { O excesso de informação, muitas vezes sem o crivo de um conselho editorial polui } \\
\text { muito a rede. Bases como a Scielo são importantes para a pesquisa e a divulgação }\end{array}$ \\
\hline 8 & $\begin{array}{l}\text { Penso que a internet constitui apenas um meio mas não um fim e muito menos } \\
\text { susbstitutivo de procedimentos consagrados. Talvez se consitutia em facilitadora para } \\
\text { alguns procedimentos. }\end{array}$ \\
\hline 9 & $\begin{array}{l}\text { Os sítios (sites) da internet geralmente carecem de organização lógica, implicam a } \\
\text { abertura de páginas com informações aleatórias, superficiais, irrelevantes, } \\
\text { redundantes, incompletas (ausência de sistematização na classificação de } \\
\text { conteúdos), ocasionando perda de tempo e desestimulando a chamada "navegação", } \\
\text { que não deve ser um jogo aleatório em termos do conteúdo apresentado. A } \\
\text { diagramação das páginas dos sítios (sites) é muito ruim, de difícil leitura. }\end{array}$ \\
\hline 10 & Realmente apresento certa resistência ao uso da Informática \\
\hline 11 & $\begin{array}{l}\text { Sou extremamente favoravel ao uso da Internet nas atividades academicas. É uma } \\
\text { tecnologia que aumentou expressivamente o acesso e a troca de informacao } \\
\text { cientifica, quebrando barreiras e aproximando pesquisadores, docentes e alunos de } \\
\text { diferentes lugares. }\end{array}$ \\
\hline
\end{tabular}


Eu uso a internet para comunicação profissional e pessoal, pena que essa alternativa nao apareceu, estou quase gostando dela...

Nossa Escola está longe de oferecer o que as particulares já oferecem...

A busca de bibliográfica e o acesso a publicacões impressas ficaram mais ágil para pesquisadores que habitam em áreas do país sem acesso a uma biblioteca de referencia.

A internet, a meu ver, não substitui o texto impresso, mas de fato tem representado um imenso avanço na atualização de informações indispensáveis às atividades de ensino, pesquisa, serviço e até mesmo no tocante às atividades administrativas.

Acho que sofremos de 'information overload', isto é, excesso de informacao, com ênfase no quantitativo e esquecimento da qualidade, e que a internet está ampliando isto, junto com a tendencia de deshumanizacao do nosso trabalho. Por um acaso, fui programador e analista de sistemas no inicio dos anos 60, sai dessa apesar do bom salario e prestigio de uma profissao novissima, mas não consegui escapar da computadorizacao da minha vida.

Utilizo a internet e em particular os sites de informações -IBGE,DATASUS e Seade para desenvolver as aulas práticas das minhas disciplinas de graduação e pós graduação

Os pontos importantes foram abordados

Falta treinamento e incentivo compulsórios (+ avaliação) para os alunos assimilarem as novas tecnologias como parte do cotidiano da pós e de pesquisa! Ex.: os módulos de treinamento nas bases de dados da biblioteca deveriam ser atividades obrigatórias para TODOS os alunos!

Meu tema de estudo são as potencialidades das Tecnologias de Informação em Saúde na Gestão da Saúde, daí porque acabei tornando-me um usuário mais intensivo dos serviços da Internet.

A maior dificuldade é a lentidão

Sou professor de Informática Médica. Parece que vocês estão confundindo o uso da informática com o uso da Internet. Por exemplo, uso a Internet para coletar dados mas como posso usar a Internet para processar e analisar os dados? Poderia usar um computador remoto para realizar isso mas mesmo assim não estou usando a Internet para processamento.

A internet é dos avanços tecnológicos de maior impacto na divulgação e intercâmbio entre pesquisadoes

Não temos site de disciplina, nem das pesquisas pessoais, embora considere muito útil. Quanto a participar de ensino à distância, está entre minhas próximas prioridades.

Sobre o questionário, com opções de "melhorou" ou "piorou", não deixa muita liberdade para decidir. 
Acho que discussões orais, a busca em biblioteca não se atendo a "palavras-chaves", ouvir uma palestra conectado com outros ouvintes, sobre o tema são enriquecedores. Jogar um pouco de "prosa fora", o que não se faz na internet é muito bom para os processos de reflexão. Em suma: acho que a internet trouxe muito isolamento para os pesquisadores e que vem diminuindo muito a criatividade entre os alunos que tem uma fonte - seja qual for o assunto - inesgotável no computador.

A internet é uma ferramenta que auxilia na comunicação

Gostaria de poder dispor mais dos recursos da Internet, mas me falta tempo para aprender a lidar com isto

Pesquisa na internet não me faz muita falta pois posso usar os computadores aqui na USP para a consulta rápida e também tenho amigos e colgas, que são compulsivamente "internetianos", e que pesquisam para mim. Eu próprio, quando estou pesquisando um tema ou assunto, necessito ir às bibliotecas pertinentes, meu caso - FFLCH e FD/USP, Pós-graduação/PUCSP, IFCL e FD/UFMG - e nas estantes referentes aos assuntos e estantes correlatas, verificar o que existe e pode me interessar e que nem sempre consta da internet, Dedalus, e outros tais. Nada há pelo menos por enquanto - que substitua essa procura.

A Internet é para mim uma ajuda que se tornou imprescindível sobre tudo pelos contatos importantes e rápidos que posso fazer. Mas não tenho paciência diante das dificuldades para baixar textos ou navegar por centros de documentação.

Nao me considero padrao para a presente pesquisa porque embora tenha tido enorme resistencia para entrar nessa nova tecnologia, fui obrigado a entrar e e faço uso dela apenas naquilo que não tenho com "fugir" e nisso acabo algumas vezes achando muito bom!

Sou entusiasta do uso mais disseminado e intenso da INTERNET nas nossas atividades acadêmicas. Na minha área de atuação, é possível acesso a mais de 2000 periódicos de grande impacto, de modo completamente gratuito. Cada vez mais, periódicos estão disponibilizando versões full-text e isto é de uma importância extraordinária para a pesquisa e o ensino. Minhas sugestões são:

a) Há restrição de textos disponíveis na INTERNET para períodos mais recentes (freqüentemente após 1995). Algumas poucas revistas realizaram cópias digitalizadas de todo o acervo como a Biometrika e colocaram disponível (a partir de 1914), o que é uma iniciativa fantástica.

b) Penso que muitos professores se intimidam com este recurso e campanhas educativas deveriam ser realizadas;

c) Penso que laboratórios de informática amplamente capacitados deveriam ser instalados nas escolas de graduação de modo a permitir que alunos tenham amplo acesso. É impressionante como alunos de graduação se transformam quando percebem as perspectivas possíveis com o computador e a INTERNET;

d) Esperemos que a EAD venha também a se fazer realidade em breve em nossas universidades. 
Uso diariamente o e-mail porque coordeno uma pesquisa multicêntrica em 4 países (total de 11 centros) através basicamente do e-mail (administração e recebimento de arquivos). Faço muitos contatos com fabricantes de equipamentos, pesquisadores de outros países e uso muito o Medline. Sem a Internet suponho que o tempo dispendido para qualquer tarefa/resultado seria pelo menos 3 vezes maior.

Eu acho que a utilização para a graduação fica limitada em sala de aula por falta de equipamentos.

O mais importante para mim na utilzação da internet é o correio eletrônico (email) : para comunicação com colegas, participação em redes de discussão, troca de informações, acompanhamento de pesquisas, de trabalho de alunos, etc.

Faço uma avaliação otimista. É um recurso acumulativo, crescente em todos os sentidos. Crescente positivamente em termos da produção técnica informatica e crescente no uso adequado do instrumento

Para quem sabe das coisas é fácil separar mais ou menos rapidamente o que é bom do ruím. Para quem ainda não sabe, tem que tomar muito cuidado, pois há muita porcaria mesmo.

Assim que findar esta euforia pelo uso deste interessante veículo de comunicação, seu uso será otimizado em prol de ampliar as facilidades e evitar o consumo do tempo desnecessário imposto pelo aumento da demanda. heterogeneidade das linguagens disponíveis, exigindo conhecimento sobre detalhes da informática que poderiam ser suprimidos para facilitar a utilização do usuário.

Os maiores problemas que tenho encontrado na verdade está nos provedores e especialmente a dificuldade de alunos possuírem o recurso de informática em casa, uma vez que a maioria não possue poder aquisitivo para adquirir uma máquina ou manter o pagamento mensal de utilização de internet.

Dois usos da internet na pesquisa tem sido fundamentais. O primeiro é o uso de páginais institucionais como fonte para analise de politicas. A segunda é a utilização de entrevista por meio eletronico em pesquisas, que permite alcançar pessoas que jamais poderiamos encontrar. minha experiencia com ambos os procedimentos tem sido muito positiva, mesmo exigindo cuidados metodologicos.

Entendo que esta deverá ser uma critica comum, os problemas de acesso continuo e rapido ainda são muito expressivos. no nosso meio (Brasil), esta ainda é uma questão fundamental a ser solucionada. Referindo a falta de infra-estrutura de redes no Brasil

O preço altissimo dos computadores portáteis tem sido um elemento de frustação no tocante ao meu uso da internet. As universidades deveriam facilitar a aquisição de laptops

A internet veio auxiliar as minhas atividades, porem entendo que não devemos ficar completamente dependentes do uso dessa recnologia. Apesar de dispor de recursos tecnicos com certa facilidade, ainda prefiro e priorizo o ensino nos moldes "arcaicos" com a presença do aluno/professor nas aulas 
Pelo pouco tempo de uso do computador apenas estou iniciando-me na internet, principalmente enviando e recebendo e.mail, corrigindo trabalhos dos alunos, analisando dissertações e projetos de pesquisa e dando pareceres, o que aliado ao pouco conhecimento das facilidades da internet, nao consigo explorar sua potencialidade.

Facilitou grandemente meu trabalho academico bem como de meus orientandos

A internet é boa para dar uma visão geral da situação em pesquisa e para comunicação rápida. Mas há necessidaade de pesquisas locais e nem todos estão ligados na rede.

Considero que a Internet ampliou, em muito, as facilidades para o melhor desenvolvimento das minhas atividades acadêmico-científicas pois permitiu maior acesso e agilidade a informações de importância para muitas das minhas atividades.

Como aposentado, o questionario ficou meio prejudicado. Entendo que o uso da Internet ficará cada vez mais importante e poderá reduzir muito o tempo estipulado para a graduação e pós-graduação dos alunos. Eventualmente poderá ir substituindo a atual figura do professor.

A comunidade cientifica deveria discutir como poder pre-classificar alguns sites quanto a credibilidade. Como nao existe a figura do editor e comunicacao cientifica, qualquer pesquisa ou trabalho com conteúdos e metodologia sofriveis encontram-se na internet. É muito trabalho "garimpar" o que realmente vale a pena.

Internet não substitui uma biblioteca. Acredito que tenha sido uma das primeiras pessoas a respondê-lo. Para mim seria muito importante saber o motivo de ter respondido novamente.

Formulário por e.mail. Respondi quando enviado pela $1^{a}$ vez

Item 15 - Boletim Interno ENSP, Boletim Interno FIOCRUZ, LIsta Departamento e Listas Temas Discussão

Excesso de informação.... (mas de qualidade superficial e duvidosa)

Embora eu não possa negar as facilidades oferecidas pela internet, num mundo tão cheio de informações, as pessoas, alunos incluídos, tendem a se acomodar com as informações superficiais que são oferecidas e a??? nas armadilhas de achar que já fiseram as pesquisas exaustivas sobre os assuntos que pesquisam. (e ficam mais ainda!) "preguiçosos", no lento trabalho da construção de tais conhecimentos.

Quanto aos formulários por e.mail: só respondo mensagens que tenham relação direta com meus interesses, mas na insistência tem que ser considerada uma virtude. Dai, respondo agora. Além do mais tenho uma nítida preferência pela escrita impressa. 
Projetor: Gostaria mais nunca está disponível na Faculdade. Computador portátil... O que eu uso é de minha propriedade. Computador individual... que consegui com a FAPESP, a instituição não fornece nem tinta a maioria das vezes . Treinamentos.... no final nunca consegui aprender nada. o que eu sei fazer foi batendo a cabeça sozinha ou com os meus filhos. Biblioteca .... não tenho tempo de ir, infelizmente! mesmo ficando três períodos na Faculdade.

Falta de tempo para usar internet.... Principalmente

Gostaria de ficar mais tempo usando o que é difícil com o acúmulo de atividades que realizo. Tenho um pouco de dificuldades em usar. Geralmente, as atividades que realizo não podem ser feitas pelo computador e quando podem, os programas são complicados até para quem entende: ex: projeto ciência e tecnologia do ministério, curriculum lattes, etc. Ainda é um veículo eletista!

Por e.mail. Não abri seus e... - Porém respondi e enviei em seguida. mesmo teno acabado o prazo.

Sempre que possível tenho usado. Embora sem ter muito conhecimento de informática, muitas vezes preciso de colaboradores. No entanto, ainda uso muito mais livros e revistas indexadas.

É um instrumento muito útil como facilitador na montagem de aula ou para viabilizar material e/ou bibliografias na construção de aulas e artigos.

Nunca utilizei a divulgação por meio eletrônico, mas gostaria. Alias uma vez sim, através da Biblioteca. 